\title{
La ^̌uy mediadora: ornitología, magia amorosa, mitología y teología caldaico-neoplatónica ${ }^{1}$
}

\author{
Álvaro FernÁNDEZ FeRnÁNDEZ \\ Universidad de Granada \\ alvarofdezfdez@gmail.com
}

Recibido: 29-11-2013

Aceptado: 19-01-2014

\section{RESUMEN}

En griego $\iota_{u} y \xi$ designó originariamente un pájaro: el torcecuello. Los rasgos fisonómicos y el comportamiento del ave debieron de propiciar la creencia de que tenía un poder mágico y de que, atada en cruz a una rueda por una hechicera, habría de atraer a la persona amada. Los mitógrafos helenísticos, aprovechando el asunto del torcecuello como «pájaro de Afrodita», elaboraron dos mitos acerca de la metamorfosis de Iunx en pájaro. Desde los inicios de la época clásica la voz î́vүł fue adquiriendo nuevos sentidos, según parece, por metáfora, metonimia o sinécdoque, significados que no siempre se muestran del todo claros en los textos: 'rueda mágica', 'conjuro amoroso', 'deseo', 'encanto', etc. En pasajes heterogéneos de contenido religioso la voz îuү normalmente a un tipo de mediación entre dos mundos, el divino y el humano. La especulación filosófica sobre las îuүyę como entidades mediadoras o demónicas alcanzó su máxima expresión entre los neoplatónicos que interpretaron los Oráculos caldeos en clave teológica.

Palabras clave: torcecuello, léxico griego, magia, mitología, Oráculos caldeos, teúrgia, neoplatonismo.

\begin{abstract}
The Greek term ' $\iota \gamma \xi$ was originally designated for a bird: the wryneck. The physical features and behaviour of the bird may have given birth to the belief that it had magical powers and that, cross tied to a wheel by a sorceress, it would attract a beloved person. The Hellenistic mythographers exploited the theme of the wryneck as «bird of Aphrodite» and related two myths about the metamorphosis of Iunx into a bird. From the beginnings of the Classical Period the term "ivy was acquiring new meanings to be derived, it seems, by metaphor, metonymy or synecdoche, meanings that are not always perfectly clear in the texts: 'magic wheel', 'love spell', 'desire', 'charm', etc. In heterogeneous passages of religious content the term îuү乡 normally alludes to a sort of mediation between two worlds, the divine and the human. The philosophical speculation about the "uүyes as intermediaries or demonic entities reached its peak within the Neoplatonists who interpreted the Chaldean Oracles in a theological way.
\end{abstract}

Keywords: wryneck, Greek vocabulary, magic, mythology, Chaldean Oracles, theurgy, neoplatonism.

${ }^{1}$ Trabajo realizado en el grupo de investigación Hermekate (HUM-404: «Tradición y pervivencia de la cultura griega»), cofinanciado por la Universidad de Granada y la Junta de Andalucía. Se presentó un esbozo del mismo en el «II Congreso internacional de estudios clásicos en México», celebrado en la Universidad Nacional Autónoma de México del 8 al 12 de septiembre de 2008. 
El sustantivo femenino îuy informa escuetamente el Léxico sobre los espiritus de las palabras (s. XI), un epítome bizantino elaborado a partir de tratados ortográficos debidos, entre otros gramáticos, a Trifón de Alejandría, Jorge Querobosco y un tal Teodorito: 'ívy refería bien a un ave bien a un instrumento ${ }^{2}$. Más elocuente es la noticia anterior de la enciclopedia Suda (s. $\mathrm{x}$ ), donde en realidad se reproducen las observaciones ya anotadas en el Compendio léxico (s. Ix) del patriarca Focio:

Existe también un pequeño artefacto (ópyóviov) llamado iunx, al que las he-

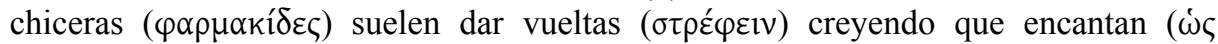

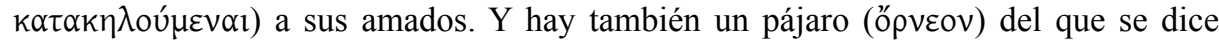

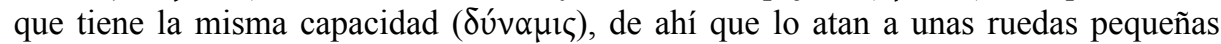

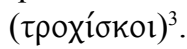

En la literatura griega la descripción más detallada del animal mencionado, y que nos permite identificarlo con bastante certeza con el torcecuello euroasiático (Jynx torquilla Linnaeus, 1758), se lee en la Investigación sobre los animales de Aristóteles ${ }^{4}$ :

Unas pocas aves tienen dos dedos hacia delante y dos hacia atrás ${ }^{5}$, como el denominado torcecuello (ívy̧). Éste es algo mayor que un pinzón ${ }^{6}$, de aspecto moteado

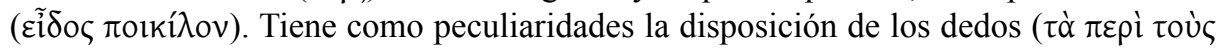

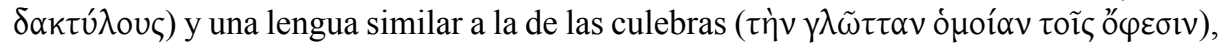
pues se extiende hasta cuatro dedos de largo y luego se retrae sobre sí misma ${ }^{7}$. Ade-

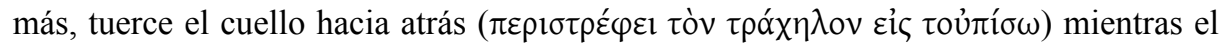
resto de su cuerpo permanece inmóvil, como una culebra. Tiene uñas grandes (ővuxaৎ

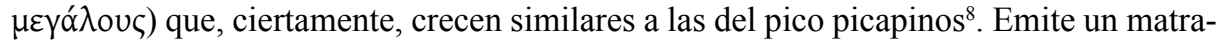

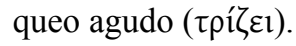

${ }^{2}$ Lex. de spirit. 230, p. 206, 7-8 Valckenaer.

${ }^{3}$ Sud., 1 759, 3-6 Adler; Phot., Lex. I, p. 118, 14-18 Porson = p. 300, 18-21 Naber. Cf. Laeu., fr. 27, p. 148 Blänsdorf (FPR, fr. 27, p. 292 Baehrens = fr. 10, p. 78 Mueller): Philtra omnia undique eruunt: / antipathes illud quaeritur / trochisci, iunges, taeniae, / radiculae, herbae, surculi, / saurae inlices, bicodulae / hinnientium dulcedines.

${ }^{4}$ Arist., HA II, 12, 504a, 11-19 Louis.

${ }^{5}$ Aristóteles también constata el rasgo de la zigodactilia en $P A$ IV 695a, 24 Louis.

${ }^{6}$ El torcecuello mide 16 ó $17 \mathrm{~cm}$ de largo, tiene una envergadura de unos 25 , y pesa entre 30 y $45 \mathrm{~g}$.

${ }^{7} \mathrm{Su}$ lengua mide unos $5 \mathrm{~cm}$, llegando a sobresalir más o menos la mitad y a extenderse cinco veces el largo del pico (Morris, 1852: 3; González, Gómez \& Muñoz, 2002: 12; Perrins, 1987: 17).

${ }^{8}$ Sigo la lectura koגıó (Dendrocopos major) de J. G. Schneider (Aristotelis De animalibus historiae libri X, Lipsiae, 1811: vol. I, 61); cf. Arnott, s.v. «Kolios», «Kolophōn» (2007: 157, 158). P. Louis (Aristote: Histoire des animaux, Paris, 1964: vol. I, 53) lee koגoı́́, 'grajilla' (Corvus monedula; cf. Thompson, 1895: 89-90), graculus en Plinio [texto cit. n. 16]; J. Pallí Bonet (Aristóteles: Investigación sobre los animales, Madrid, 1992: 108) traduce koגoó y J. Vara Donado (Torrejón de Ardoz, 1990: 114) por 'corneja' (Corvus corone); cf. Foufopoulus \& Litinas (2005) y Arnott, s.v. «Koloios» (2007: 156-158). L. Dittmeyer (Aristotelis De animalibus historiae,

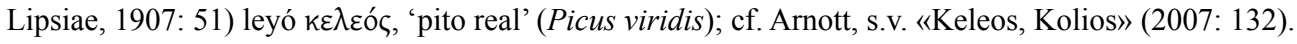


Para mayor luz añadiré la descripción que se hace en los discursos Dia, y noche de Madrid (1663) del escritor español Francisco Santos:

Vn pajaro ay bien conocido, a quien llaman Torcecuellos: a efte le dio naturaleza la lengua diferente, que a otros pajaros, pues es delgada como vn hilo, y larga. Efte, con particular inftinto, bufca los hormigueros mas copiofos, y alli fe echa, facando, y tendiendo la lengua a la puerta de aquellas ambiciofas afanadoras: ellas codiciofas del fabor de la carne, fe enlaçan en ella; y en eftando toda cubierta de hormigas, abre el pico, y fepulta en fu feno todas aquellas viuientes, metiendo dentro la lengua, cargada de hormigas, como herizo de madroños, ò mançanas?

Aristóteles nos ofrece «a full and accurate description ${ }^{10}$ del pájaro. Con una salvedad: el tamaño de las uñas parece un tanto exagerado. Aunque son relativamente 'grandes', podría referirse a que son más bien 'fuertes, duras': le permiten sujetarse a los troncos como un ave trepadora. Como en sus uñas el torcecuello se parece más a los carpinteros — también zigodáctilos - que a los córvidos, me ha parecido más acertada la lectura ko $\lambda$ ıó ('pico picapinos'). Su semejanza con la serpiente se aprecia en otro rasgo físico: "característica primordial de su plumaje son las dos líneas longitudinales oscuras, que desde el píleo recorren cuello y dorso. Estas líneas pueden darle cierto aspecto de culebra visto desde arriba» ${ }^{11}$. Píndaro también debió de percibir un parecido entre ambos animales a los que describe igualmente como $\pi$ пokílo ${ }^{12}$ : en el caso del torcecuello, juzga Detienne, el adjetivo podría aludir, más que al plumaje variopinto ${ }^{13}$, «to the ever-changing sheen associated with the mobility of the wryneck» ${ }^{14}$, que al desplazarse entre la hierba en busca de alimento recuerda por instantes a una culebra. La opinión de Detienne explicaría por qué a Ateneo le pareció que su plumaje tiene un color brillante como de anguila (por ende, el pájaro se habría camuflado perfectamente sobre un tronco de pino laricio) ${ }^{15}$. Plinio el Viejo y dos escolios parafrasearon la descripción aristotélica, sin aportar nuevos pormenores ${ }^{16}$.

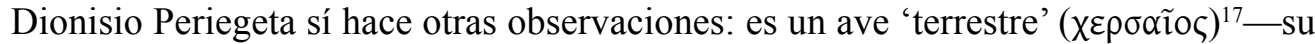
hábitat primordial es el bosque-, que despliega la lengua como si fuera un sedal con que pescar hormigas, y que mueve sin cesar el cuello como solían hacer, en frenéticas

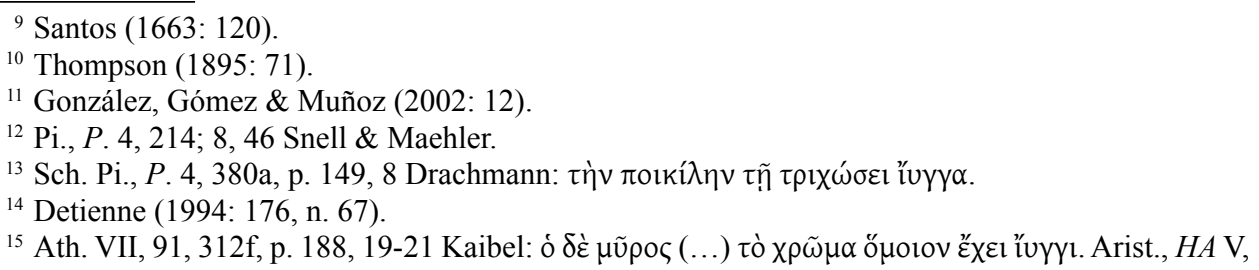

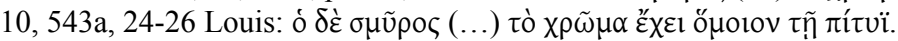

${ }^{16}$ Plin., NH XI, 47 (107), 256 Mayhoff: Iynx sola utrimque binos habet. Eadem linguam serpentium similem in magnam longitudinem porrigit, collum circumagit in auersam se. Ungues ei grandes ceu graculis. Sch. Pi., P. 4, 381a, p. 149, 12-15 Drachmann (cf. Sch. Lyc., Alex. 310, p. 126, 9-12 Scheer):

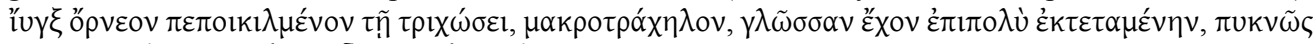

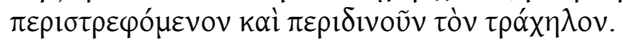

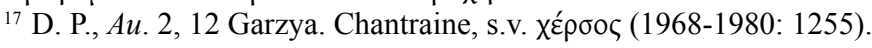


danzas eróticas, los participantes en los ritos de Rea ${ }^{18}$. La creencia bereber del centro de Marruecos según la cual el torcecuello se hace el muerto para engañar a las hormigas, atraerlas hacia su pico y engullirlas, en opinión de Bynon, podría remontar a la Grecia antigua ${ }^{19}$.

A Pollard le parece significativo el hecho de que Aristófanes no haya mencionado el torcecuello en Aves, la comedia donde desfila multitud de pájaros ${ }^{20}$; no parece mera coincidencia que tampoco se haya documentado en el ágora de Atenas ${ }^{21}$. Si el torcecuello fue en la Grecia antigua tan difícil de ver como ya lo era a mediados del siglo XIX o el siglo pasado ${ }^{22}$, debió de ser un ave, más que rara, poco conocida. A su vez, Friedrich sugirió que en la Odisea se alude a él: la imagen de la rauda nave que

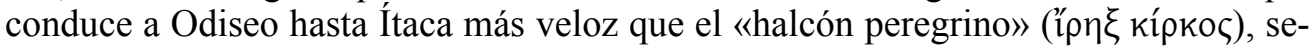
gún cree, podría estar inspirada en un torcecuello ${ }^{23}$; pero, aunque éste recorre largas distancias migratorias, al volar de rama en rama - esto es, cuando en realidad podía ser observado - lo hace con lentitud relativa y trazando trayectorias onduladas ${ }^{24}$.

En Sobre las peculiaridades de los animales Eliano (s. II-III d.C.) caracterizó al torcecuello por su habilidad para responder al sonido de la 'flauta travesera' ( $\pi \lambda \alpha$ '́ $ү 10 \varsigma$ $\alpha \hat{u} \lambda o ́ \varsigma)^{25}$. Sin embargo, no hemos de inferir por ello que el torcecuello es un pájaro propiamente canoro: su canto consiste en un matraqueo agudo, nasal, monocorde, acelerado y relativamente prolongado, que usa como reclamo y para marcar su territorio en período reproductivo; a esta forma de cantar debe de referirse Aristóteles con la voz $\tau \rho \hat{\imath} \zeta \omega$, 'utter a shrill cry' (LSJ) a la manera de un polluelo, un murciélago

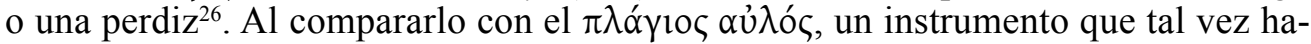
cía «a soft wind-like sound» ${ }^{27}$, Eliano debe de estar aludiendo al soplo silbante que hace el torcecuello cuando, desde el interior del nido, nota la presencia cercana de un eventual intruso. Los lexicógrafos y escoliastas bizantinos, no obstante, debie-

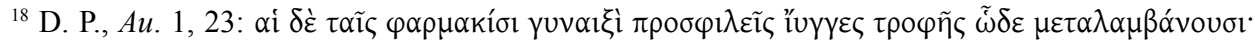

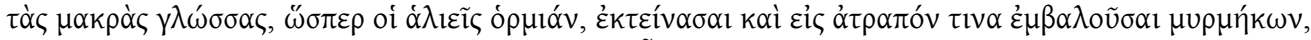

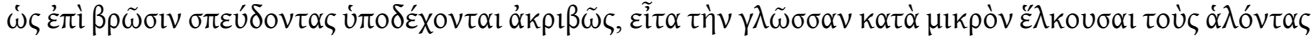

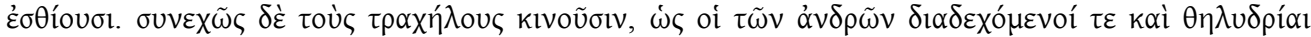

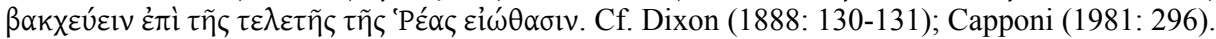

${ }^{19}$ Bynon (1987: 156-157).

${ }^{20}$ Pollard (1997: 48).

${ }^{21}$ Cf. Lamberton \& Rotroff (1985).

${ }^{22}$ Douglas (1927: 93); Arnott (2007: 118). En Grecia hoy día el torcecuello reside permanentemente en las áreas correspondientes a las antiguas Córcira (zona sur) y Acarnania (centro); cría en Macedonia, Córcira (norte) y Tesalia (norte); en la estación no reproductiva habita Acarnania (sur), Etolia, Lócride, Fócide, Beocia, Ática, Peloponeso, Eubea, Andros, Paros, Naxos, Creta (norte y este) y Rodas (http:// www.iucnredlist.org/details/22680683/0). Cf. Gilbert (2001: 68).

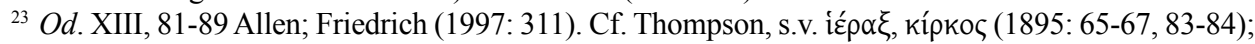
Arnott, s.v. «Hierax, irēx», «Kirkos» (2007: 99-102, 148).

${ }^{24}$ Morris (1852: 3); Dixon (1888: 130); Perrins (1987: 146, 237).

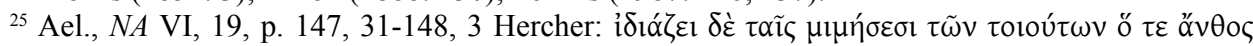

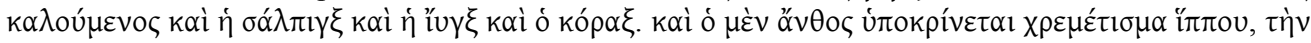

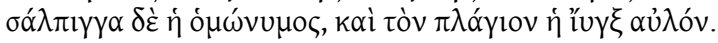
1138).

${ }^{26}$ El torcecuello emite «a shrill call» (Arnott, 2007: 118). Cf. Chantraine, s.v. $\tau p i ́ \zeta \omega ~(1968-1980$ :

${ }^{27}$ West (1992: 113). 
ron de creer en la capacidad musical del torcecuello, pues registran los significados

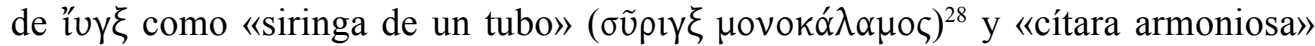

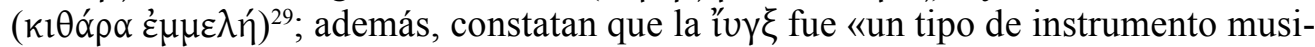

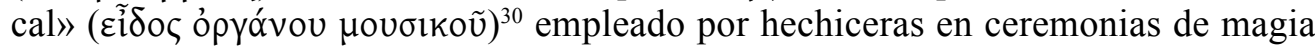
amorosa.

En la actualidad nombramos el pájaro en referencia al rasgo que, desde nuestra perspectiva cultural, resulta el más distintivo de la especie: tuerce el cuello (Wende-

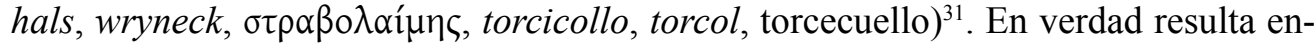
tretenido mirar cómo uno de ellos, gracias a su vértebra heterocélica, balancea, tuerce, dobla, encoge y extiende el cuello, cual contorsionista circense o gimnasta que realiza estiramientos, a la vez que eriza las plumas del píleo: el pájaro adopta esta conducta inconfundible cuando se alarma (si lo sorprenden en el nido, si es apresado en mano) o supuestamente, lo que Capponi niega que suceda ${ }^{32}$, cuando corteja a su pareja ${ }^{33}$. En ocasiones, ciertamente, los movimientos del cuello evocan el vaivén amenazante de una serpiente que se balancea erguida. Sin embargo, hubo de ser su voz el rasgo que primero llamó la atención de los griegos antiguos: al habitar en áreas de vegetación arbórea y disponer de un plumaje que se mimetiza con la corteza de los árboles, el torcecuello «suele ser un ave desconocida, incluso para los habitantes de la zona que ocupa, quienes no obstante sí identifican su peculiar canto» ${ }^{34}$.

En sus comentarios homéricos Eustacio de Tesalónica (s. XII) asume que el sustantivo ${ }^{\prime} u \gamma \xi$ deriva del verbo $\mathfrak{i}\left\langle{ }^{\prime} \omega^{35}\right.$. El nombre del ave, onomatopéyico, aludiría a un sonido específico: iú $\zeta \omega$ se ha definido como "'shout, yell', in order to scare beasts» (LSJ). Para defender el nido de intrusos y ahuyentar a las alimañas, según parece, el torcecuello resopla «like the sizzling of a bottle of mineral water being shaken but not quite closed $\gg{ }^{36}$. El silbo serpentino dio pie a que el ave fuera conocida en época reciente con el nombre de 'snake-bird' ${ }^{37}$ en localidades del Reino Unido. En opinión de Böhr ${ }^{38}$, Aristóteles estaría aludiendo a este tipo de sonido disuasorio (' $h i s s i n g$ ') al decir que el torcecuello $\tau \rho \hat{\zeta} \zeta \varepsilon l$; contrariamente, puede que Aristóteles pensara más bien en el canto del pájaro, el vivaz matraqueo que puede oírse a distancia.

${ }^{28}$ Lex. Seg. 1, p. 265, 21 Bekker; Et. Gud. 1, col. 285, 11 Sturz; EM, p. 480, 2 Gaisford. Según West (1992: 213) «the syrinx was used to imitate the hisses of the expiring snake».

${ }^{29}$ Sch. Lyc., Alex. 310, p. 126, 22-23 Scheer; Sch. Aristid. 182, 11, p. 307, 20-21 Dindorf.

${ }^{30}$ Sch. Opp., H. I, 565, p. 291, 28-29 Bussemaker.

${ }^{31}$ En Gramática castellana III, 6 (Salamanca, 1492) Nebrija se sirve del término 'torcecuello' para ejemplificar los compuestos nominales-verbales.

${ }^{32}$ Capponi (1981: 296-297).

${ }^{33}$ Burton (2002: 2996-2997).

${ }^{34}$ González, Gómez \& Muñoz (2002: 12, 18). Cf. Dixon (1888: 129-130); Cortés \& Domínguez (1997: 40).

${ }^{35}$ Eust., In Il., P v. 66, p. 17, 5-6 Valk; In Od., O v. 162, p. 95, 46-96, 1 Stallbaum. Cf. Lex. de spirit. 230, p. 206, 7-8 Valckenaer.

${ }^{36}$ Böhr (1997: 112). «When alarmed it utters a sharp and oft-repeated metallic clicking note» (Dixon, 1888: 130).

${ }^{37}$ Morris (1852: 3); Dixon (1888: 133); Lydekker (1894-1895: 568).

${ }^{38}$ Böhr (1997: 112). 
El término $\iota u y \xi$, en otro tiempo considerado «of foreign and unknown origin» $»^{39}$, hoy se juzga, por la prenasalización, un préstamo pre-griego ${ }^{40}$. Las voces afines iuүń, iuүuós e iú̧ $\omega$, opinó Pokorny, derivan de una raíz IE *iū́- que significa 'sorpresa', iû́ en griego, presente acaso en iavoĩ, loú e iubilo ${ }^{41}$. A su vez, Chantraine sospecha que la etimología de Eustacio podría ser ficticia, de cuño popular; recuerda que ǐuү乡 es una formación expresiva similar a otras en $-v \gamma \xi$ o $-\imath \gamma \xi$ que proporcionan nombres de aves e instrumentos musicales; y emparenta $i v ́ \zeta \omega$ con la onomatopeya $i u^{42}$. A la

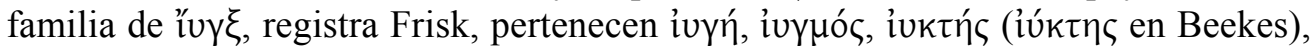

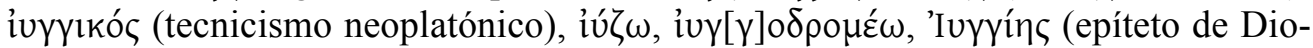
niso) e 'Iuүyíoc (en Beekes, 'Iúyүioc: mes tesalio usado a principios del siglo II en Kierion y Skotoussa ${ }^{43}$, y en el que se celebraba un festival en honor del dios $)^{44}$; Chan-

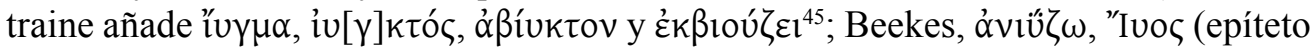

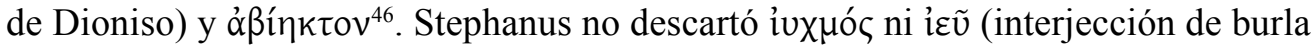
e ironía) ${ }^{47}$. A ellas cabe sumar iuyríov (especie de gorrión, o pájaro pequeño, del Ática, comestible) ${ }^{48}$ e iuypoí ('lamentos' de mujer, o plañidera) ${ }^{49}$, de no ser un error

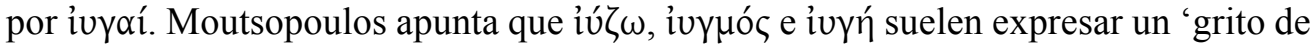
pena o dolor', y alguna vez 'de alegría' ${ }^{50}$. Con íuyүoৎ el gramático Sofronio (s. IX) ejemplificó cuál es la terminación de genitivo de los infrecuentes nominativos en $-\gamma \xi^{51}$. Eustacio transmite la variante de nominativo $\iota^{\prime} v \xi$, que justifica por la pérdida de la gamma ${ }^{52}$.

${ }^{39}$ Thompson (1895: 71), seguido por Böhr (1997: 112).

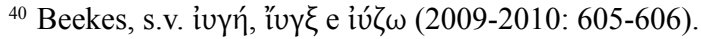

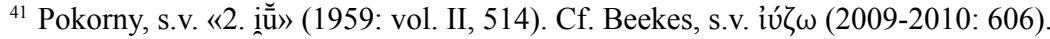

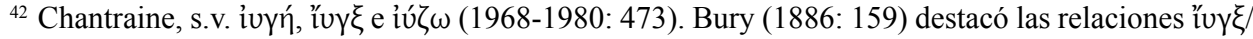

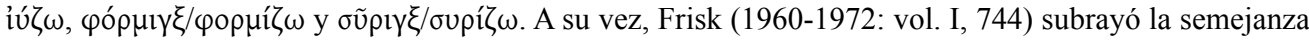
formal entre $i v \gamma \xi$ ('torcecuello'), $\pi \tilde{\omega} u \gamma \xi$ ('garza'), $\sigma \tau \rho i ́ \gamma \xi$ ('lechuza') y $\sigma \tilde{v} \rho \imath \gamma \xi$ ('siringa'). Pueden sumar-

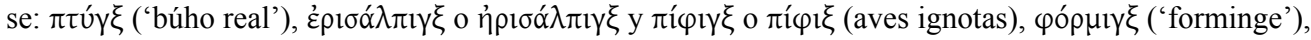

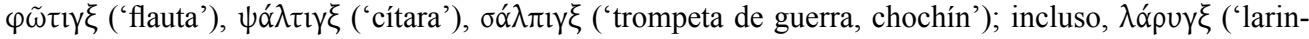

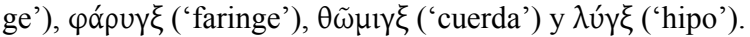

${ }^{43}$ Graninger (2011: 96-97).

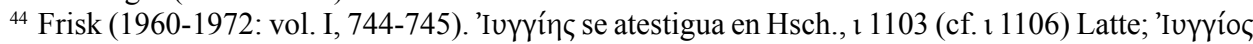
en SEG XV, 370 e IThess. 1, 15 Decourt; ì

${ }^{45}$ Las voces se documentan en: A., F**46a, 17 Radt = 41D, fr. 464, 17 Mette; Hsch., 1 1109, $\alpha$ 128,

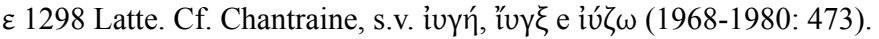

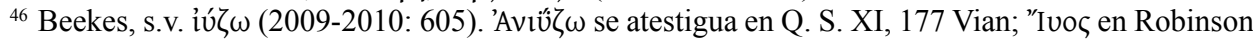
(1927: 49) = SEG VI, 398, así como en SEG XXXIV, 1395.

${ }^{47}$ Stephanus (1572: vol. I, col. 1943f-1946h): iuxuós se atestigua en Hsch., 1 1114; i̇̃̃ en Ar., $V .1335$ MacDowell y en Sch. Ar., $V .1335$ Koster.

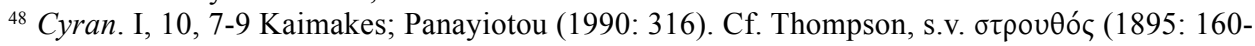
162).

${ }^{49}$ Phot., Lex. I, p. 118, 9 Porson (p. 300, 14 Naber: iuyoí; cf. Lex. Seg. 1, p. 267, 12 Bekker: iuyoí).

${ }^{50}$ Moutsopoulos (1990: 292, n. 42-44).

${ }^{51}$ Sophr., Excerpta 29, p. 400, 10-11 Hilgard.

${ }^{52}$ Eust., In Od., T v. 480, p. 213, 41-42 Stallbaum. En Diccionario griego-español, Barcelona, 1983: 377 F. Sebastián Yarza identifica la ı̌u como el 'aguzanieves' (Motacilla alba). 


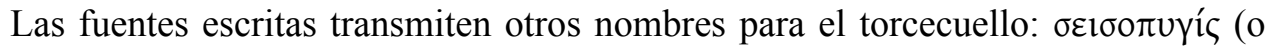

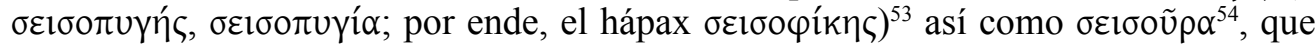

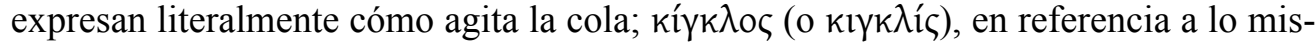
$\mathrm{mo}^{55}$; kıрvaio $\varsigma^{56}$, cuyo lexema en principio significaría 'mezcla' (¿la del plumaje va-

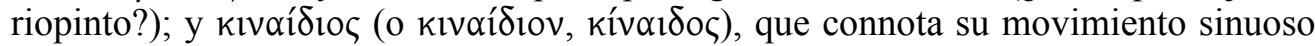
e impúdico, como si fuera un bailarín obsceno que «menea» con desfachatez «las vergüenzas $\rangle^{57}$. Hesíodo, con su consejo a los hombres de que no se dejen engatusar

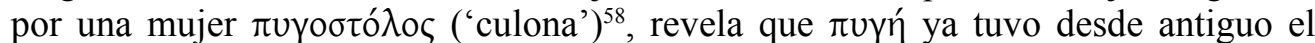
doble sentido 'cola, nalgas'. Con todo, puede que al pájaro se le hayan dado los nom-

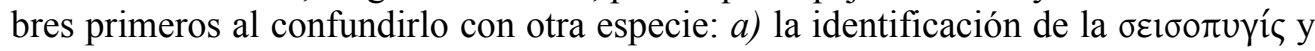
el kí $\gamma \kappa \lambda$ os con el torcecuello proviene de fuentes bizantinas y no se atestigua en la Antigüedad; b) el torcecuello, según he observado, no mueve su cola ni «en todo momento» ni «en todas partes» — como afirman los escolios—-, aunque sí la despliega en

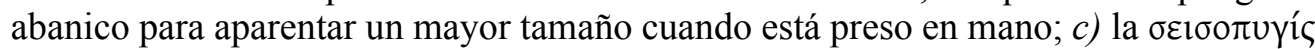
y el kí $k \lambda$ o deben de pertenecer al género de las lavanderas (Motacillae), aves que se caracterizan por sacudir la cola con insistencia ${ }^{59}$. No obstante, Capponi sostiene que "̂́vł no designó una sola especie (Jynx torquilla) ni un único género (Jynx) de aves, sino diversos pájaros que incluso pertenecían a familias distintas (Picidae, Motacillidae $)^{60}$. En opinión de Thompson ǐvv $\xi$ e ítu torcecuello ${ }^{61}$. Arnott, quien explica el primero por una metátesis $*^{\prime \prime} v v \xi>$ ǐv $v \xi$, añade el sinónimo $\gamma \lambda \omega \tau \tau i ́ \varsigma$ ('tongue-bird') ${ }^{62}$, en alusión a esa otra característica anatómica del torcecuello que ya subrayó Aristóteles.

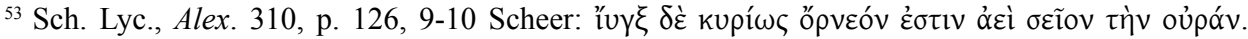

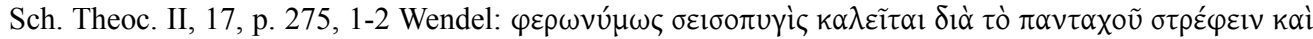

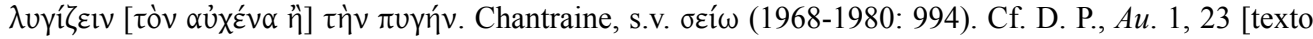
cit. n. 18]; Sud., 1760 Adler; Et. Gud. 1, col. 285, 12 Sturz; Zonar., Lex., col. 1132, 15-16 Tittmann; EM,

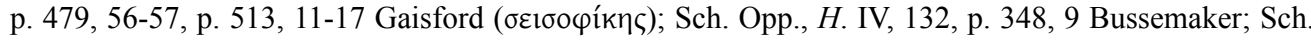
Aristid. 182, 11, p. 307, 21-22 Dindorf.

${ }^{54}$ Sch. Opp., H. I, 565, p. 291, 27-28. Stephanus (1572: vol. II, col. 1541c).

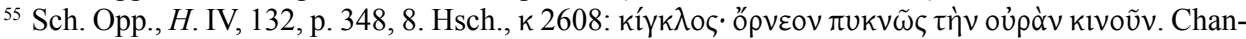

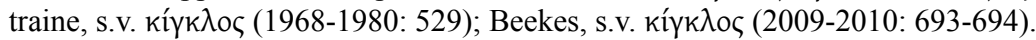

${ }^{56}$ Sch. Opp., H. I, 565, p. 291, 27-28 Bussemaker. Cf. Stephanus (1572: vol. II, col. 141c-g).

${ }^{57}$ Cyran. I, 10, 4 Kaimakes; Hsch., 1111 [texto cit. n. 110], к 2715 Latte; Sch. Pl., Grg. 494 e, p. 158 Greene; Sch. Theoc. II, 17, p. 274, 15 Wendel; Phot., Lex. I, p. 118, 13-14 Porson; Sud., 1 759, 3. Cf. Et.

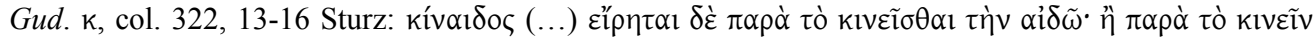

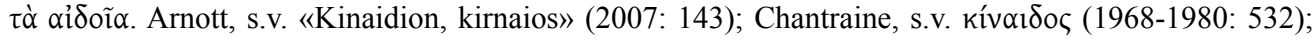

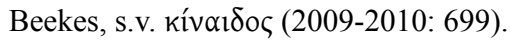

${ }^{58}$ Hes., Op. 373-374 Mazon. Cf. Beekes, s.v. זuүń (2009-2010: 1253).

${ }^{59}$ Varro, LL V, 76, p. 24, 18-19 Goetz \& Schoell: Motacilla (...) semper mouet caudam. Bury (1886: 158, n. 1); Thompson (1895: 81-82, 153); Arnott, s.v. «Kinklos» (2007: 144-145).

${ }^{60}$ Capponi (1981: 293-295).

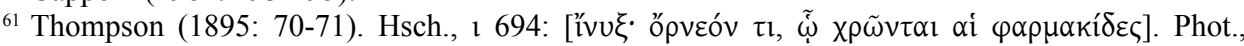
Lex. I, p. 118, 6 Porson (Sud., 154 Adler; Syn. Lex. 1 148, p. 279 Cunningham = Lex. Seg. 1, p. 264, 22

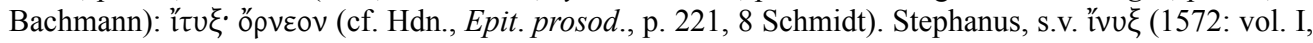

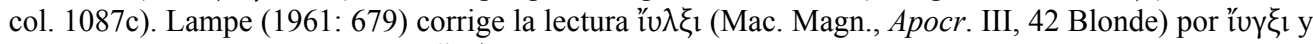
documenta la variante manuscrita îv $\xi_{\text {l. }}$.

${ }^{62}$ Arnott, s.v. «Glōttis» (2007: 86). La fuente es Arist., HA VIII, 12, 597b Louis. 
Según una conjetura decimonónica el término ívył habría designado en su origen «a song to the moon-goddes ' $\left.\mathrm{I} \omega{ }^{\prime}\right)^{63}$. Bury, el responsable de la misma, tras comparar

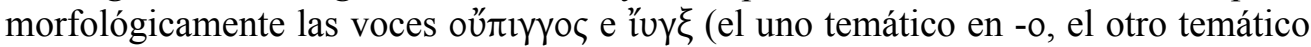
con nominativo en sigma), argumentó como sigue: en Tesalia el oǘrıүүoৎ fue un himno consagrado a la Luna, según corrobora Calímaco al invocar a Ártemis (o sea, a la

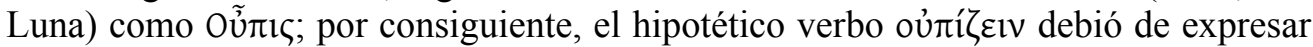

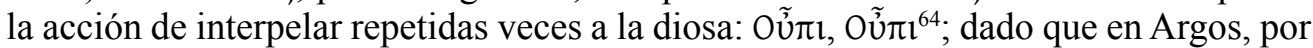
otra parte, 'I $\omega$ designó a la Luna ${ }^{65}$, el verbo iúlzıv hubo de significar la acción de apelar

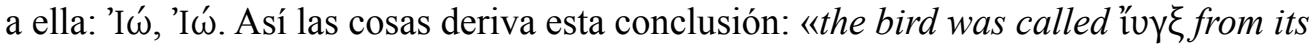

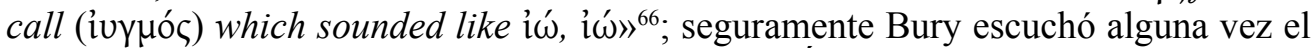
canto del torcecuello en las campiñas de Inglaterra. Él cita otros testimonios literarios

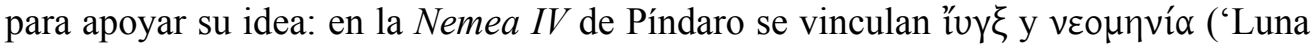
nueva'); en los dos estribillos del Idilio II de Teócrito aparecen sendas invocaciones

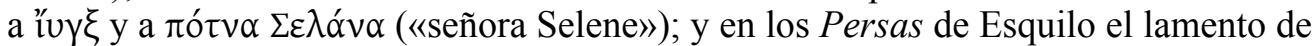

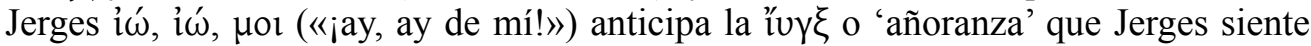
más tarde por sus compañeros muertos en batalla ${ }^{67}$. En cuanto al testimonio de Esquilo, Bury pareciera asumir que la interjección îu (según el LSJ se usa «in invoking aid», o como expresión de 'grief, suffering') también se originó en la invocación a la diosa Luna. Sin embargo, otros investigadores que han reparado en la tesis no creen que exista relación alguna, mucho menos etimológica, entre "̂́uł e 'Ió-Luna ${ }^{68}$, como tampoco entre los homófonos î́ (interjección) e 'Í́ (antropónimo) ${ }^{69}$.

Los primeros testimonios de la literatura clásica sobre el torcecuello se hallan en Píndaro: en uno de sus trenos, hoy fragmentario, el término $\iota^{\prime} u \gamma \xi$ aparece junto a otro de lectura incierta $\tau[\rho]$ ]ọọ que refiere según se cree a la rueda ${ }^{70}$. También se debe al poeta tebano la composición que daría fama a la îuүł como «pájaro de Afrodita» usado por las brujas en sus $\varphi$ í $\lambda \tau \rho \alpha$ o 'remedios de amor' ${ }^{71}$ : la Pítica IV (462 a.C.), donde recrea el asunto mítico de los amores entre Jasón y Medea. En esta oda el torcecuello

${ }^{63}$ Bury (1886: 160), seguido por Tavenner (1933: 110, n. 7).

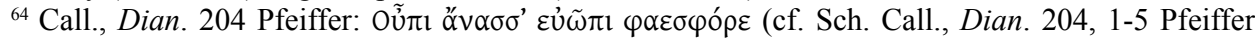
$=E M$, p. 641, 54-642, 3 Gaisford). El oümıүyoৎ se asocia a Ártemis (Ath. XIV, 10, 619b, p. 365, 14-15 Kaibel; Poll. I, 38 Bethe; Thdt., Affect. IV, 66, 11 Canivet; Psel., Oratoria 35, 165-166 Littlewood); y junto con Ártemis a la ciudad de Trecén (Sch. A.R. 972a, p. 85, 8-9 Wendel). Oũ̃ıৎ fue a su vez una divinidad virgen de Trecén (Hsch., $\varepsilon 7316$ Latte) y apelativo de Tritogenia (IGUR III, 1155, 61); cf.

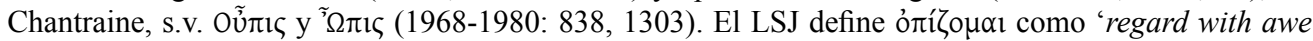
and dread'.

${ }^{65}$ Hdn. Gr. III/1, p. 348, 1 Lentz (Eust., In D. P. 92, GGM II, p. 235, 21-22 Müller): 'İ̀ үà

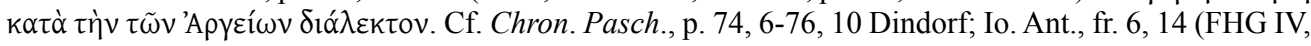
p. 544) Müller; Sud., 1453 Adler; Sch. E., Ph. 109, p. 263, 15-17 Schwartz.

${ }^{66}$ Bury (1886: 160).

${ }^{67}$ Pi., N. 4, 35 Snell \& Maehler; Theoc. II, 17 y 69 Gow; A., Pers. 974, 988-989 Page.

${ }^{68}$ Thompson (1895: 73); Cook (1914: 253, n. 3).

${ }^{69}$ Chantraine, s.v. íw e 'Í́ (1968-1980: 475); Beekes, s.v. íw (2009-2010: 608).

${ }^{70} \mathrm{Pi}$., fr. 128a, 8 Snell \& Maehler.

${ }^{71}$ Hsch., 11111 [texto cit. n. 110]; Sch. Ar., Lys. 1110, p. 41, 21-22 Stein; Sud., 1761 Adler; Syn. Lex. 1 152, p. 279 Cunningham = Lex. Seg. 1, p. 264, 26 Bachmann; Et. Gud. 1, col. 285, 12 Sturz; EM, p. 479, 56-57 Gaisford. Cf. Eust. Macrembol., Hysmine et Hysminias I, 14, 5, p. 11, 8 Marcovich. 
se asocia explícitamente a la rueda e implícitamente a las fórmulas de encantamiento que, según se cree, habrían de pronunciarse durante la celebración de un ritual mágico:

La señora de los dardos más punzantes, la nacida en Chipre, habiendo atado un

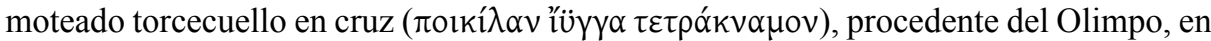

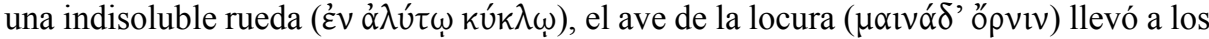

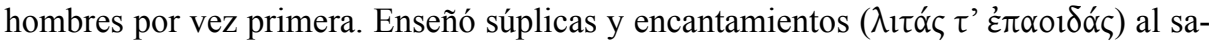
gaz hijo de Esón, para que arrebatara ( $\left.\alpha \varphi \varepsilon^{\prime} \lambda o \imath \tau^{\prime}\right)$ a Medea la honra debida a sus padres, y el anhelo de la Hélade la sacudiera, a ella que ardía ( $\kappa \propto 10 \mu \varepsilon ́ v \alpha v)$ en sus entrañas, con

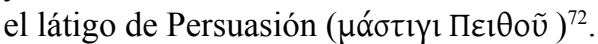

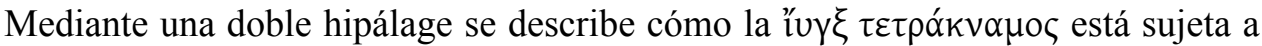

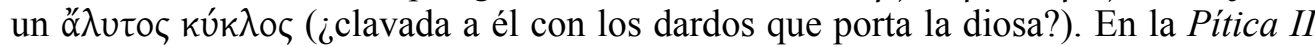

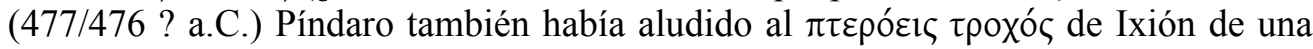

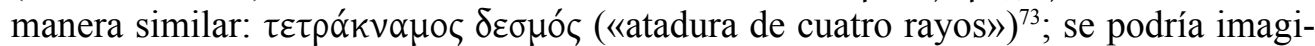
nar que una rueda con un torcecuello atado a ella es una «rueda alada». Los escolios

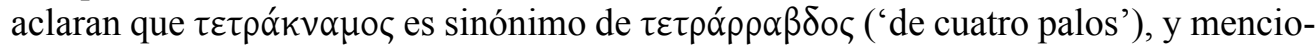

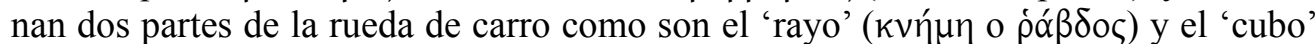
$(\chi 0 ı v ı k i ́ \varsigma)^{74}$. El torcecuello, así pues, supuestamente vivo, habría de quedar fijado a la rueda de modo aproximado a como, según documenta la iconografía, estuvo Ixión atado a la suya: «cross-fixed or spread-eagled $\rangle^{75}$. Otra observación: en Píndaro se ates-

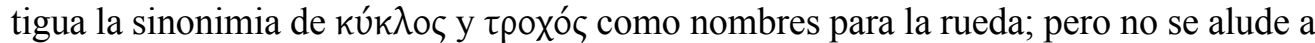
que éstos hubieran de girar.

Los críticos han justificado con razones diversas por qué se ataba el torcecuello a la rueda en la ceremonia mágica. Según la interpretación de Simpson, aplaudida por

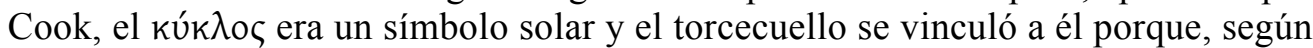
la creencia popular, el pájaro buscaba con la mirada el astro rey cada vez que volvía la cabeza hacia atrás (también sería solar la rueda de Ixión) ${ }^{76}$; sin embargo, en los textos antiguos sobre el torcecuello no hay indicio que dé pie a una explicación tal ${ }^{77}$. Para Robinson la ı̌uץ $\xi$ de Píndaro podría tener un origen iranio y representa el motivo de la rueda de la Fortuna ${ }^{78}$. Gow, a su vez, sospechó que el torcecuello pudo usarse en la magia amorosa por su manera peculiar de mover el cuello cuando realiza el cortejo

${ }^{72}$ Pi., P. 4, 213-219 Snell \& Maehler. Cf. A. R. III, 758-760 Vian \& Delage.

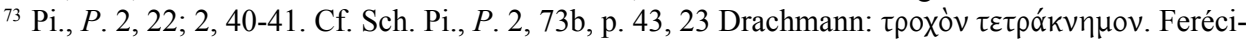

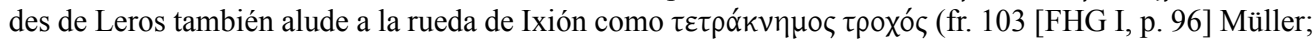

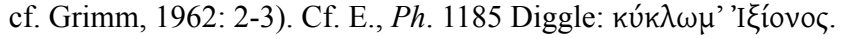

${ }^{74}$ Sch. Pi., P. 2, 73a, p. 43, 14; 2, 73b, p. 43, 18-19 Drachmann.

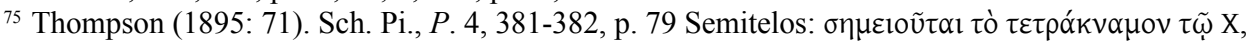
o sea, se trata de una crux decussata de ángulos oblicuos — dos agudos, dos obtusos_ y no de una cruz griega de ángulos rectos. Ruiz de Elvira (1992-1993) señala que ya en la Antigüedad se solió confundir aquella cruz con esta otra. Cf. Sch. Pi., P. 2, 73b, p. 43, 22-24 Drachmann.

76 Simpson (1896: 164); Cook (1914: 253-254). Cf. Nelson (1940: 446).

${ }^{77}$ La conjetura podría partir de Anaximand. 126 Kirk \& Raven =Vorsokr. 12 [2], A 21, p. 87, 10-13 Diels \& Kranz (Aët., Placit. II, 20, 1 Diels; Aëtiana, p. 512, 516, 519, 529 Mansfeld \& Runia).

78 Robinson (1946: 210-212). 
de apareamiento ${ }^{79}$, o, añadirá Böhr, cuando se muestra amenazante al sentirse amenazado ${ }^{80}$. Thompson sugiere que en la práctica opera «a phallic symbolism» ${ }^{81}$ derivado — se sobreentiende - de la forma del pescuezo del ave al estirarse y doblarse: la conjetura parece inspirada en el fabuloso phallos-bird de los vasos áticos ${ }^{82}$ (el falo fue en ocasiones un símbolo apotropaico ${ }^{83}$; en cambio, la naturaleza de la ${ }^{\prime} v \gamma \xi$ es siempre unitiva y nunca apotropaica). Mayor divulgación goza el planteamiento de Tavenner: el torcecuello se asemeja a la rueda giratoria por su modo de torcer el cuello cuando se lo aprisiona en mano, de modo que fue atado a ella por analogía del movimiento ${ }^{84}$; sin embargo, habiendo observado un torcecuello, yo no diría que su cuello traza círculos (como sí hacen los alcedínidos). Segal opina que los movimientos sinuosos de su cuello y cola debieron de sugerir a los griegos «sensuality and debauchery» ${ }^{85}$. A partir de una tradición oral bereber, Bynon conjetura que la creencia en su poder mágico para amarrar a una persona proviene de su habilidad para atrapar gran número de hormigas con su pegajosa y rapidísima lengua ${ }^{86}$, como si las capturara «by some magnetic influence» ${ }^{87}$. Faraone, en cambio, refutando a Gow, opina que Jasón se sirvió del torcecuello como representación de Medea, cual muñeco de vudú, con el fin de

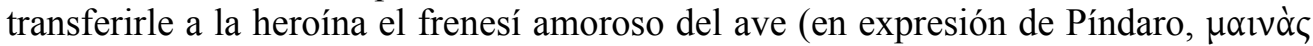
ópviৎ) y hacerla delirar de amor ${ }^{88}$; según Faraone, además, la rueda se habría usado como un instrumento de tortura similar a la cruz decusata y no, como suele creerse, haciéndola girar: sólo así cobran pleno sentido las alusiones de Píndaro a que la víctima era flagela $\left(\mu \alpha \alpha_{\sigma \tau \imath}\right)$ y quemada ( $\left.\kappa \alpha 10 \mu \varepsilon ́ v \alpha\right)$, así como la indicación de un escolio según la cual el torcecuello debía ser destripado ${ }^{89}$; Faraone suscita la imagen macabra de un pájaro crucificado.

Sea como fuere, en fechas tempranas el referente de $\imath^{\prime} v \gamma \xi$ ya había dejado de ser necesariamente el torcecuello, según consta en la poesía, sobre todo en el drama. En Persas de Esquilo (472 a.C.) " ${ }^{\prime} \gamma \xi \xi$ comporta el significado de, según los escolios, $\varphi \imath \lambda i ́ \alpha$,

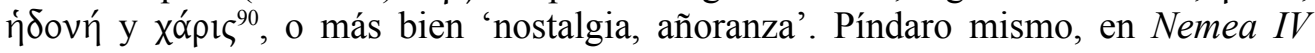

\footnotetext{
${ }^{79}$ Gow (1934: 3), seguido por Detienne (1994: 84). Cf. Silva (2008: 146-148).

${ }^{80}$ Böhr (1997: 116-118).

${ }^{81}$ Thompson (1895: 71).

${ }^{82}$ Lamberton \& Rotroff (1985: 23, fig. 43).

${ }^{83}$ Funari (1995: 9-10). Cf. Moser (2006).

${ }^{84}$ Tavenner (1933: 117). Cf. Pirenne-Delforge (1993: 284).

${ }^{85}$ Segal (1973: 33). D. P., Au. 1, 23 [texto cit. n. 18].

${ }^{86}$ Bynon (1987: 157). Cyran. I, 10, 35-36 Kaimakes [texto cit. p. 234].

${ }^{87}$ Dixon (1888: 131).
}

${ }^{88}$ Faraone (1993; 1999: 57-69). Friedrich (1997: 309-310) observa que los pájaros, por sus rasgos físicos y fisiológicos, así como por sus conductas sociales y parecer que hablan lenguas, son animales que se asimilan fácilmente al hombre. Cf. Gilhus (2006: 26-28, 54-56, 201, 248-250).

${ }^{89}$ Sch. Pi., P. 4, 381a, p. 149, 18-19 Drachmann (cf. Sch. Lyc., Alex. 310, p. 126, 16-17 Scheer): ó $\tau$

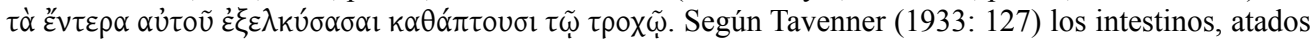
alrededor de la rueda cual cintas, incrementaban la eficacia del movimiento circular. En la Tragicomedia de Lisandro y Roselia (Salamanca, 1542) Sancho de Muñón enumera las «entrañuelas de torcecuello» (ed. R. Navarro Durán, Madrid, 2009: 168) entre los ingredientes empleados por las hechiceras.

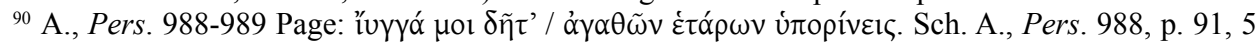
Dindorf y 991, p. 259 Dähnhardt. 
(473 ? a.C.), parece darle el sentido de 'hechizo (de amor) ${ }^{91}$. En Enómao de Sófocles (post 414 a.C.) ไ̌vy expresa la 'atracción' que irradia la mirada de Pélope y que tiene a Hipodamia embobada ${ }^{92}$; en Lisistrata de Aristófanes (411 a.C.), el 'sex-appeal' de la

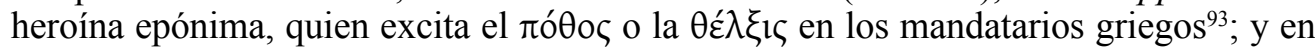
Alejandra de Licofrón (s. III ? a.C.), el ह̌ $\rho \omega \varsigma$ o 'deseo' incendiario que el bello físico del joven Troilo despierta en el héroe Aquiles ${ }^{94}$. En el Onomastikon, diccionario de ideas del siglo II d.C., Pólux de Náucratis viene a confirmar las noticias ulteriores de los escoliastas al alistar 'íy\} junto a otras voces que significan 'deseo amoroso, sexual':

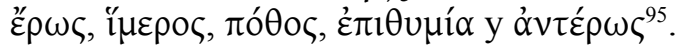

Gran atención de la crítica ha recibido el idilio La hechicera (ca. 264-260 a.C.) de Teócrito. Su célebre estribillo, que se repite durante la realización de un ritual de

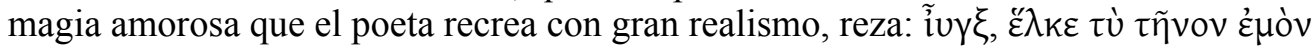

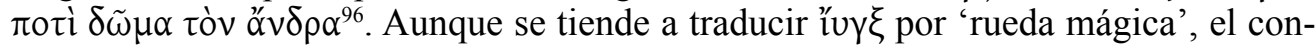
texto literario en verdad no evidencia que sea éste el sentido exacto. En mi opinión la

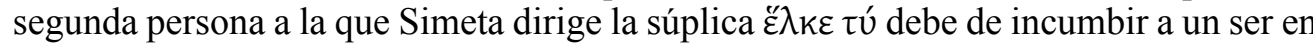
verdad animado más que a uno inanimado cual es la rueda (si bien habrá quien opine que está personificada): «itorcecuello, arrastra tú a mi hombre aquel hasta la casa!». El escolio relativo aclara:

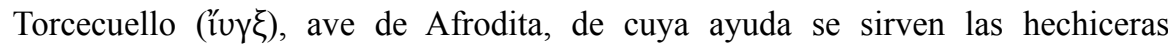
( $\varphi \alpha \rho \mu \alpha \kappa i ́ \delta \varepsilon \zeta)$ en sus prácticas mágicas ( $\mu \alpha \gamma \varepsilon i ́ \alpha l)$. Pues, después de ponerlo sobre una

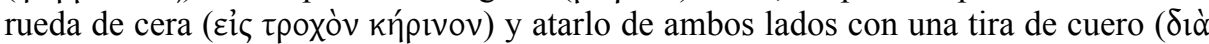

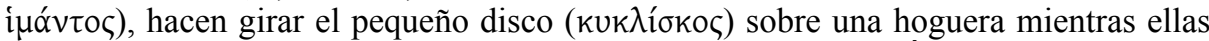
dan vueltas y recitan el encantamiento ( derrite suavemente. Y al mismo tiempo se añade a ello si viene al caso: «como se derrite

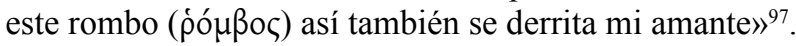

Está claro que para el escoliasta, quien además tiene presente el pasaje ya citado

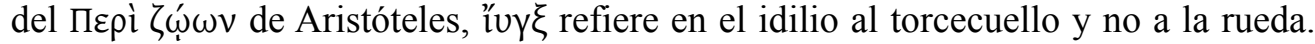

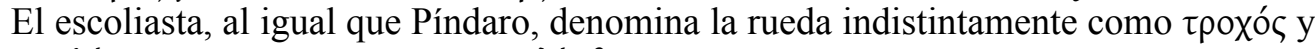

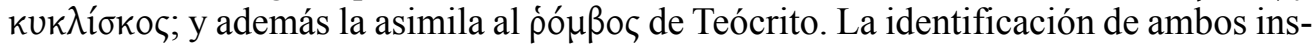
trumentos debió de verse favorecida por el hecho de que en La hechicera de Teócrito

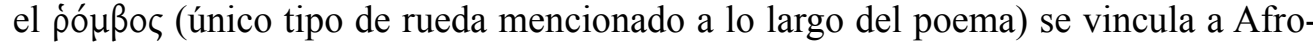

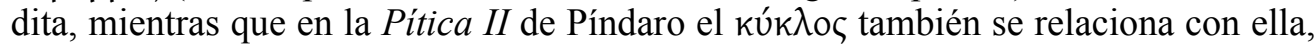
la diosa Ciprogenia. Llegados a este punto, el escoliasta pudo haber inferido que el

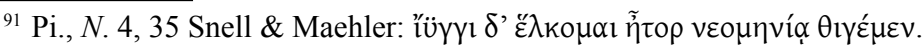

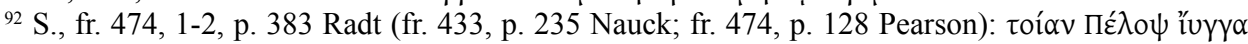

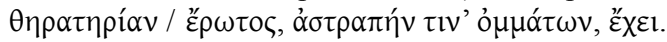

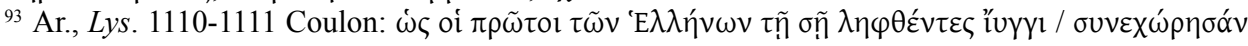
бol. Sch. Ar., Lys. 1110, p. 41, 21-22 Stein; Sud., i 761, 3-6. Faraone (2006: 217-219).

${ }^{94}$ Lyc., Alex. 309-310 Mascialino: ös $\tau$ ' ớp

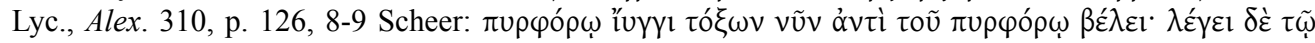
है $\rho \omega \tau$. Sobre la Alejandra véase Clúa Serena (2003).

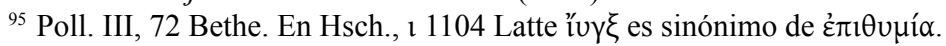

${ }^{96}$ Theoc. II, 17-ss. Gow. Fernández Fernández (2002) compara el ritual de Teócrito con los PMag.

${ }^{97}$ Sch. Theoc. II, 17, p. 274, 6-12 Wendel. Cf. Sch. Lyc., Alex. 310, p. 126, 13-16 Scheer. 


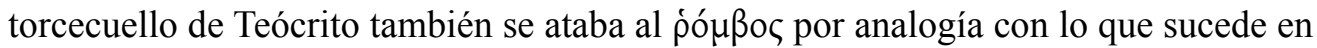
el mito de Píndaro, donde el torcecuello sería un instrumento de la diosa. Sin embargo,

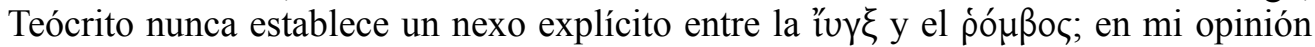
esta relación tampoco se desprende de la lectura del poema. La invocación de la îuү $\xi$, que funciona como fórmula mágica repetitiva, no es exclusiva de una acción particular, la de dar vueltas al ṕó $\beta$ os, sino se realiza en cada una de las nueve acciones que conforman el ritual, confiriéndole cohesión (también desde el punto de vista formal de la estructura literaria) e incrementando su eficacia mágica.

Aunque Teócrito se refiere a un «rombo de bronce» ( $\rho$ ó $\mu \beta \circ \varsigma$ ó xó $\lambda \kappa \varepsilon \circ \varsigma$ ), el esco-

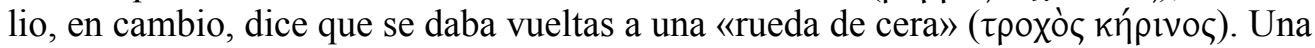
vez más el escoliasta debió de recordar alguna noticia independiente de Teócrito (en rituales de magia amorosa, verbigracia, los Papiros griegos de magia documentan el uso de figuras antropomórficas o zoomórficas fabricadas de materias maleables

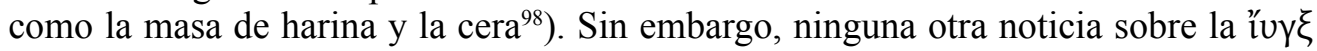
menciona una rueda tal. El escoliasta debió de creer - «a foolish inference ${ }^{99}-$ que la rueda era de cera al confundir o mezclar, según parafrasea el texto, dos estrofas de $L a$ hechicera donde la cera remite por sinécdoque a una figura que representa a la persona deseada $^{100}$ :

Como yo derrito esta (figura de) cera con el favor de un demon, así al instante se derrita de amor Delfis de Mindo.

Como rueda este rombo broncíneo proveniente de Afrodita, así ruede él hasta mi puerta ${ }^{101}$.

En las Cyranides (s. I-III d.C.), mucho antes de escribirse dicho escolio, también se asumió que la ${ }^{\prime \prime} u \gamma \xi$ de Teócrito es un ave y no la mentada rueda. Al explicar que el pájaro torcecuello, aquí llamado kıvoí́1os, participa junto con otros seres homónimos de los reinos vegetal, mineral y animal (a saber: verbena, obsidiana y blénido) de una cadena de simpatía de naturaleza afrodisíaca, se saca a colación el famoso verso $\tilde{\imath} u \gamma \xi$, $\varepsilon \check{\iota} \lambda \kappa \varepsilon \tau u ́(\kappa \tau \lambda)$ para conferir auctoritas a lo dicho ${ }^{102}$. Las Cyranides, además, atribuyen al torcecuello otras propiedades mágicas y medicinales:

Si uno lleva la lengua $(\gamma \lambda \tilde{\omega} \sigma \sigma \alpha)$ del ave en una lámina de oro, tendrá encanto ( $\chi \alpha ́ p ı \varsigma)$ y será querido por todos, dioses y hombres. Su rabadilla (ỏ $\beta$ orúyıv) dada ocultamente a un hombre o a otro animal macho: éste se afeminará y realizará acciones propias de las hembras. Si uno lleva el ojo (ỏ $\varphi \propto \alpha \lambda \mu$ ó $)$ derecho del ave bajo un lapislázuli

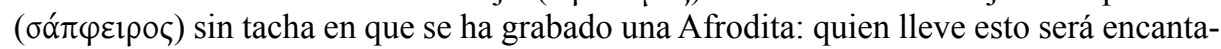

${ }^{98}$ PMag. IV, 296-302, 1872-1878, 2359-2363, 2944-2945, 3131-3132; XIII, 309 Preisendanz \&

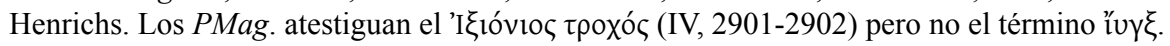

${ }^{99}$ Gow (1936: 8).

${ }^{100}$ Cf. Verg., Buc. 8, 74-75 Coleman: Terque haec altaria circum / effigiem duco.

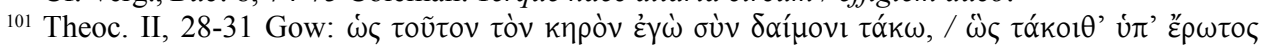

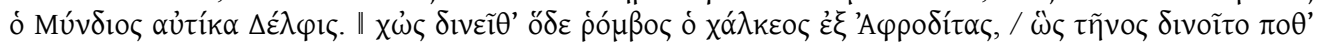

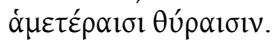

${ }^{102}$ Cyran. I, 10, 4-9 Kaimakes. 


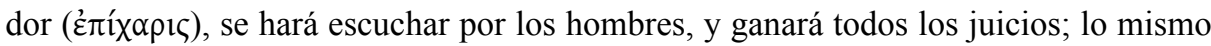
realiza también el ojo izquierdo de llevarlo una mujer. Su sangre ( $\alpha \tilde{i} \mu \alpha)$ mezclada con cualquier colirio y aplicada como linimento evacua la sufusión ocular ${ }^{103}$. Su corazón ( $\kappa \propto \rho \delta i ́ \alpha)$, atado como amuleto al ponerse la Luna, cura fiebres tercianas y cuartanas.

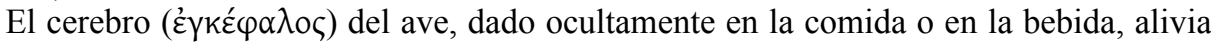
la cefalea incurable. Su hígado ( $\tilde{\eta} \pi \alpha \rho)$, macerado en salmuera, quita las enfermedades hepáticas ${ }^{104}$.

En su paráfrasis latina de La hechicera de Teócrito, esto es, en la Bucólica VIII (39 a.C.), Virgilio tradujo "uy $\xi$ por carmina o 'encantamientos', mientras que Servio (s. IV d.C.), comentando a su vez el texto de Virgilio, explicó carmina como turbo: con ello insinúa en el lector, cual especie de silogismo, que la $\iota^{\prime} \gamma \xi \xi$ del idilio griego - cuyo célebre estribillo Servio por supuesto conoce y también cita- era una turbo o 'aparato giratorio' ${ }^{105}$. Los textos citados ilustran la siguiente conjetura de Faraone: a partir del período helenístico tardío probablemente empezaron a confundirse distintos instrumentos que tal vez sólo tenían en común el hecho de que se venían usando, cada uno a su manera, en prácticas de magia amorosa, entre ellos la $\iota^{\prime} v \xi$, la turbo y el rhombus $^{106}$. Gow atribuyó esta confusión, que aún perduraría en nuestros días ${ }^{107}$, a los comentaristas de Virgilio que consultaron los comentarios de la obra de Teócrito ${ }^{108}$. Según el comentarista de Horacio conocido como Pseudo Acro (s. VI-VII), los tres términos referidos denominan un mismo tipo de maleficium amoroso ${ }^{109}$; el hechizo debió de conocerse, por sinécdoque, con el nombre del aparato usado para causarlo.

La entrada "̌y ${ }^{\prime}$ del Léxico de Hesiquio (s. v-VI) apunta la evolución semántica del término: primero habría designado el torcecuello; después adquiere por metonimia el

${ }^{103}$ Dado que todos los usos descritos son beneficiosos o curativos, no parece acertado el significado

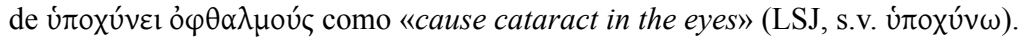

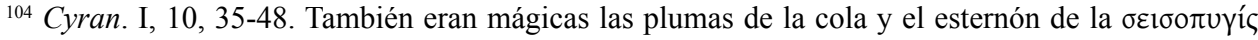
(Sch. Opp., H. IV, 132, p. 348, 9-10 Bussemaker).

${ }^{105}$ Verg., Buc. 8, 68-ss. Coleman: Ducite ab urbe domum, mea carmina, ducite Daphnin. Seru., Buc. 8, 21, p. 95, 11-12 Thilo: O turbo maritum meum adducitum. Bury (1886: 158-159); Thompson (1895: 72); Tavenner (1933: 111-112). Cf. Sch. Theoc. II, 17, p. 274, 6-12 Wendel [texto cit. supra]. Sannazaro, Herpylis pharmaceutria 32: Volvite praecipitem jam nunc, mea licia, rhombum; 34: Volvite praecipitem, mea licia, volvite rhombum; Quevedo, Farmaceutria 111-112: «Quiero traer el rombo a la redonda: / varios lazos en él tengo tejidos» (citas en Pérez-Abadín Barro, 2005: 112).

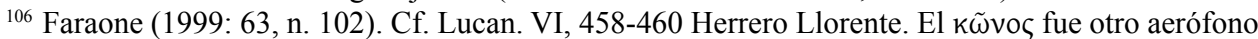
rotatorio que se usó en ritos mistéricos (Clem. Al., Protr. II, 17, 2 Stählin = Eus., PE II, 3, 23 Mras; Sch. Clem. Al., Protr. 14, 12, p. 302, 27-33 Stählin \& Treu).

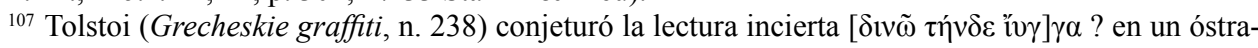
con del s. V a.C. procedente de Kerch. Lebenev (1996: 273) lo describe así: «In a magical ostrakon from Pantikapaion, the portrait of a male victim is placed on the recto, the love spell on the verso. Incidentally, on the verso it has a hexagonal desing interpreted by Tolstoi as magical rhombos or iynx rotated by the

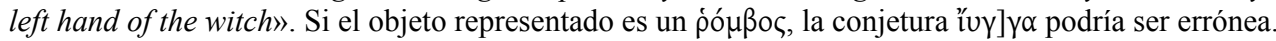

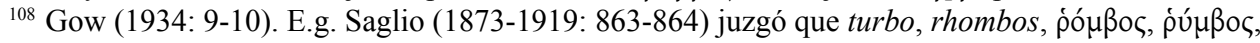

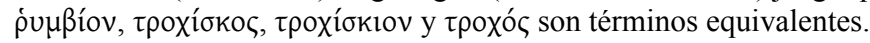

${ }^{109}$ Ps. Acro, In Hor. Epod. 17, 7, p. 451, 20-24 Keller: Turbo species est maleficii, cuius uertigini

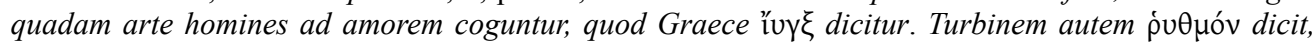
quem Graeci dicunt rhombum. 
significado de $\varphi$ í $\tau \rho \rho v$ (pudiera ser la acepción más común en época del autor); y finalmente amplía su extensión para nombrar todo remedio o preparativo que se concibe

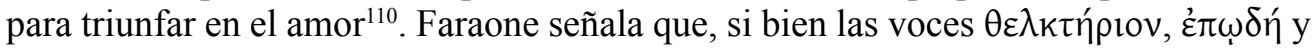
$\varphi \alpha ́ \rho \mu \alpha$ Kov ('charm, magical incantation') pueden significar en ciertos contextos 'love

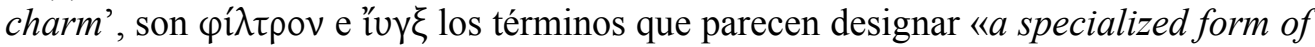
erotic spell ${ }^{111}$. En los Memorables (ca. 371-392 a.C.) de Jenofonte Sócrates aconseja a la hetera Teódota que, para ganar clientes y después conservarlos, recurra a $\varphi$ í $\lambda \tau \rho \alpha$,

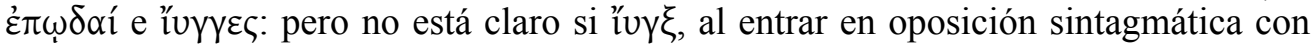
las otras dos voces, alude a un encantamiento, a la rueda mágica o al pájaro ${ }^{112}$. Los

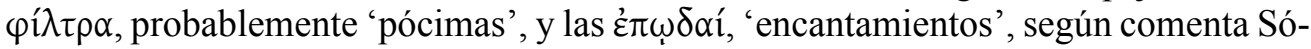

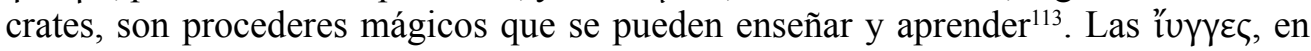
cambio, ausentes del comentario, habrían de ser el instrumento o el ave: ese mismo

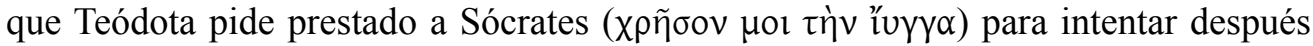
seducirlo a él, ¡al más sabio de los hombres! Llama la atención que Hesiquio no recoge el significado de "ư $\xi$ como 'rueda'. La sugestiva conjetura de Capponi según la cual "uү $\xi$ designó en su origen un "congegno primitivo di aucupio" a forma di ruota»" ${ }^{114}$ también pierde fuerza ante otro hecho: en Sobre la captura de aves, de un tal Dioniso, íuץ $\xi$ designa un pájaro y no a una técnica de apresamiento, señuelo o trampa ${ }^{115}$.

En un poema de la Antología palatina ${ }^{116}$ la voz "uy $\xi$ connota el matiz propiamente

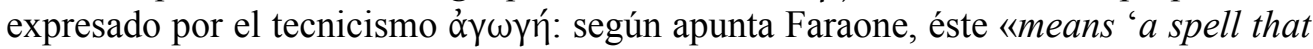
leads' and designates a variety of techniques used to force young women from their homes» ${ }^{117}$. En las fuentes literarias la acción que comúnmente realiza la "uy $\xi$ como

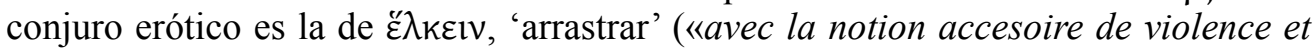
mauvais traitements ${ }^{118}$ ) a una persona hacia un deseo o amor exaltados ${ }^{119}$, doblegan-

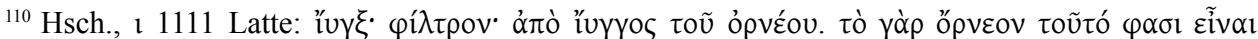

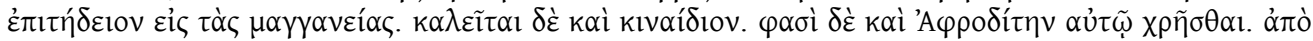

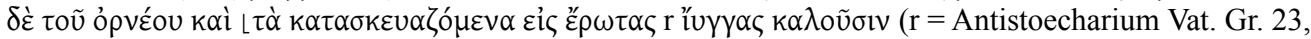
S. XIV).

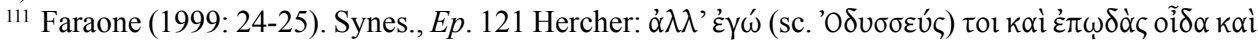

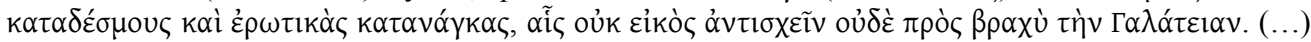

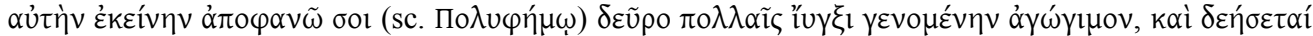

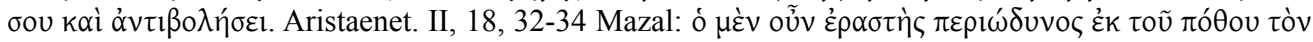

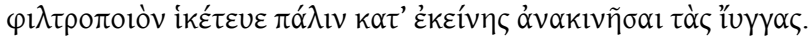

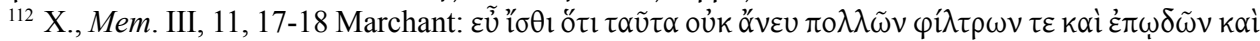

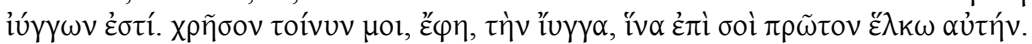

${ }^{113}$ X., Mem. III, 11, 16. Cf. Souto Delibes (2000: 496-500), donde comenta el capítulo 11.

${ }^{114}$ Capponi (1981: 298).

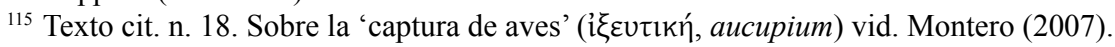

${ }^{116}$ Hellen. Epigr. I, Anon. 35 [texto cit. n. 206]. Segal (1973: 40-41).

${ }^{117}$ Faraone (1999: 25). Cf. PMag. IV, 1390, 1496, 2539, 2887 Preisendanz \& Henrichs.

${ }^{118}$ Chantraine, s.v. हैं $\kappa \omega$ (1968-1980: 339-340).

${ }_{119}$ Pi., N. 4, 35; X., Mem. III, 11, 17-18 [texto cit. n. 112]; Theoc. II, 17; Luc., Dom. 13, 6 [n. 180]; Ael., NA V, 40, p. 128, 23-24 [n. 128]; Hsch., 1 1104; AP V, 205 [n. 206]; Phot., Lex. I, p. 118, 19-20

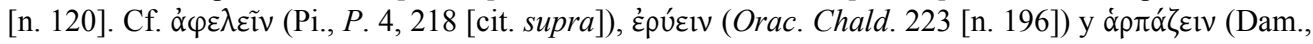

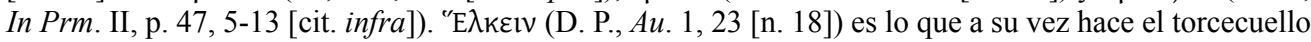
con la lengua para embucharse las hormigas. 
do si es menester la resistencia de la 'razón' $(\delta i o ̛ ́ v o l \alpha)^{120}$. De manera afín, la acción de seducir, en su sentido etimológico (se-ducere), radica en conducir a la persona deseada hasta un lugar apartado. Douglas advierte la ambigüedad del texto en cuanto a si los

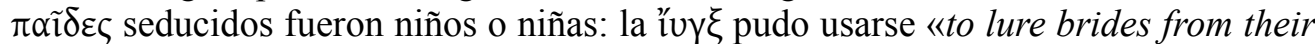
nuptial chambers, or little children out of the women's apparments» ${ }^{121}$.

En otros contextos literarios, sin embargo, la connotación semántica de atracción erótica aparece neutralizada: por ejemplo, Filóstrato menciona unas ǐuүyeৎ o especie de 'ensalmos' que, según se espera, han de devolver la vida a quien la acaba de perder

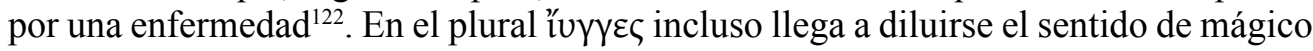
inherente a toda fórmula de encantamiento, de modo que la voz connota, en relación a un discurso, su capacidad para persuadir $(\pi \varepsilon 1 \theta \omega ́)$ a oyentes o lectores, quienes, más que convencidos por los argumentos esgrimidos, se embelesan con la sonoridad de las palabras conforme fluyen: así, era un placer escuchar a Diógenes de Sínope, orador carismático y con grandes dotes para la persuasión ${ }^{123}$; las multitudes acudían al desierto a escuchar fascinadas los sermones de Jesucristo ${ }^{124}$; las cartas de Herculiano deleitaban y sosegaban a Sinesio de Cirene ${ }^{125}$; y Pselo alaba la belleza encantadora de las odas

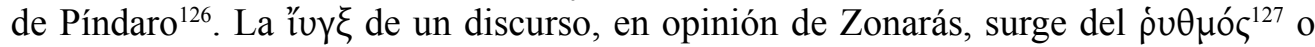
'tempo narrativo'. En contextos donde aparece la voz '̌uj $\xi$ el término $\pi \varepsilon l \theta \omega ́$ adquiere a su vez el matiz de 'seducción erótica' o 'persuasión retórica'.

No obstante, la $\iota^{\prime} u y \xi$ no es una cualidad exclusiva de la palabra, sea mágica o no. Asimismo tienen $\iota^{\prime} u y \xi$ los adornos que suelen usar las mujeres para resaltar su belleza y potenciar su atractivo físico: perfumes, joyas de oro, piedras preciosas ${ }^{128}$; seguramente Cleopatra los usó para conquistar primero a Julio César y después a Marco Antonio $^{129}$. En ornamentos personales incluso se pudo representar el torcecuello como motivo figurativo: para Tufnell es un torcecuello, que no un halcón, el ave que figura

${ }^{120}$ Phot., Lex. I, p. 118, 19-20 Porson (Sud., i 761, 1 Adler; Zonar., Lex., col. 1132, 18-20 Tittmann;

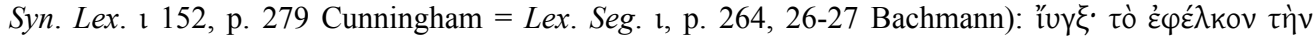

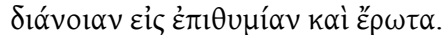

${ }^{121}$ Douglas (1927: 93).

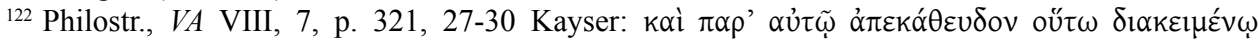

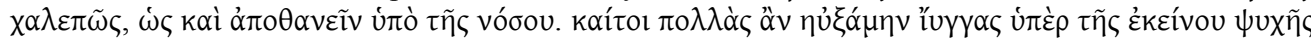

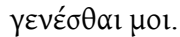

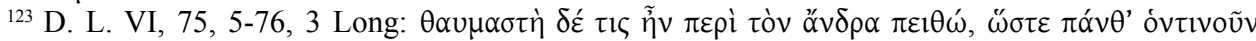

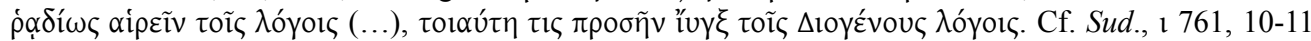
Adler; Zonar., Lex., col. 1132, 15-17 Tittmann.

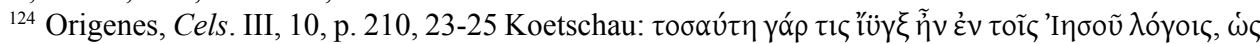

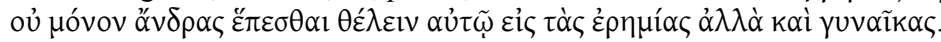

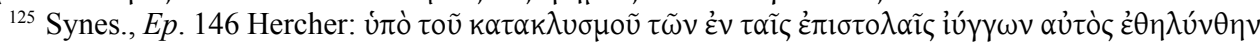

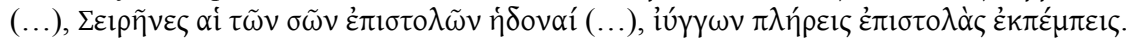

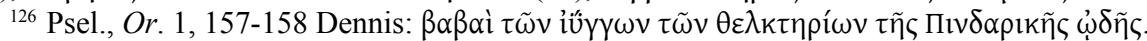

${ }^{127}$ Zonar., Lex., col. 1132, 15 Tittmann. Cf. Ps. Acro, In. Hor. Epod. 17, 7 [texto cit. n. 109].

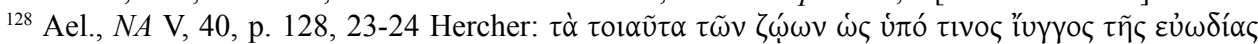

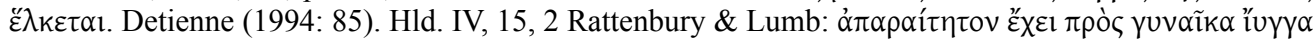

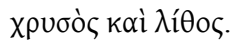

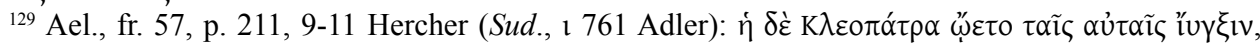

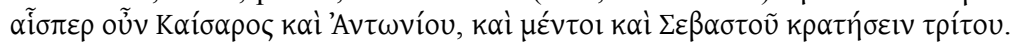


tanto en los pendientes de Tutankhamon como en varios aretes de oro hallados en Tell el-’Ajjul, Gaza ${ }^{130}$. También tiene '̌́ o el flautista de Hamelín, ejerce una atracción irresistible sobre los animales ${ }^{131}$. Y tiene ı̌ una persona encantadora ${ }^{132}$, como lo es el santo que cultiva la virtud ${ }^{133}$.

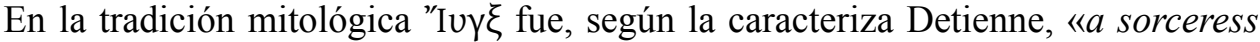
who is an expert on love philtres» ${ }^{134}$. Así pues, pudiera ser ella, en lugar del torcecuello o la rueda mágica, la persona a la que invoca Simeta en La hechicera de Teócrito ${ }^{135}$. Dos son los mitos referentes a Iunx. El primero fue extraído por Antonino Liberal (s. II d.C.) de los Heteroioumena de Nicandro (s. II a.C.): según relata, las Piérides, quienes presumían de ser talentosas cantantes, retaron a las Musas en un certamen musical que acabaron perdiendo ${ }^{136}$; las Musas, para castigar su jactancia, transformaron a las Piérides en nueve aves, contándose entre ellas Iunx: degradada y transformada en torcecuello, debió de perder el don del canto melodioso que la leyenda le presupone ${ }^{137}$.

En el escolio de La hechicera ya citado se atribuye a Calímaco, el sucesor de Zenódoto al frente de la Biblioteca de Alejandría, otro mito: Iunx, ahora hija de Eco, fue metamorfoseada en pájaro por Hera como castigo por haber pretendido seducir a Zeus mediante la magia ${ }^{138}$. Según la variante recogida por Focio, Hera petrificó a Iunx, hija de Eco o Persuasión, por haberle dado a Zeus una pócima para que hiciera el amor con Ílo ${ }^{139}$ : Iunx habría heredado de Eco su voz «lancinante et répétitive» mientras que de Persuasión su carácter «persuasive et même fourbe» ${ }^{140}$; en ambos casos subyace la creencia de que Iunx nació de una personificación del sonido ${ }^{141}$. Juan Tzetzes (s. XII), sabedor de la tradición literaria que vincula a Eco y $\mathrm{Pan}^{142}$, añade el detalle de que fue éste el padre de Iunx, y confirma que Hera convirtió a Iunx en el ave homónima

${ }^{130}$ Tufnell (1983: 58, fig. 1, lám. XXI y XXII).

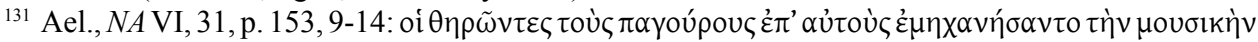

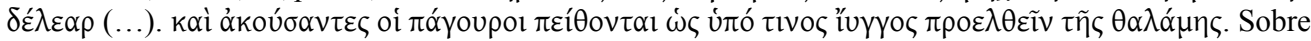
Orfeo vid. Molina Moreno (2003: 181-195); sobre Anfión, Paus. IX, 5, 7-9 Rocha-Pereira.

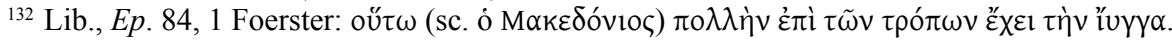

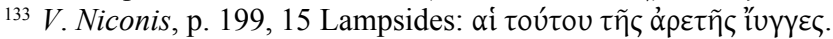

${ }^{134}$ Detienne (1994: 83).

${ }^{135}$ En Theoc. II, 15-16 Gow también se menciona a las hechiceras Circe, Medea y Perimede.

${ }^{136}$ Rodríguez López \& Pérez Suescun (1997: 56) aluden a una anécdota similar sobre las Sirenas.

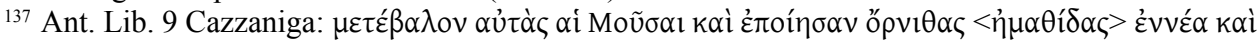

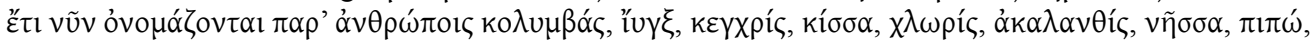
$\delta \rho \alpha k o v \tau i ́ c$. La paloma, el torcecuello, el halcón, la picaza, la oropéndola y el pato, a diferencia del jilguero y la alondra, no sobresalen por ser aves canoras.

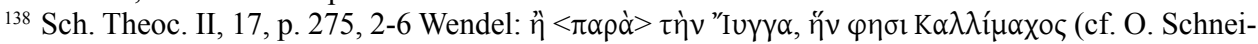

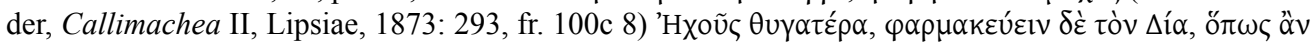

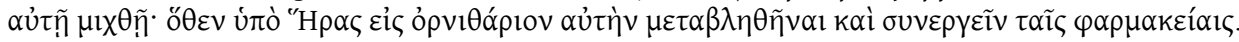

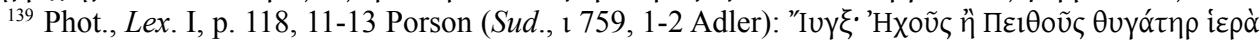

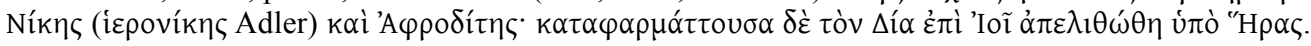
Cf. Sud., $1761,7-8$; Sch. Ar., Lys. 1110, p. 41, 22-23 Stein.

${ }^{140}$ Pirenne-Delforge (1993: 285).

${ }^{141}$ Johnston (1990: 95, n. 17).

${ }^{142}$ E.g. HHom. Pan. 21 Allen \& Sikes; Philostr., Im. II, 11, p. 357, 8-27 Kayser; Callistr. 1, 5, p. 46, 21-47, 3 Schenkl \& Reisch; Nonn., D. XLVIII, 489-495 Koechly; Sud., $\alpha 1241$ Adler. 
por haber propiciado el devaneo de Zeus con la sacerdotisa de $\operatorname{Argos}^{143}$ : de Pan, quien vivía una sexualidad salvaje y desacerbada, Iunx habría heredado la promiscuidad sexual y el rechazo a contraer matrimonio ${ }^{144}$. Estos relatos, elaborados en el período helenístico, se asemejan a mitos etiológicos que justifican el uso tradicional del torcecuello en la magia amorosa.

Focio también recoge el testimonio de Zenódoto de Éfeso (s. IV-III a.C.) según el cual hubo quien identificó a Iunx con Menta ${ }^{145}$. Detienne justifica la equiparación en clave sociológica: una y otra, por oposición a la figura de la esposa, son arquetipos de «la querida». Menta, que fue tomada por Hades como concubina, rivaliza con su esposa Perséfone en el mundo inferior, mientras que Iunx, en el mundo superior, es la mujer fatal o celestina que se entromete en la relación de Zeus y Hera, paradigma mítico del matrimonio monógamo. Ante este patrón, Detienne propone que Ixión fue castigado por Zeus y encadenado a una rueda por intentar enamorar a Hera ${ }^{146}$. En coherencia con la interpretación del belga, Segal subraya que la voz "ú recer en contextos de amor repentino, violento, embaucador, efímero, inconstante o ilegítimo, y por ende infeliz ${ }^{147}$. El papel mediador de Iunx en infidelidades amorosas pudo contribuir a que el torcecuello recibiera el nombre peyorativo de kıvaí $\delta 10 \varsigma$, en alusión al 'prostituto' ( $k i ́ v \propto 1 \delta \circ \varsigma$ ) afeminado que incita conductas sexuales indecentes y reprobables. Traición e infortunio encubría asimismo el canto de las Sirenas: «porque atraen con la dulzura de su voz a quien se fía de ellas y, luego, lo aniquilan (...): lo que se adivina detrás de las Sirenas es el ansia de placeres, que van aniquilando poco a poco a quienes se han rendido y se han visto embrujados por sus deleites» ${ }^{148}$. Sinesio

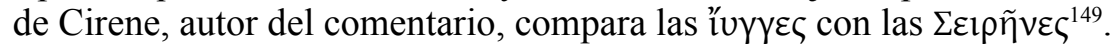

Tavenner puso de relieve que en la iconografía de la cerámica griega nunca se representa un torcecuello atado a la rueda, como describe la Pítica IV, sino tan sólo posado en la mano de un enamorado, sea mujer sea varón, o en la del dios $\operatorname{Eros}^{150}$. Se trata de torcecuellos que debieron de ser domesticados y que ya no muestran ademanes defensivos en presencia de personas ${ }^{151}$. Para Tavenner, con todo, el testimonio de los vasos en la cuestión del uso mágico del pájaro es «either irrelevant or unconvincing» ${ }^{152}$,

${ }^{143}$ Sch. Lyc., Alex. 310, p. 126, 19-22 Scheer. Cf. Sch. Pi., N. 4, 56a, p. 73, 15-16 Drachmann.

${ }^{144}$ Cf. Borgeaud (1988: 55-56, 79-86).

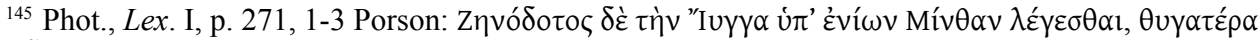

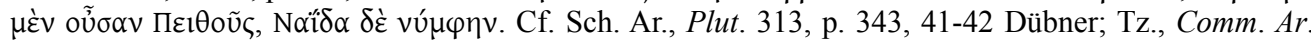
Plut. 313, 1-2 Massa Positano.

${ }^{146}$ Detienne (1994: 86-90); Pirenne-Delforge (1993: 286). Cf. Apollod., Epit. I, 20, p. 181, 1-7 Wagner.

${ }^{147}$ Segal (1973: 34-37, 41).

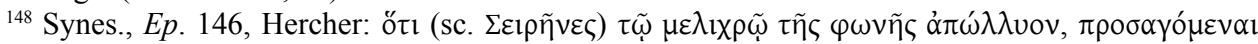

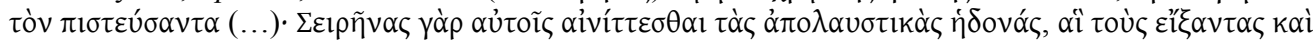

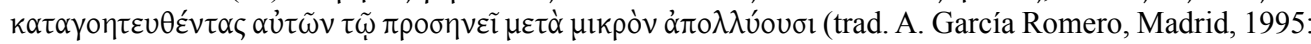
278). Cf. Heraclit., All. 70 Russel \& Konstan; Clem. Al., Prot. 12, 118, 1 Stählin.

${ }^{149}$ Synes., Ep. 146 [texto cit. n. 125]. Según Píndaro, fr. 94b, 13-15 Snell \& Maehler un coreuta podía

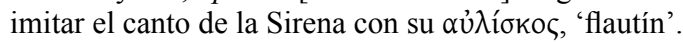

${ }^{150}$ Cf. Böhr (1997: fig. 1, 5, 7-8, 10-15).

${ }^{151}$ Böhr (1997: 116).

152 Tavenner (1933: 127). 
pues, según valora, las aves pintadas en las escenas, que incluso podrían no ser siempre torcecuellos, únicamente representan regalos de enamorados ${ }^{153}$. En cambio, las ruedas y los discos dibujados junto a los pájaros sí podrían simbolizar, según juzga Gow $^{154}$, atributos de Eros. En su trabajo sobre las representaciones de torcecuellos en los vasos áticos Böhr confirma que «no Greek vase-painting shows the bird seated on the magic wheel or fastened to it with widespread wings $\rangle^{155}$. Por tanto, los torcecuellos de las cerámicas deben de tener por sí mismos el poder mágico que se les presupone, con independencia del potencial mágico que a su vez puedan tener los instrumentos ilustrados con forma de rueda. Por analogía, el tipo iconográfico en que un torcecuello se posa libre en la mano de una joven podría explicar la relación entre Simeta y la "̌v $\gamma \xi$ en La hechicera de Teócrito: el ave sería un animal de compañía y mascota de buena suerte, acaso un regalo de su inconstante amante Delfis.

Cabe recordar dos imágenes del ave sin connotaciones eróticas. En una pintura mural de la Villa de Popea en Oplonte aparece con logrado realismo un torcecuello, posado sobre una tabla y picoteando tres peras ${ }^{156}$; la pieza plana de madera sugiere que se está alimentando en un entorno más bien doméstico. El mosaico de Ostia con número de inventario cat.DM6 muestra varias aves: la de la esquina inferior e izquierda, según Tammisto, podría ser un torcecuello (si es que no es una perdiz de Chukar) ${ }^{157}$.

Nelson dio a conocer la que, según parece, es la única representación antigua que se conserva de una rueda con el torcecuello: se trata de la llamada «the Iynx-wheel in Boston $\rangle^{158}$, una terracota procedente de Falerón, con $6,5 \mathrm{~cm}$ de altura y un diámetro de 21,5. Está formada por un aro con cuatro rayos y diseñada en horizontal para ser vista también desde abajo; motivos geométricos de estilo ático de la segunda mitad del siglo vIII a.C. decoran toda la cara inferior, rayos inclusive (entre ellos hay dos grupos de «ojos» con forma de hoja, un motivo al parecer apotropaico); en el lado superior se asientan en círculo las figuras de once aves que parecen torcecuellos, emitiendo tal vez un reclamo. Nelson conjetura que en medio de ellos, en la cruceta hoy descascarada, hubo un duodécimo torcecuello que se habría desprendido. En el aro se horadaron equidistantes cuatro orificios: la rueda debió de colgar de igual número de cordones.

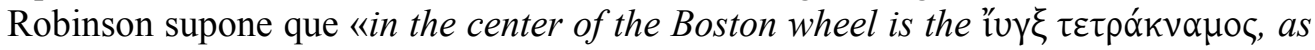
Pindar calls $i t\rangle{ }^{159}$. Con todo, no hay evidencia alguna de que esta rueda, que tiene valor estético y podría ser tan sólo un objeto decorativo, se haya usado como instrumento mágico; tampoco parece que pueda producir sonidos. Ahora bien, ¿será la rueda de Boston un antecedente remoto de ciertas ruedas dibujadas, por ejemplo, en los vasos de Apulia? Sería el caso de aquél donde Zeus pide ayuda a Afrodita para seducir a

\footnotetext{
153 Tavenner (1933: 119-125, 127).

154 Gow (1934: 3-5).

155 Böhr (1997: 118).

156 Watson (2002: 382-383, fig. 318).

157 Tammisto (1997: 73, 77, 83, 96, 142, 160, 188, 447, 462, lám. 34, fig. DM6,1).

${ }_{158}$ Museum of Fine Arts de Boston, inv. 28.49. Nelson (1940: fig. 1 y 3).

159 Robinson (1946: 211). Cf. Böhr (1997: 118-120).
} 
Leda $^{160}$ : de la mano de la diosa del amor, en cuyo antebrazo se sienta un Eros, cuelga horizontal una rueda de seis radios y dentada; me pregunto si sus dieciséis dientes podrían ser trazos simplificados de cuellos con cabezas de torcecuello. Johnston, en cambio, ni ve semejanza entre una y otras, ni está convencida de que el objeto conservado en el museo estadounidense sea una $\iota^{\prime \prime} \xi^{161}$.

La rueda de Boston, observa Karagheorgis, se parece a dos aros coronados por pájaros procedentes de Chipre y cuyas caras exteriores están pintadas con motivos geométricos del período 850-750 a.C. ${ }^{162}$ En el aro B, el mejor conservado, se aprecian siete aves con picos aplanados y anchos, como de pato, que no se corresponden con el pico corto, ligeramente curvo y en punta del torcecuello: sólo en sentido laso podríamos llamarla 'iynx-wheel'. A diferencia de las seis aves que se sientan mirando hacia fuera, hay otra que, comiendo de un cuenco con la cabeza gacha, se posa en la dirección de la circunferencia y hacia la izquierda: el detalle pudiera ser significativo. Ambas piezas se asemejan a los kernoi: vasos cultuales de base circular o anular con compartimentos donde depositar ofrendas y con figuras de animales.

En la Vida de Apolonio (post 217 d.C.) Filóstrato describe uno de los salones de la corte del rey de Babilonia. Focio tomó la descripción para ilustrar su Biblioteca:

Dicen que encontraron una estancia para hombres cuyo techo se había construido en cúpula ( $\theta$ ó $\lambda$ oৎ), representando el aspecto de un cielo, y que estaba cubierto de lapislázuli ( $\sigma \alpha \pi \varphi \varepsilon i ́ p ı v \eta \lambda i ́ \theta o \varsigma)$ - la piedra más azul y como el cielo para la vista. Las estatuas de los dioses en los que creen se levantan en lo alto, y se ven como figuras de oro, destacándose sobre el éter. Allí precisamente es donde el rey administra justicia.

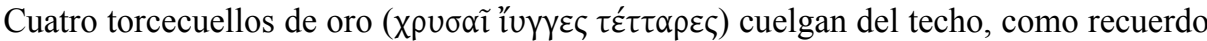
de Adrastea ${ }^{163}$, para que no se eleve sobre los hombres. Los magos ( $\mu$ ó yol) que frecuen-

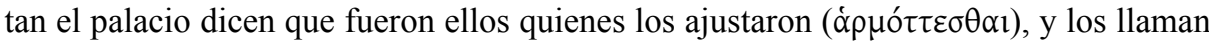
lenguas de los dioses $(\theta \varepsilon \tilde{\omega} v \gamma \lambda \tilde{\omega} \tau \tau \alpha \mathrm{l})^{164}$.

Según interpreta Johnston, las îuүyeৎ colgadas del techo del salón cumplían dos funciones: por una parte delimitaban la frontera entre el mundo inmortal (simbolizado por la cúpula celeste y las figuras de los dioses) y el mundo mortal (representado por

${ }^{160}$ The J. Paul Getty Museum, inv. 86.AE.680. Jentoft-Nilsen \& Trendall (1991: 6, 9, fig. 186). Vid. una fotografía en www.getty.edu/art/gettyguide/artObjectDetails?artobj=14945. En el ánfora 87.AE.23 (Jentoft-Nilsen \& Trendall, 1991: 16, fig. 198 y 200.4) Eros sujeta una rueda similar sobre Casiopea.

${ }^{161}$ Johnston (1990: 91, n. 4).

${ }^{162}$ Karagheorgis (1989: fig. 1-2 y 3-4). Este autor recuerda otro ejemplar de rueda estudiado por J. de La Genière, «Une roue à oiseaux du Cabinet des Médailles», REA 60 (1958): 27-35.

163 «Hija de Ananke y Zeus, está apostada en el lugar más alto como vengadora de todas las injusticias; y de los malvados ninguno hay, ni grande ni chico, que se le escape» (Plu., Mor. 564e); 'Átropo', 'Adrastea' y 'Necesidad' eran nombres del Destino (Plu., Mor. 1056c). Cf. A., Pr. 936 Page; Pl., Phdr. 248c; Arist., Mu. 401b; Ar. Did., fr. 29.6, p. 464, 28-465, 4 Diels; Plot. III, 2, 13; Herm., In Phdr. II, 40, 248c Lucarini \& Moreschini; Procl., Theol. Plat. IV, 10, p. 34, 24-35, 9 Saffrey \& Westerink; In Ti. III, p. 274, 15-23 Diehl; Dam., Pr. III, p. 161, 8-11 Westerink; Phot., Lex. a 384-385, p. 45 Theodoridis; Eust., In Il., B v. $828-834$, p. 556, 9-557, 32 Valk.

${ }^{164}$ Philostr., VA I, 25, p. 29, 1-11 Kayser; Phot., Bibl. 240, 324a, 13-24 Henry (trad. A. Bernabé Pajares, Filóstrato: Vida de Apolonio de Tiana. Madrid, 1992: 101). 
el rey y el trono); por otra, dada su posición intermedia, transmitían a los hombres las revelaciones procedentes de los dioses así como a éstos las súplicas de los hombres, favoreciendo la comunicación entre las dos regiones del universo. En vistas de que estas 'uүyع tenían que 'ajustarse, encajarse, afinarse', Johnston conjetura que debieron de ser algún tipo de mecanismo conformado por ruedas y no unas figuras de pájaros o de démones alados ${ }^{165}$. En cambio, Bernabé Pajares presumió que los torcecuellos son en realidad unos grifos ${ }^{166}$, animales fabulosos de Babilonia.

Varios detalles referidos por Filóstrato parecen repetirse en una de las visiones de Ezequiel de la merkabá o 'carro' de Dios ${ }^{167}$, acontecida según la tradición bíblica ${ }^{168}$ en Babilonia en el año 593 a.C.: el cielo de lapislázuli, el trono y, similares a las cuatro ไu $\gamma \gamma \varepsilon \varsigma$, las figuras aladas de cuatro querubines acompañadas de sendas enigmáticas ruedas. Según mi impresión, algunas imágenes de la teofanía podrían estar inspiradas en el recuerdo de un salón palaciego como el descrito en la Vida de Apolonio. Frente a quienes sostienen que el relato de Ezequiel ben Buzi, con sus iteraciones e imágenes abstrusas «hard to visualize» ${ }^{169}$, amalgama partes originarias e interpolaciones debidas a la intervención editorial de varias manos, hay quien estima que recoge la visión tal como la experimentó y relató el profeta:

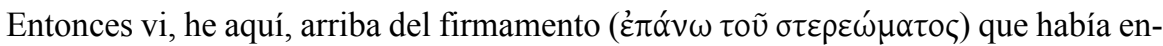

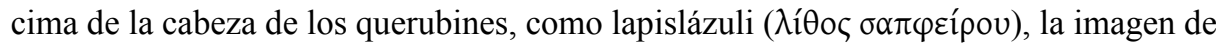

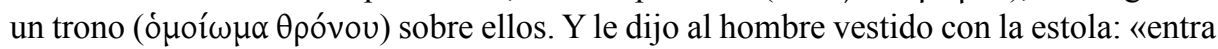

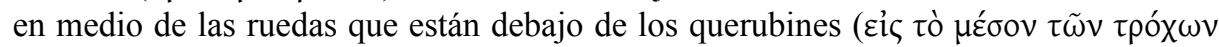

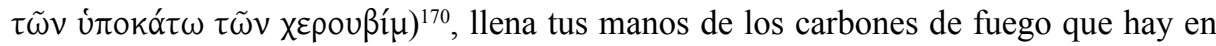
medio de los querubines (...)». Los querubines estaban de pie a la derecha de la nave (...). El ruido de las alas de los querubines se oía hasta el patio exterior (...). Él entró y se detuvo entre las ruedas (...). Entonces vi, he aquí, cuatro ruedas ( colocadas junto a los querubines, una rueda junto a cada querubín; y la apariencia de las ruedas era como la del carbón encendido $(\lambda i ́ \theta \circ \varsigma$ óv $\theta \rho \alpha \xi)$. Las cuatro tenían el mismo aspecto, como si hubiera una rueda dentro de otra rueda. Al moverse, éstas se movían en las cuatro direcciones sin dar vuelta atrás (...). Las espaldas, manos y alas (de los querubines) y las ruedas estaban llenas de ojos en derredor, las ruedas de los cuatro. A estas ruedas, pues yo lo oí, las invocaban gelgel ${ }^{171}(\ldots)$. Al moverse los querubines se movían las ruedas, éstas junto a ellos; y al desplegar los querubines sus alas para elevarse desde la tierra, las ruedas no giraban en sentido contrario; al detenerse, éstas se

${ }^{165}$ Johnston (1990: 96-97).

${ }^{166}$ Bernabé Pajares (op. cit. n. 164: 101, n. 71).

${ }^{167}$ Cf. Elior (1998: 111-112, 134-136, 154-156); Scholem (2007²); Aberbach (2007²).

${ }^{168}$ Según Goddard $(2007: 58,61)$ en Jeremías 8, 7 el término 'âgûr puede significar 'torcecuello'.

${ }^{169}$ Wood (2008: 97).

${ }^{170}$ Según Paul (20072: 600) la voz keruv (pl. keruvim) podría derivar «from Akkadian kāribu/kurību (from Akk. karābu; 'to pray', 'to bless'), an intercessor who brings the prayers of humans to the gods». En opinión de Wood (2008: 141-155), quien no comparte dicha tesis, la función originaria del querubín fue la de proteger un lugar divino, o sea, éste tuvo cualidades apotropaicas.

${ }^{171} \Gamma \varepsilon \lambda \gamma \varepsilon \lambda$ transcribe el hebreo לגלג, 'rueda, remolino'. Cf. Wood (2008: 109-110, 113). 
detenían, y al elevarse, éstas se elevaban junto con ellos, porque en ellas había espíritu de vida $(\pi v \varepsilon \tilde{v} \mu \alpha \zeta \omega \tilde{\eta} \varsigma)^{172}$.

No fue el palacio de Babilonia el único edificio antiguo de cuyo techo suspendían unas figuras tales. Filóstrato también dice que de uno de los templos de Apolo en Delfos «colgaban unos torcecuellos de oro que tenían la capacidad persuasiva propia de las Sirenas ${ }^{173}$. Las Sirenas, cuyo canto ritual se asocia al ámbito funerario, practicaron de igual manera la magia de la $\dot{\varepsilon} \pi \omega \delta \eta^{174}$. Pausanias, en Descripción de Grecia (s. II d.C.), cuenta de oídas que en el antiguo templo de Apolo en Delfos forjado en bronce hubo

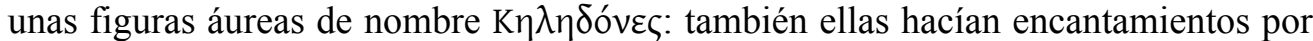
medio del canto y la palabra ${ }^{175}$. Pausanias, un tanto escéptico, confirma la noticia con el testimonio de Píndaro ${ }^{176}$ : las figuras estuvieron situadas encima del frontón. Los versos en cuestión, que Pausanias considera inspirados en el relato homérico de las Sirenas ${ }^{177}$, pertenecen a un peán pindárico hoy día fragmentario donde también se leen próximos 'Iuy[y y voós ('templo') ${ }^{178}$. Píndaro, así pues, corrobora la noticia de Filóstrato sobre los torcecuellos del templo de Apolo. A su vez, Ateneo de Náucratis

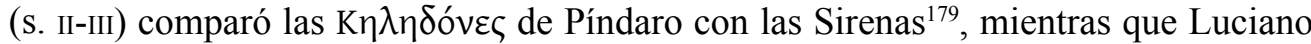
de Samósata (s. II), Sinesio de Cirene (s. IV-V) y Nicetas Coniates (s. XII-XIII) equipa-

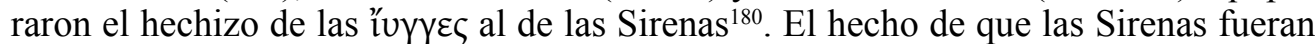
personajes híbridos con rostro de mujer y cuerpo de ave, y de que, como muestra la iconografía, tuvieran un plumaje similar al del torcecuello, pudo acentuar en el imaginario popular el parecido entre la Sirena y el ave ${ }^{181}$. Mas es cierto, como apunta Johnston ${ }^{182}$, que la capacidad persuasiva de la Sirena proviene de su voz y no de su cuerpo de pájaro. Las fuentes literarias, además, no llegan a identificar a la Sirena con la tuy ni a confundirlas.

En Sobre los sueños Sinesio asocia lacónicamente las l̈uүyes con los magos, sin que esté claro si los aludidos son los sacerdotes babilonios de Filóstrato, los teúrgos de los Oráculos caldeos, como afirma Johnston ${ }^{183}$, o algunos otros. Haciendo apología de las prácticas de adivinación tradicionales, Sinesio manifiesta que los ornito-

${ }^{172} \mathrm{LXX}, E z .10,1-17$. Sobre las dificultades textuales del pasaje hebreo y su interpretación vid. Wood (2008: 105-119, 95-104, 120-140).

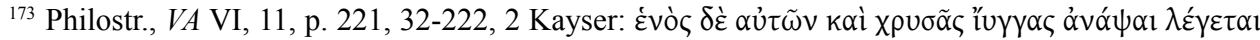

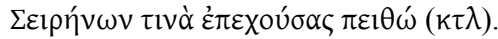

${ }^{174}$ E., Hel. 168-178 Diggle; cf. Fernández Delgado (2006: 103). Chantraine (1968-1980: 993-994) y

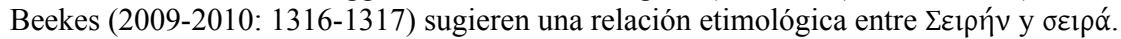

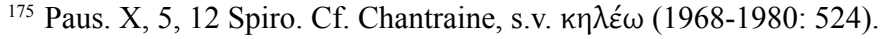

${ }_{176}$ Pi., fr. 52i, 70-71 Snell \& Maehler.

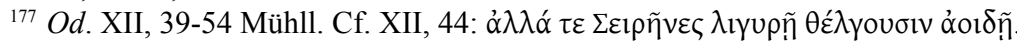

${ }^{178}$ Pi., fr. 52i, 62-63 Snell \& Maehler.

179 Ath. VII, 36, 290e, p. 141, 23-27 Kaibel (Epit. II 1, 127, 24-27 Peppink).

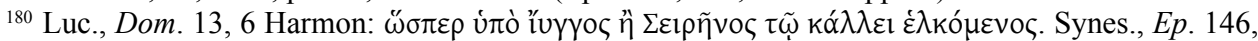

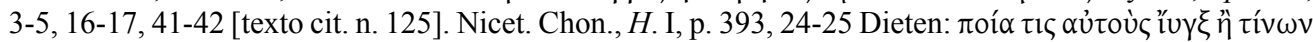

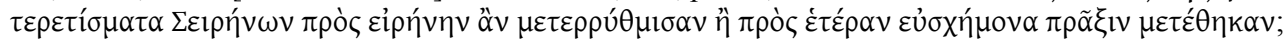

${ }^{181}$ Rodríguez López \& Pérez Suescun (1997: 56); Böhr (1997: 119-120, fig. 18).

182 Johnston (1990: 99).

183 Johnston (1990: 97). 
mantes establecen sus predicciones interpretando cual símbolos los 'gritos' ( $k \lambda \alpha \gamma \gamma \alpha i ́)$,

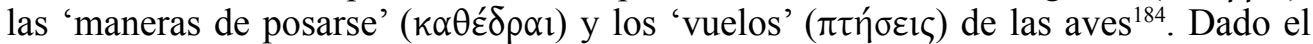

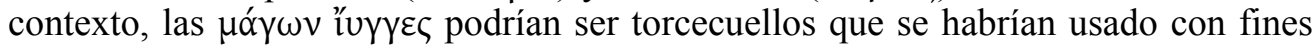
adivinatorios: ¿se observaba el comportamiento atípico del animal? Sinesio no entra

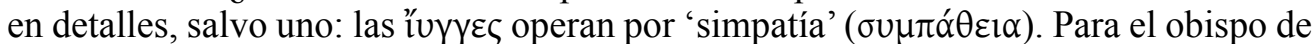
Cirene todas las cosas que participan de un mismo sonido, materia o forma matienen

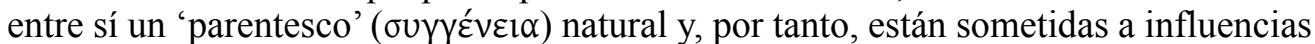

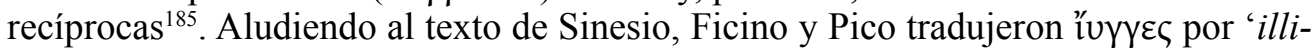
ces, illecebrae ${ }^{186}$.

La capacidad conectiva de la "uy $\langle$ se manifiesta en un pasaje de la Guerra de los judios (ca. 75-79 d.C.) donde Josefo dice que los esenios ${ }^{187}$, una vez que adoptaron «el régimen de vida introducido entre los griegos por Pitágoras ${ }^{188}{ }^{\text {, }}$ creyeron tanto en la dualidad del cuerpo y el alma como en la inmortalidad de ésta:

En efecto, entre ellos cobra fuerza la siguiente creencia: los cuerpos son corruptibles y su materia no perdura, mientras que las almas siempre permanecen inmortales y, aun cuando emanan del éter más ligero, se integran en los cuerpos, como si fueran sus

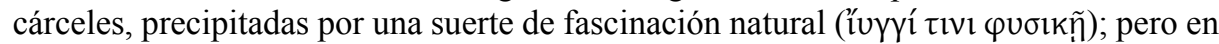
cuanto se libran de las cadenas corporales, como si en verdad fueran liberadas de una gran esclavitud, entonces se alegran y marchan a las alturas ${ }^{189}$.

La creencia de los esenios en la inmortalidad de las almas, según Josefo, era radicalmente contraria a la opinión de los saduceos, para quienes el alma muere junto con su cuerpo, y afín a la creencia farisea: el alma perdura cuando el cuerpo perece. Tanto esenios como fariseos estaban convencidos de que las almas que habían llevado una vida reprobable recibirían tras la muerte un castigo eterno, pero divergían en cuál era

${ }^{184}$ Teón de Alejandría (fl. ca. 367-383), padre de Hipatia, escribió Sobre los signos y la observación de las aves, y la voz de los cuervos (Sud., $\theta 205$ Adler), tratado hoy perdido que tal vez leyó Sinesio.

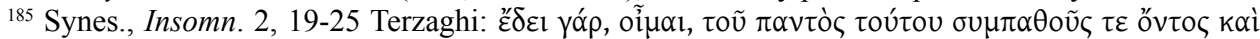

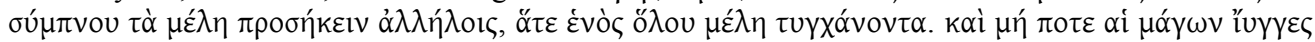

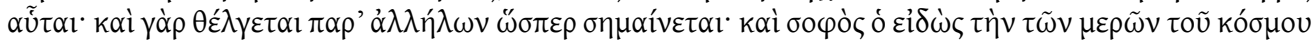

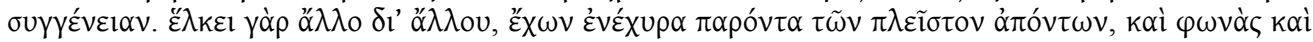

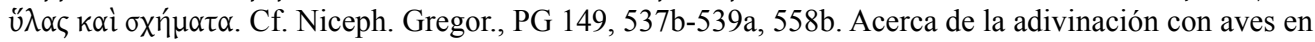
el mundo mesopotámico vid. De Zorzi (2009: 85-135).

${ }^{186}$ Ficino, De vita coelitus comparanda III, 1, 29-31 (Kaske \& Clark, 1989: 244); Picus, Oratio, 138r.

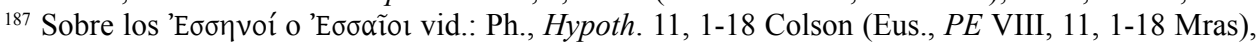
Omn. prob. lib. 75-91 (Eus., PE VIII, 12, 1-19), V. contempl. 1 Cohn \& Reiter; Plin., NH V, 17, 73 Mayhoff; I., Vit. 10, BI II, 119-161, AI XIII, 171-173, XV, 371-379 y XVIII, 18-22 Thackeray \& Marcus; Hegesipp., p. 207, 7-10 Routh (Eus., HE IV, 22, 7 Bardy); Porph., Abst. IV, 11-13 Nauck; Hippol., Haer. IX,

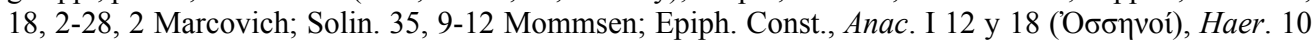
y 20, 3, 4 Holl; Synes., Dio 3, 39b Terzaghi; Cat. Act. Ap. 21, 38, p. 355, 8-12 Cramer; Const. App. VI,

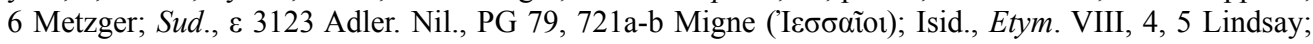
Filastr., Haer. 9 Marx; Honor. Augustud., Haer. 3 Oehler; Hieron., A. Iouin. II, 14 (PL 23, 317a Migne), Ep. 22, 35, 8 Hilberg; Mart. Cap. VI, 679 Willis. Cf. Cansdale (1997), Kottek (1997), Boccaccini (1998), Dillon (2002), Miralles Maciá (2005) y Mansoor \& Davies (2007²).

${ }^{188}$ I., AI XV, 371. Lightfoot (1892: 362-369) refutó las coincidencias entre pitagóricos y esenios.

${ }^{189}$ I., $B I$ II, 154-155. 
la recompensa reservada para las almas virtuosas: según los esenios, una vida eterna y bienaventurada en un lugar paradisíaco; según los fariseos, el regreso a la vida y a una renovada existencia corpórea ${ }^{190}$. Hipólito de Roma, en cambio, interpretó en clave

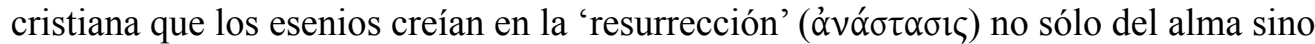
también del cuerpo ${ }^{191}$.

El caso es que Josefo, partidario del punto de vista esenio ${ }^{192}$, justifica el descenso del alma y su unión temporal con la materia mediante el ejemplo de la îuy $\xi$, un refe-

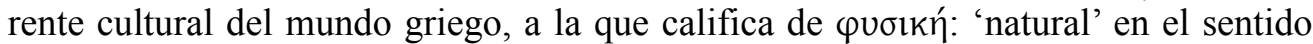
$\mathrm{de}$, tal vez, «belonging to occult laws of nature, magical» (LSJ, s.v.). Porfirio cita el pasaje de Josefo en Sobre la abstinencia: pero la tradición manuscrita sustituyó ǐuył por $\rho u ́ \mu \eta$; esta segunda significa el 'impulso' propio de un cuerpo en movimiento que, al rozar la superficie de otro, produce un susurro o murmullo iterativo, como ocurre con un batir de alas, un torno que gira, o una quilla que hiende las olas ${ }^{193}$; pareciera que ambas voces evocan imágenes sonoras comparables.

Aunque los exégetas antiguos y modernos de los Oráculos caldeos (s. II d.C.) asocian el concepto de ívүץ६ৎ a varios fragmentos $(37,75,76,77,78,82,87,108,226)$, éste sólo se atestigua en uno de autenticidad incierta (fr. 223). Kroll ya opinó: «Iyngum nomen non ex Oraculis sumptum esse, sed ab eis qui patres magicos praedicarunt contendere nolo» ${ }^{194}$. Perdidas las exégesis de los Oráculos escritas en la Antigüedad tardía, carecemos de datos para precisar en qué momento la especulación filosófica adoptó esta secular voz griega para darle un nuevo sentido: cual teónimo, casi siempre usado en plural, de unas 'Chaldaic divinities' (LSJ, s.v. '̌uy). Para indagar el des-

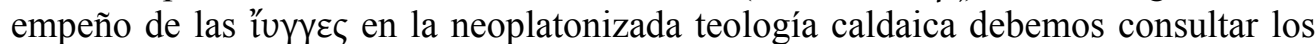
comentarios de Proclo y Damascio a los diálogos de Platón, así como los opúsculos de Pselo relativos a los Oráculos caldeos.

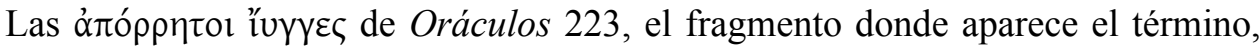
ejercen un papel similar al señalado en el texto de Josefo: permiten un vínculo entre una realidad suprasensible y otra sensible. Por medio de «encantamientos secretos»,

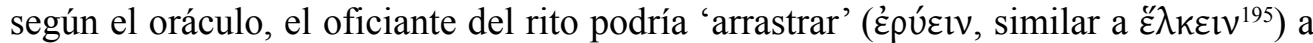
los démones aéreos y hacerlos descender a tierra ${ }^{196}$. En Sobre la filosofía de los oráculos Porfirio citó varios $\lambda$ ó $ү a$ de Hécate, entre ellos éste, con el fin de extraer una doctrina teosófica: el hombre, aunque ocupa una posición inferior en la jerarquía del ser, es capaz de constreñir a los seres divinos, superiores a él, mediante la 'fuerza de la per-

\footnotetext{
${ }^{190}$ I., AI XVIII, 14-18; BI II, 160-166 Thackeray. Cf. Mich. Syr., Chron. VI, 1 (94), p. 154-155 Chabot.

${ }^{191}$ Hippol., Haer. IX, 27 Marcovich.

${ }^{192}$ I., BI II, 158; III, 372-374 Thackeray.

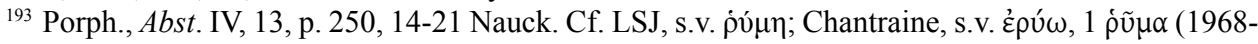
1980: 377, 979).

${ }^{194}$ Kroll (1894: 41).

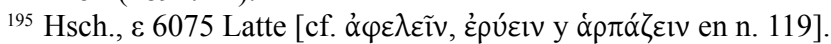

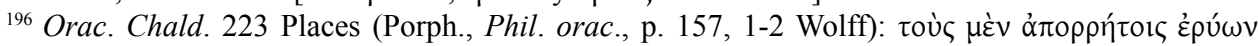

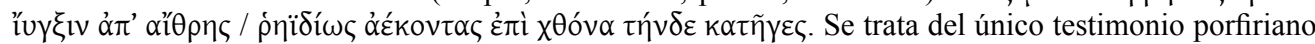
del término $̋ \nmid \gamma \xi$, el cual no se atestigua en Jámblico, Siriano, Olimpiodoro ni Simplicio.
} 


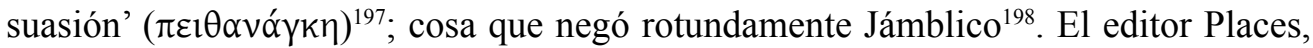
juzgando que el sentido negativo implícito en îuүye ('charmes') es impropio de los Oráculos caldeos genuinos, puso en tela de juicio el origen caldeo del fragmento ${ }^{199}$.

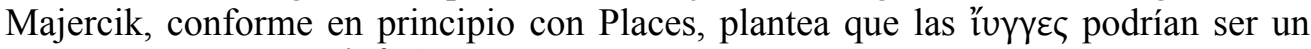
tipo concreto de los $\sigma u ́ \mu \beta o \lambda \alpha$ divinos que el Intelecto Paterno diseminó por el mundo

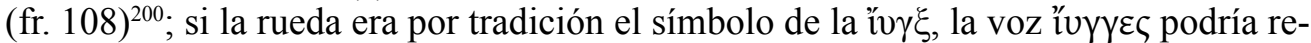

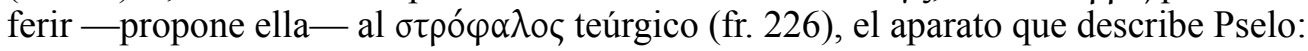

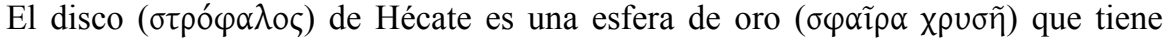

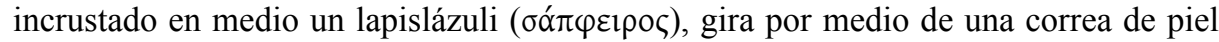

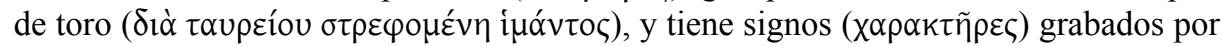

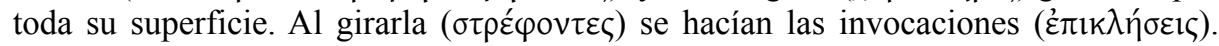
Solían también llamar a tales objetos iunges, tuviesen forma esférica, triangular o cual-

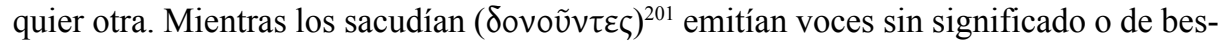

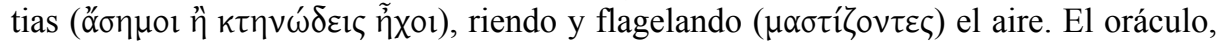
por consiguiente, enseña que el movimiento del disco indicado, dado que posee una

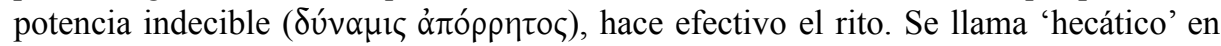
tanto que está consagrado a Hécate ${ }^{202}$.

La descripción se completa con dos noticias dadas en Proclo o Sobre la felicidad (485/486 d.C.) por Marino de Neápolis: según la primera, el maestro solía utilizar los

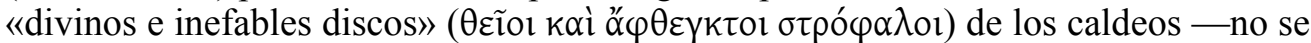
apunta el fin - en conformidad con los métodos teúrgicos que aprendió de Asclepigenia de Atenas; según la otra, podía hacer que lloviera aun en época de sequía al mover un disco al que Marino llama expresamente $\iota^{\prime} u \xi^{203}$. La proximidad fonética y semántica de las voces $\sigma \tau \rho o ́ \varphi \alpha \lambda$ ○ y $\sigma \tau \rho o ́ \beta \imath \lambda o \varsigma^{204}$ ('trompo') sugiere que entre ellas hay algún tipo de relación cuya naturaleza, empero, no está suficientemente aclarada ${ }^{205}$.

La îuy de la hechicera Nico, artilugio de magia amorosa descrito en la Antología palatina, comparte varios rasgos con el $\sigma \tau \rho o ́ \varphi \alpha \lambda o s$ teúrgico: incrustaciones de gemas, esta vez una amatista; cincelados de oro que podrían representar figuras o símbolos mágicos; y una cuerda, como es el hilo rojo de lana que se le ataba en medio ${ }^{206}$.

${ }^{197}$ Porph., Phil. orac., p. 155, 5-6 Wolff.

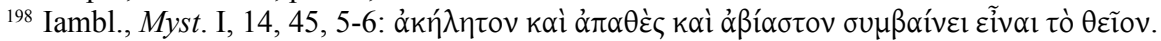

${ }^{199}$ Places $\left(2003^{4}: 20\right)$.

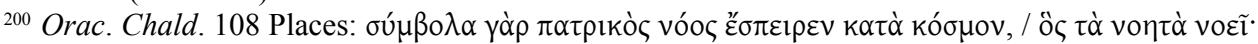

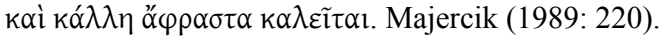

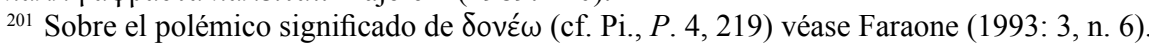

${ }^{202}$ Psel., Philos. minor. II, 38, p. 133, 17-24 O’Meara (trad. García Bazán, 1991: 140; con algunas modificaciones mías). Cf. Niceph. Gregor., Ep. 23, 105 Leone. Sobre los $\sigma \chi \eta ́ \mu \alpha \tau \alpha$ como símbolos de los dioses vid. Dam., In Prm. II, p. 100, 1-101, 14 Westerink.

${ }^{203}$ Marin., Procl. 28, 8-15 y 19-21 Saffrey \& Segonds.

${ }^{204}$ Pl., R. 436d, 5 Burnett; Plu., Lys. 12, 6 Ziegler; Hsch., $\sigma 2017$ Alpers, Erbse \& Kleinlogel.

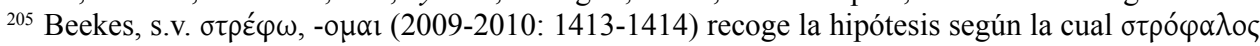

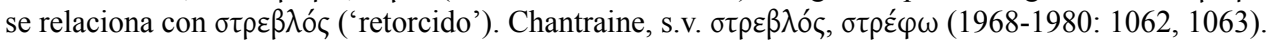

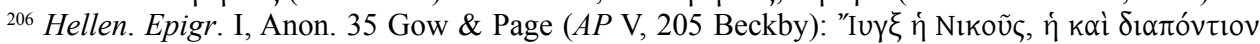

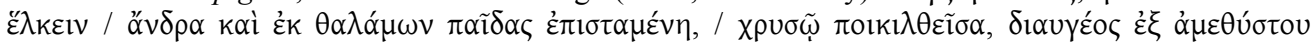


Mastrocinque estudió un conjunto de instrumentos mágicos de finales del siglo III d.C. exhumados en Pérgamo. De entre ellos destaca uno cuya forma recuerda a uno de los tipos de îuү乡 mencionado por Pselo ${ }^{207}$. El de Pérgamo tiene por base un triángulo equilátero de bronce con sendos relieves de Hécate en sus ángulos ${ }^{208}$; en el centro, un soporte; y encima se fijó un disco del mismo metal, grabado con caracteres y dividido en treinta y dos secciones. Mastrocinque interpreta que dichas divisiones son una representación esquemática de las ocho esferas del universo platónico (fijas, Saturno, Júpiter, Marte, Mercurio, Venus, Sol y Luna) y las tres Moiras o Parcas a su alrededor (en el mito de Er Cloto canta el presente, Láquesis el pasado y Átropo el futuro ${ }^{209}$. El italiano aventura que el artefacto se pudo usar en ceremonias teúrgicas para evocar a los dioses, sobre todo a Hécate, con objeto de obtener de ellos predicciones y oráculos ${ }^{210}$.

Pasemos a los Oráculos caldeos que los exégetas interpretan en alusión a las

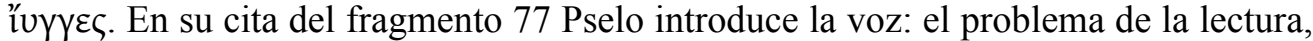
rechazada por Places, estriba en que impide la formación de un hexámetro dactílico ${ }^{211}$. Con todo, los críticos suelen opinar que el fragmento aporta el auténtico significado caldaico del término, un sentido por lo demás insólito y particularmente abstracto: las

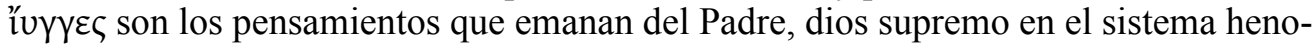
teísta caldeo (la imagen recuerda en cierto modo a la de las ǐuүyę como «lenguas de los dioses», en Filóstrato). Esta noción caldea, según mantiene Places, es un trasunto de las 'ideas' paradigmáticas del platonismo medio, equiparables a su vez a las «fórmulas seminales» que, según los estoicos, contienen en sí el germen individual de cada una de las cosas que vienen a $\operatorname{ser}^{212}$. El oráculo 77 proclama:

Las (sc. iunges) que pensadas desde el Padre piensan también por sí mismas, movidas a pensar por su voluntad inefable ${ }^{213}$.

Sin mencionar las íuүyeৎ ni aludir a ellas, Proclo parafraseó el verso primero para justificar la existencia de entidades divinas que son «inteligibles e intelectivas» (vontò

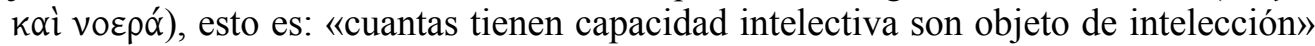

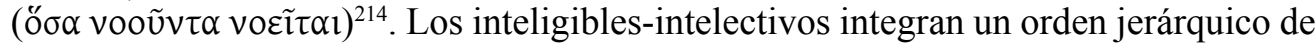

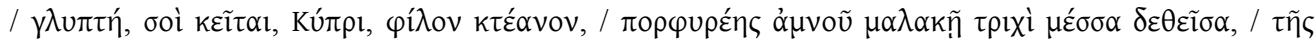

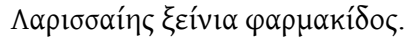

${ }^{207}$ Staatliche Museen zu Berlin, Antikensammlung, inv. 8612, 5-6. Mastrocinque (2002: fig. 3-4).

${ }^{208}$ La medida de cada uno de los lados, unos $26 \mathrm{~cm}$ (Mastrocinque, 2002: 175), coincide casualmente con la envergadura del torcecuello. El triángulo equilátero simboliza la perfección divina: Plut., Mor. 416b-f Sieveking; Procl., In Euc., p. 168, 14-17 Friedlein; Psel., Daem. 279-280 Gautier.

${ }^{209}$ Cf. Pl., R. 616b-617d, Ti. 38, b6-e3 Burnet; Hes., Th. 901-906 Mazon.

${ }^{210}$ Mastrocinque (2002: 177-184).

${ }^{211}$ Lewy (1978: 132, n. 249).

${ }^{212}$ Places (20034: 136). Cf. Orac. Chald. 37, 38 [textos cit. n. 218, 217]; Iambl., In Prm., fr. 1, 12-14 Dillon; Dam., In Prm. II, p. 46, 8-9 Westerink; SVF I, 98, 102, 497; II, 580, 717, 741, 1027, 1052, 1074 Armin.

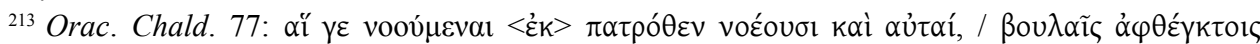

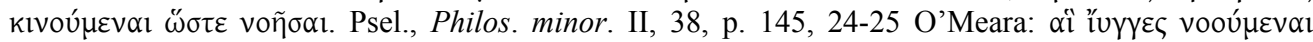

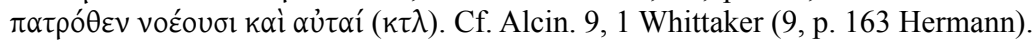

${ }^{214}$ Procl., Theol. Plat. IV, 1, p. 6, 11 Saffrey \& Westerink. 
la teología neoplatónica; por momento basta con apuntar: el hecho de que los objetos pensados por el Padre tienen género gramatical femenino, junto a la circunstancia de que - ya lo veremos- las îuүyeৎ son el primer grado de los tres que conforman el orden inteligible-intelectivo, sugieren que el oráculo 77, o al menos su exégesis, incumbía en efecto a las ǐuүyeৎ.

Así las cosas, Kroll infirió que las entidades que proceden del Padre y que corren

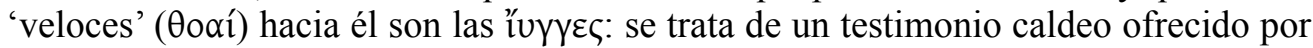
Proclo y que Taylor - a diferencia de Places y Majercik - tuvo el acierto de recoger en su recopilación de los fragmentos caldeos. En tal caso Proclo debió de juzgar que

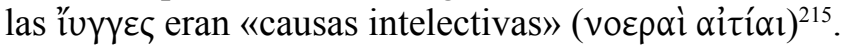

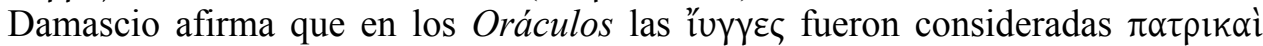

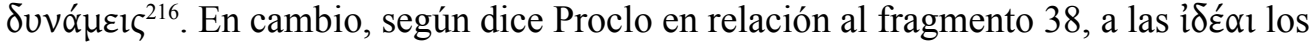

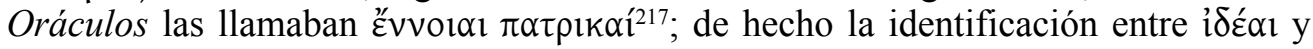
Évvold se da en el fragmento 37: el Intelecto del Padre genera las 'ideas' primigenias de todas las formas para que, una vez que han sido separadas y divididas por el Fuego

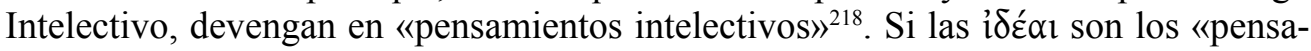
mientos paternos» que provienen del Intelecto del Padre, las ǐuүyeৎ como «potencias paternas» habrían de surgir de la Potencia del Padre (fr. 3, 4). Así pues, frente a las

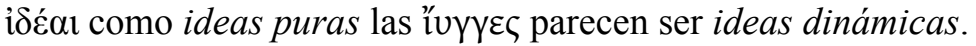

Según las Lecciones sobre el Crátilo de Proclo, el nombre de îuүyę fue revelado por la divinidad y tiene un carácter 'transmisor' $(\delta 1 \alpha \pi o ́ \rho \theta \mu 1 o v)^{219}$. Dicho en palabras de Majercik: las '̌yүeৎ «can be viewed not only as the mediators of messages, but as the message itselfi $\rangle^{220}$. Se trata entonces de una vox mystica.

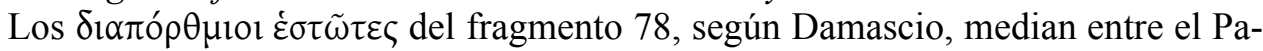
dre y la materia, eslabones primero y último en la cadena caldea del ser (fr. 173, para

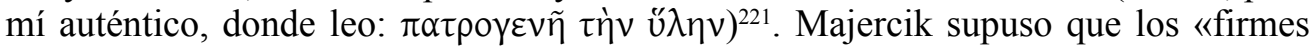

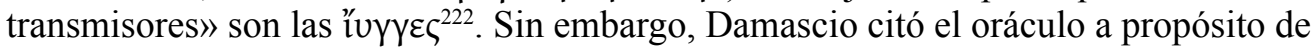

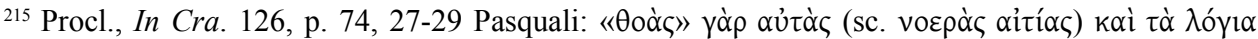

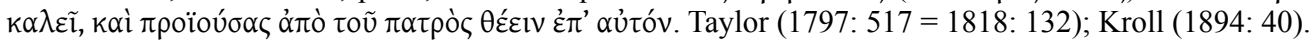

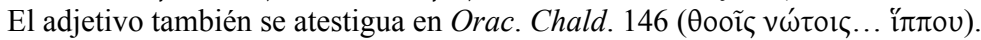

${ }^{216}$ Dam., In Prm. II, p. 42, 23-24 Westerink. Cf. II, p. 19, 2-4.

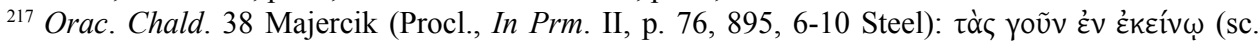

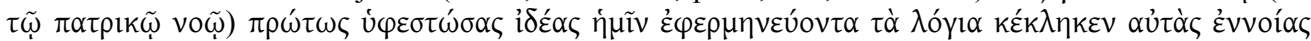

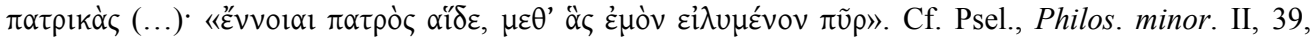

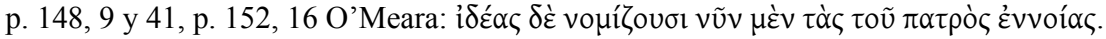

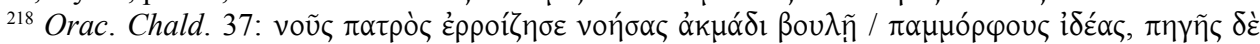

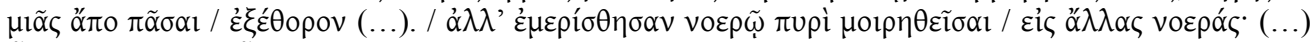

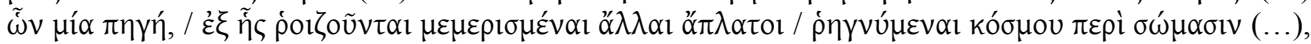

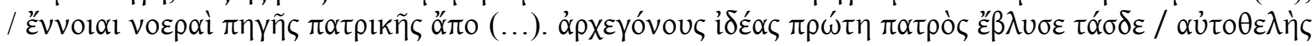

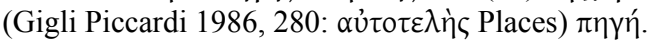

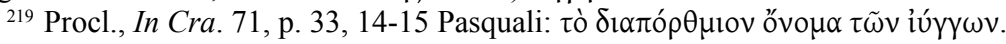

${ }^{220}$ Majercik (1989: 9).

${ }^{221}$ Fernández Fernández (2011: 251). Cf. Shaw (1995: 19-57); Hermoso Félix (2011: 45-46). Orac.

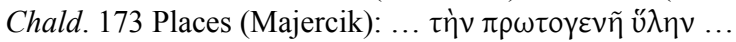

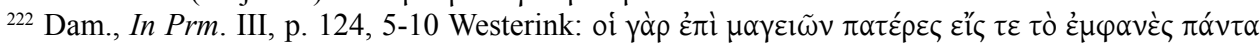

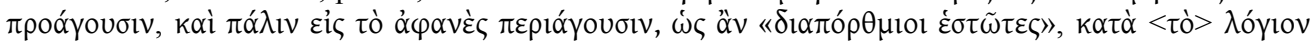




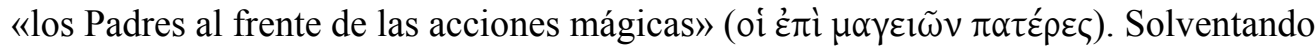
la contradicción, Johnston aventura que aquéllas y éstos son entidades equivalentes ${ }^{223}$. Pero la identificación parece errada. Juliano el Teúrgo, cuyas Cuestiones introducto-

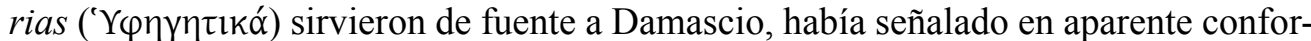
midad con la revelación divina que los Padres mágicos participan en la demiúrgia del mundo sensible; lo cual supone, como se infiere a su vez del Boceto ('Y de Pselo, que los Padres mágicos son entidades de una jerarquía inferior a la de las íuүyes. Damascio, matizando al Teúrgo, estima que los Padres mágicos reciben del

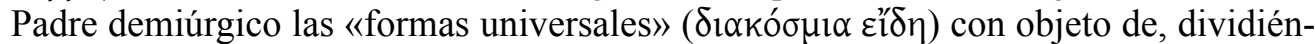
dolas y distribuyéndolas, conformar los seres particulares y sensibles ${ }^{224}$. En conformidad con el fragmento 77 y su exégesis, interpreto que los Padres mágicos —ausentes en la edición crítica de Places - reciben las î́үyeৎ cual pensamientos, ideas o formas, según dijimos dinámicos, que nacen del Padre.

La definición de demon del Banquete platónico arroja luz sobre el Oráculo 78: lo demónico «interpreta y transmite ( $\delta 1 \alpha \pi \circ \rho \theta \mu \varepsilon \tilde{v} o v)$ a los dioses los asuntos de los hombres y a los hombres los de los dioses (...). Al estar en medio de unos y otros colma el espacio que hay entre ambos, de modo que el universo mismo queda atado consigo mismo» ${ }^{225}$. Luego las ǐuүүદৎ, en su papel transmisor, actuarían como démones. Los démones, continúa Platón, hacen posible las prácticas adivinatorias, sacerdotales y mágicas, ejecutando por ejemplo los 'encantamientos' ( $\dot{\varepsilon} \pi \omega \delta \alpha \hat{i})$; Eros es un demon destacado. Planteadas así las cosas, Majercik infiere que «under the influence of Plato's spiritualization of Eros, the word Iynx came to mean the 'binding'force between man and the gods» ${ }^{226}$. Johnston, en la misma línea, sostuvo que las íuүyeৎ demónicas son el resultado de una síntesis de filosofía platónica sobre el demon y de magia simpática $^{227}$. No obstante, recordemos que ya antes de Platón la voz ǐuył solía expresar una fuerza de atracción, mayormente erótica, entre dos seres del reino natural. Aunque la influencia platónica resulta verosímil, lo cierto es que en los Oráculos las ǐuүүદৎ no suplantan a Eros, al que se asigna una función bastante definida: el Intelecto Paterno diseminó «el lazo de Eros» entre todos los seres que forman el mundo para que se

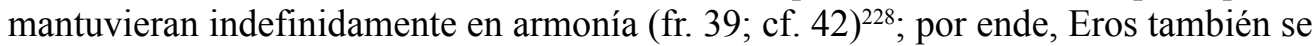
asienta en el alma del hombre, donde se une al intelecto y la voluntad para formar una tríada de origen divino: Eros, a la vez que da cohesión interna a la terna, conecta el

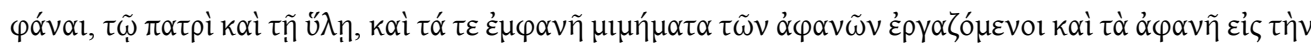

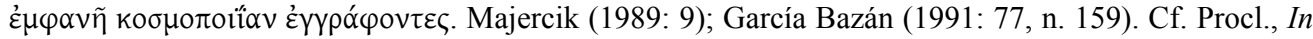
Prm. III, p. 216, 1199, 27-28 Steel.

${ }^{223}$ Johnston (1990: 92).

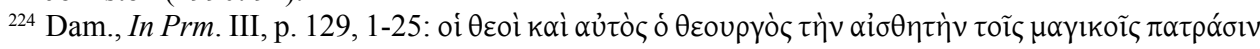

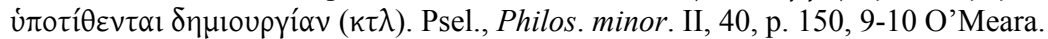

${ }^{225}$ Pl., Smp. 202e-203a Burnet. Cf. Iambl., Myst. I, 5, 16, 13-17, 7 Places.

${ }^{226}$ Majercik (1989: 9).

227 Johnston (1990: 110).

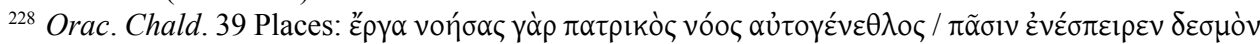

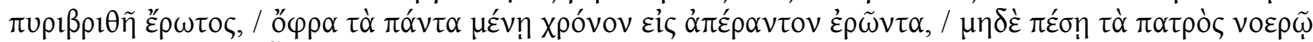

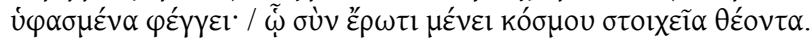


alma con los restantes seres del universo (fr. 44) ${ }^{229}$; Eros, junto con la fe y la verdad, es una de las tres virtudes que, por ser primigenias, purifican el alma y la elevan en su retorno al mundo divino (fr. 46; cf. 43, 45) ${ }^{230}$.

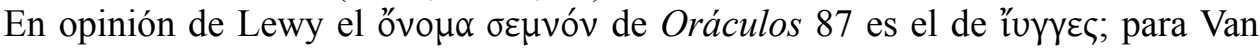
Liefferinge, empero, el de П $\alpha \tau \eta ́ p$, en referencia al dios caldeo superior ${ }^{231}$. Proclo citó el oráculo en Lecturas del Crátilo, donde debate antiguas posturas teóricas en torno a si los nombres son por convención (la tesis de Hermógenes) o por naturaleza (la tesis de Crátilo): según Proclo, el «nombre venerable» es el que se adecua plenamente a la cosa designada porque fue asignado a ella por el Demiurgo ${ }^{232}$; los nombres venerables son pues por naturaleza, tesis a la que se adhiere Proclo. También evoca el oráculo en Sobre el Alcibíades: todos los «nombres inefables» de los dioses y las potencias divi-

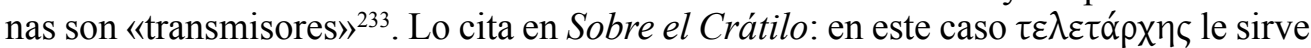

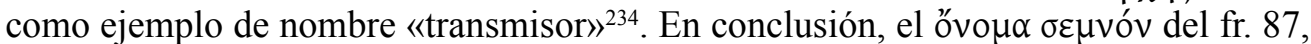
según las varias explicaciones dadas por Proclo, tiene un sentido genérico y no alude a un nombre divino concreto. Ahora bien, dado que este nombre desciende, según

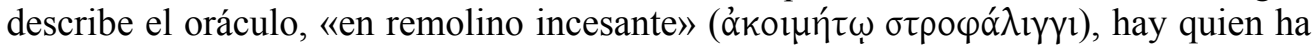
asociado la imagen sonoro-visual al $\sigma \tau \rho o ́ \varphi \alpha \lambda$ os de Hécate y, por ende, mantenido que el nombre en cuestión es en efecto ǐvүyع $\varsigma^{235}$.

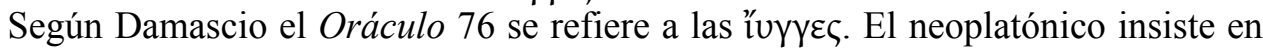
que no hay que confundir el que son «muchas, una pluralidad», con el hecho de que ellas dependen de otras tres denominadas 'cimas' por su grado mayor de perfección: según la reconstrucción del oráculo propuesta por Lewy, una cima es ígnea, otra etérea

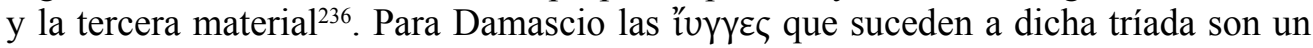
total de siete, en correspondencia con los «mundos brillantes» y, al parecer, las esferas

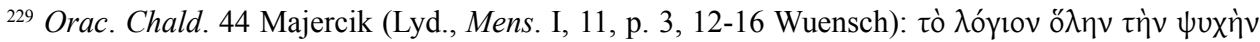

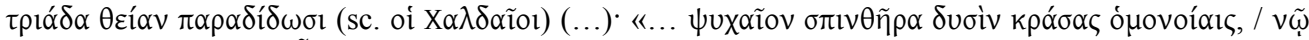

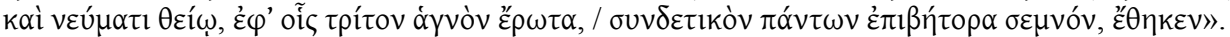

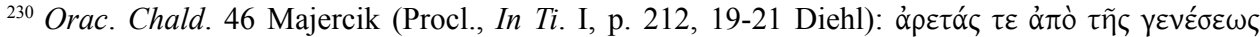

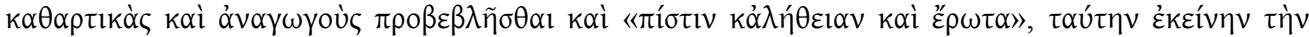
$\tau \rho l \alpha ́ \delta \alpha$. Cf. Psel., Philos. minor. II, 38, p. 136, 19-20; 40, p. 149, 30-150, 1 O’Meara. Sobre el Eros caldeo vid. Lanzi (2006: 43-44).

${ }^{231}$ Orac. Chald. 87 [texto cit. n. 232, 233]. Lewy (1978: 134); Van Liefferinge (1999: 135).

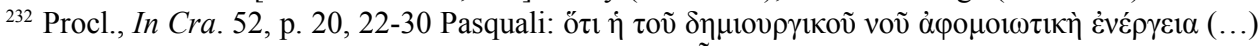

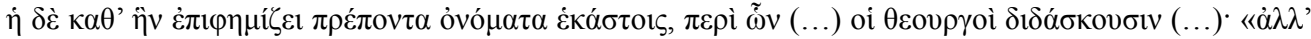

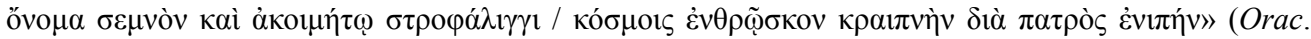
Chald. 87). Cf. 51, p. 20, 1-16; Iambl., Myst. VII, 5, 257.

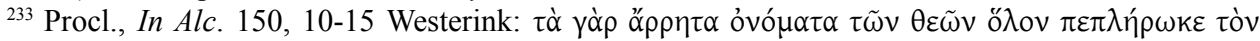

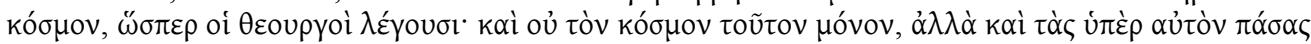

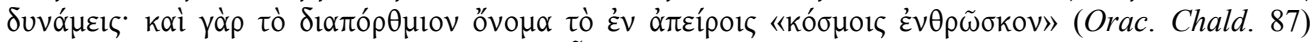

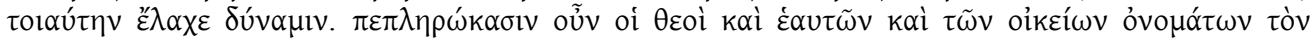
$\sigma u ́ \mu \pi \alpha v \tau \alpha$ kó $\mu$ ov.

${ }^{234}$ Procl., In Cra. 71, p. 33, 15-17 Pasquali.

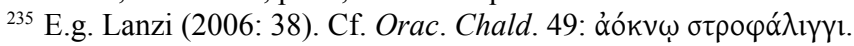

${ }^{236}$ Orac. Chald. 76 Majercik (Dam., In Prm. II, p. 34, 18-22 Westerink; cf. I, p. 94, 18-22): ónoíws

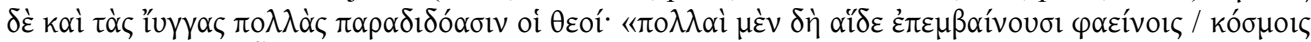

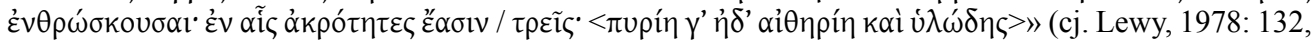
n. 250 ex Procl., In Ti. II, p. 57, 10-12). Cf. Dam., In Prm. II, p. 31, 24-25; p. 34, 3-6; Psel., Philos. mi- 
planetarias ${ }^{237}$. Damascio ratifica la conjetura de Lewy: hay una $\left.{ }^{\prime \prime} u\right\} \xi$ fontanal, cual mónada al frente de la tríada de ľvүץєৎ, que organiza el universo caldeo en tres tipos de realidad: a la ı̌vy primera corresponde el mundo empíreo (o inteligible); a la central el etéreo (las estrellas y los planetas); y a la final el material (o ámbito sublunar, que incluye la Tierra); Pselo, a su vez, identifica los tres mundos con los siete firmamentos

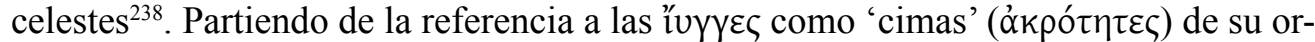
den, Westerink justifica que Proclo haya inducido que ellas son «divinidad que reúne

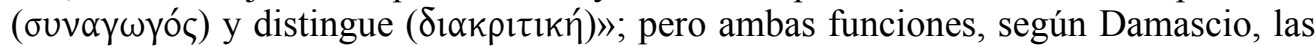
realizan no tanto por ser 'cimas' sino potencias mediadoras ( $\mu \varepsilon \sigma o ́ \tau \eta \varsigma, ~ \delta u ́ v \alpha \mu l \varsigma)^{239}$.

Citado a continuación del fragmento 76, el Oráculo 75 alude por consiguiente a las îuүץє y no, como se creyó por un corte falso o error al puntuar ${ }^{240}$, a los Teletarcas:

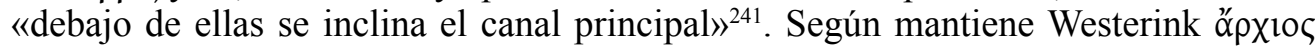
alude a los dioses ả $\rho x \alpha i ́$ del orden hipercósmico ${ }^{242}$; pero la solución, admisible en relación a Damascio, no explica el oscuro fragmento: en los Oráculos no se atestigua ese tipo de dioses. En opinión de García Bazán el fragmento tiene que ver con el «princi-

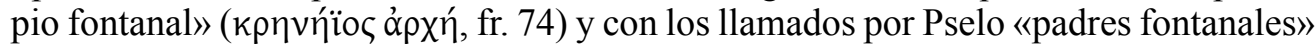

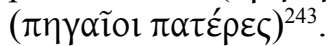

La teología neoplatónica sistematizó diferentes órdenes en respuesta positiva a la segunda hipótesis del Parménides (142, b1-155, e3) que plantea: si lo Uno es, ¿qué consecuencias se derivan para lo Uno? Partiendo del diálogo platónico Proclo y Damascio establecieron la siguiente jerarquía divina ${ }^{244}$ : orden inteligible (142, b5-143, a3); orden inteligible-intelectivo (143, a4-145, b5); orden intelectivo (145, b6-146, d1), integrado por una hebdómada; orden hipercósmico (147, c1-149, d7); y orden encósmico (149, d8-155, d5), que incluye: dioses celestes no-errantes, dioses celestes errantes, dioses sublunares, almas universales, así como ángeles, démones y héroes (estos tres son, en relación a las almas humanas, los géneros superiores).

El orden asociado por Damascio a las íuүyeৎ es el inteligible-intelectivo. En él es donde se manifiestan los «símbolos sagrados» (i $\varepsilon \rho \alpha ̀$ $\sigma u v \theta \eta \dot{\mu} \mu \alpha \tau \alpha, \sigma u ́ \mu \beta o \lambda \alpha \theta \varepsilon \tilde{\omega} v$ ) que los dioses transmitieron a los teúrgos ${ }^{245}$ : uno de estos símbolos son las ǐuүyec. Según Damascio el orden inteligible-intelectivo es resultado de la aserción de Platón: «lo Uno en sí, al estar fragmentado por el ser, es pluralidad y multiplicidad ilimitada»

nor. II, 40, p. 149, 2-5 O’Meara; Oxford, Bodleian Library, ms. Barocci 181, 17 (cita Kroll, 1894: 39-40); Majercik (1989: 171-172).

${ }^{237}$ Dam., In Prm. II, p. 34, 3-4 Westerink.

${ }^{238}$ Dam., In Prm. II, p. 35, 19-26, p. 47, 15-19; Psel., Philos. minor. II, 40, p. 149, 2-5 O’Meara. Majercik (1989: 16-19) resume la cosmología caldea.

${ }^{239}$ Dam., In Prm. II, p. 2, 22-24, p. 20, $13-17$ (con comentario en p. 112-113). Cf. Kroll (1894: 40).

${ }^{240}$ Lewy (1978: 141, n. 281); Places (20034: 136).

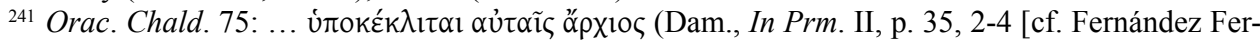

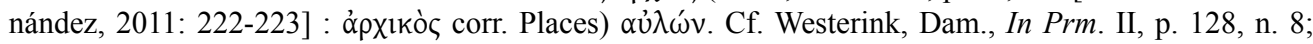
Majercik (1989: 171); García Bazán (1991: 76, n. 154); Fernández Fernández (2011: 263).

${ }^{242}$ Westerink, Dam., In Prm. II, p. 122. Cf. Kroll (1894: 38).

${ }^{243}$ García Bazán (1991: 76, n. 152-154).

${ }^{244}$ Saffrey \& Westerink, Procl., Theol. Plat. I, p. LX-LXXXIX; Westerink, Dam., In Prm. I, p. XXXIII-XXXVII.

${ }^{245}$ Dam., In Prm. II, p. 45, 21-46, 2. Johnston (1990: 91, n. 4). Cf. Procl., Phil. Chal. 5 Places. 
(Prm. 144e, 3-5); en cambio, según informa Damascio, Proclo había derivado este orden de otra proposición cercana: «dado que las partes son partes de un todo, lo Uno, en tanto que todo, sería limitado» $(144 \mathrm{e}, 8-9)^{246}$. Damascio, al incidir en la multiplicidad como atributo de lo Uno, destacó el surgimiento del número y la pluralidad: las

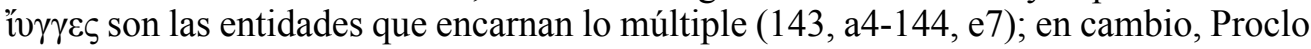
puso la atención en las partes inherentes a lo Uno en cuanto todo limitado y del que provienen las partes ilimitadas de la multiplicidad: en la Teología platónica ${ }^{247}$, donde

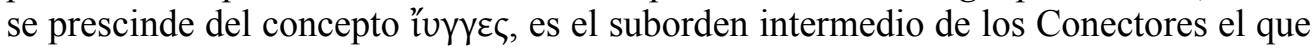
da cuenta de lo múltiple, las partes y lo ilimitado (144, e8-145, a4).

En la metafísica de Damascio las "uyүes constituyen el grado primero del orden inteligible-intelectivo. En la discusión del suborden de las "úvүعৎ el filósofo plantea la cuestión: «¿cómo es que la identidad no se opone a la alteridad y produce la pluralidad inteligible, así como la alteridad produce el número?» ${ }^{248}$. La respuesta se desarrolla en torno a dos series de conceptos contrarios: por un lado, 'identidad' ( $\tau \alpha u ̛ \tau o ́ \tau \eta \varsigma)$,

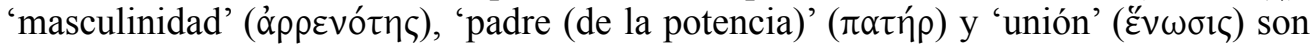

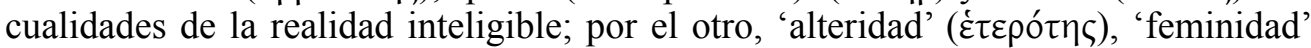

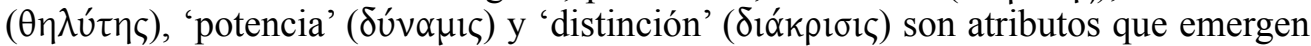

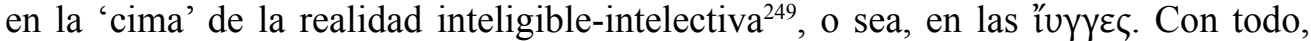
Damascio concluye que dichas oposiciones no se dan del todo en este suborden: «las luүyes, en efecto, tienen carácter paternal, como atestiguan los Oráculos, si bien también son llamadas potencias del Padre ${ }^{250}$. Haciendo síntesis de tradiciones teológicas, el de Damasco equipara las tres 'uүyes caldeas a las Noches de los órficos por ser

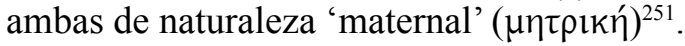

En correspondencia con el sistema teológico de Proclo y Damascio, los resúmenes de la teología caldea transmitidos por Pselo distinguen los mismos tres 'órdenes'

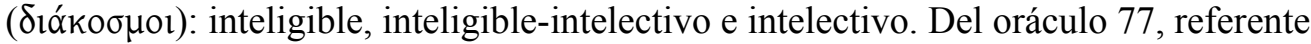

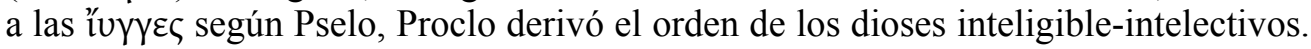
Damascio, por su parte, justifica la existencia de dicho orden segundo e intermedio mediante el oráculo que asevera ${ }^{252}$ : en toda ordenación hay por fuerza un «principio, término y medio» (fr. 24); la revelación, en opinión de Damascio, atañe a la ley de continuidad. Cabe relacionar este dogma caldeo con aquel otro según el cual la realidad se estructura en tríadas (fr. 22, 27) ${ }^{253}$.

${ }^{246}$ Dam., In Prm. II, p. 86, 12-87, 16. Cf. Procl., Theol. Plat. IV, 28, p. 80, 24-34, p. 95, 13.

${ }^{247}$ Procl., Theol. Plat. IV, 35, p. 127, 9-36, p. 133, 28.

${ }^{248}$ Dam., In Prm. II, p. 1, 20-21.

${ }^{249}$ Dam., In Prm. II, p. 18, 6-21, 14 (cf. II, p. 2, 22-3, 7).

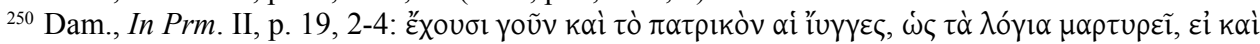

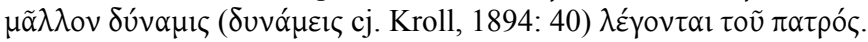

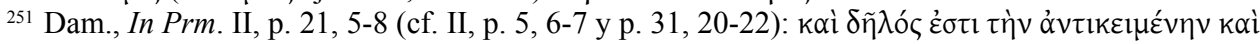

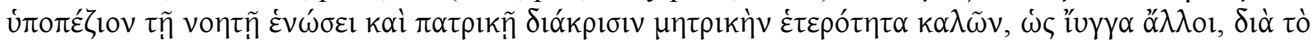

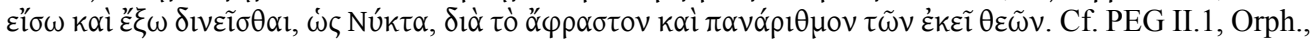
147 F Bernabé (fr. 99 Kern).

${ }^{252}$ Dam., Pr. III, p. 118, 14 Westerink. Cf. Procl., Inst. 132 Dodds.

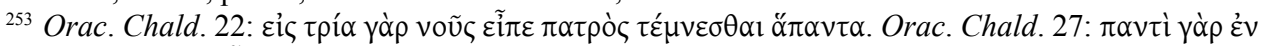

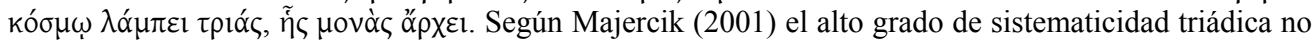
es originario de los Oráculos. Cf. Procl., Inst. 148, p. 130; 103, p. 92, 18-20. 
En el primer orden Pselo define tres rangos: lo Uno-Bien, que es principio único (cf. «Principio paterno», fr. 13) y causa primera; el Abismo paterno (fr. 18); y una tríada paterna inteligible formada por Padre, Potencia e Intelecto (cf. fr. 4, 5, 37). La realidad 'inteligible' (vontós) comienza propiamente en el nivel tercero, separada de la realidad inefabilísima de lo Uno por un Abismo lleno de silencio. De la tríada, como ya hiciera Proclo, Pselo extrae una enéada de tres tríadas paternas inteligibles, en cada una de las cuales prevalece un elemento: Padre, Potencia, Intelecto; Padre, Potencia, Intelecto; Padre, Potencia, Intelecto (a toda potencia, comenta Proclo al citar el fr. 4, corresponde siempre ocupar una posición intermedia por ser la facultad que define a los démones y las entidades mediadoras ${ }^{254}$ ).

Según Damascio, los teúrgos instituyeron tres tríadas en «lo inteligible» ( $\dot{\varepsilon} \vee \tau \tilde{\omega}$

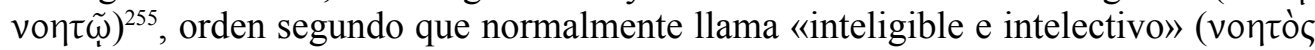

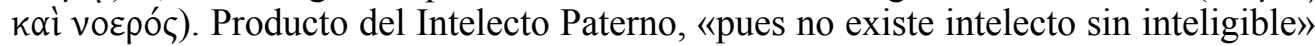

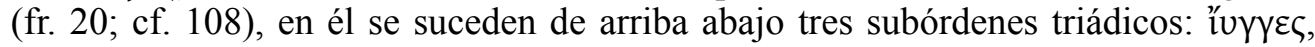

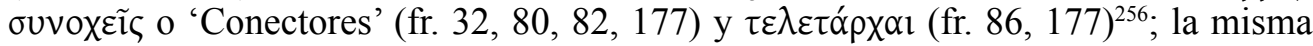
disposición se repite en los resúmenes caldaicos de Pselo. Damascio, jugando con el sistematismo triádico de Proclo, propone que las tres tríadas paternas inteligibles deben de estar gobernadas por mónadas cuyas naturalezas corresponden, respectivamente, a la del elemento que predomina en la tríada: una mónada paterna rige pues la tríada Padre, Potencia e Intelecto, así como una mónada potencial y una mónada inteligible rigen las otras dos tríadas. Llegado a este punto, Damascio establece una correspondencia entre cada una de las mónadas del orden inteligible (o sea, el término dominante de cada tríada paterna inteligible) y cada una de las tríadas del orden inteligible-intelectivo: en consecuencia, la naturaleza de la $\iota^{\prime} u y \xi$ resulta paterna; la del Conector, potencial; la del Teletarca, intelectiva. Además, si las ǐuүyę forman una tríada y hay una ı̌uy paterna, la compleción de la tríada requiere que en ella también subsistan las naturalezas de las otras dos mónadas: la segunda î́vł sería potencial y la tercera inteligible (igual sucede en la tríada de Conectores y la tríada de Teletarcas) ${ }^{257}$. Las İuүyes, tríada primera del orden, reciben del Intelecto Paterno inmediatamente

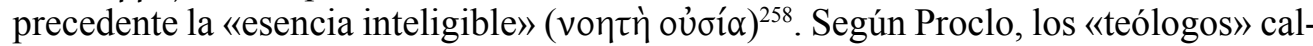
deos ya asignaron al orden inteligible la «potencia transmisora» ${ }^{259}$ atribuible, según

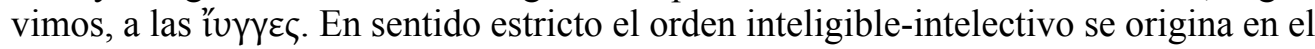

${ }^{254}$ Procl., In Alc. 84, 11-14 Westerink. Cf. Theol. Plat. III, 8, p. 31, 20-23 Saffrey \& Westerink.

${ }^{255}$ Dam., Pr. III, p. 109, 4-5 y 15-16; p. 119, 3-6. Cf. Procl., In Cra. 122, p. 72, $10-12$ Pasqually.

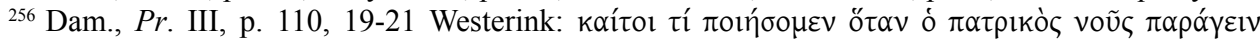

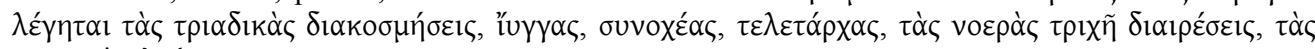

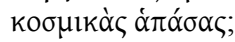

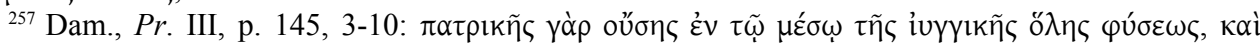

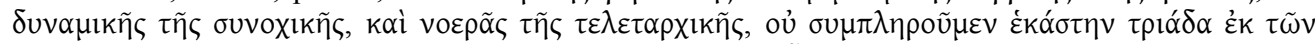

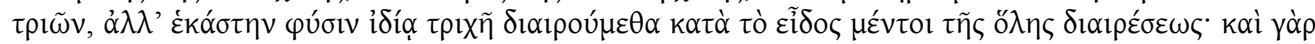

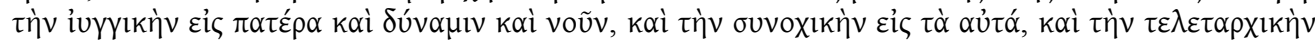
ópoíws.

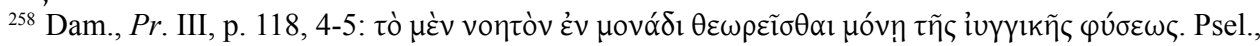

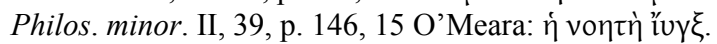

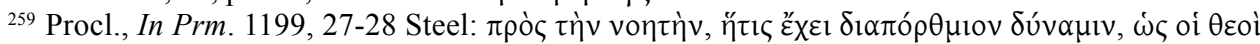
$\lambda$ غ́үovol. 
suborden segundo de los Conectores: esta tríada, desde su posición central, permite la continuidad entre las îuүyeৎ superiores y los Teletarcas inferiores ${ }^{260}$.

El orden 'intelectivo' (voepó $)$, el tercero, está conformado por los llamados «pa-

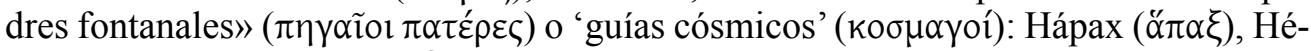

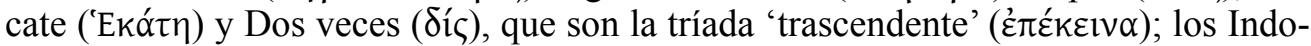

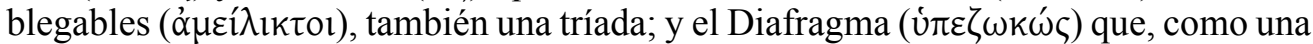
membrana, separa los órdenes inteligibles e intelectivos de los órdenes hipercósmico y cósmico, inferiores. No parece que dicha hebdómada, como alguna vez se ha sugerido,

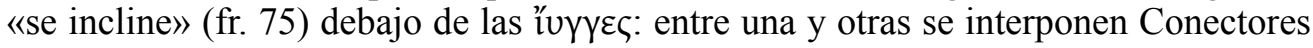
y Teletarcas.

Frente a la teoría neoplatónica de las íuүyę, que se inserta en un entramado conceptual complejo y elaborado, Johnston simplificó como sigue la función de estas entidades en el sistema primigenio de los $\operatorname{Oráculos}^{261}$ : primero Hécate, asimilada al Alma cósmica (fr. 53) ${ }^{262}$, recibe del Intelecto del Padre las íuүyeৎ ('ideas, símbolos' del mundo noético) para, en su papel de entidad demónica, transmitirlas al mundo físico y darlas en revelación al hombre; a continuación, y con objeto de erigir un puente

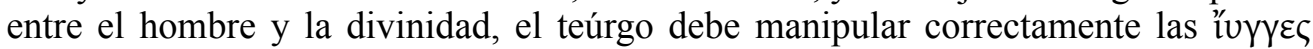
como símbolos, asistido por la diosa misma. Las îuүyeৎ son entidades teúrgicas ex

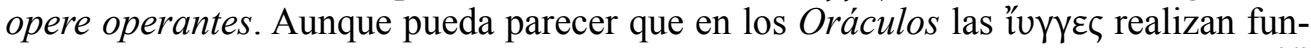
ciones confusas, ellas siempre actúan, resuelve Majercik, como «'binding' entities» ${ }^{263}$ que median entre el mundo inteligible y el mundo sensible. Los investigadores sostienen que la voz tuvo un doble significado en los Oráculos caldeos ${ }^{264}$ : por un lado, las "uүүeৎ eran los «pensamientos pensantes» (fr. 77), o si se quiere las 'ideas' (fr. 37), que el Intelecto del Padre diseminó por el universo; por el otro, las îuүyę fueron un instrumento y un símbolo (cf. fr. 206; 223, de dudoso origen caldeo). Según interpreta Johnston, ambas nociones a primera vista inconexas expresan dos caras de un mismo

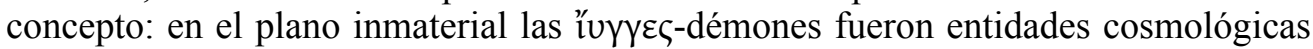
que desempeñaban una función congruente con la naturaleza conectiva y transmisora

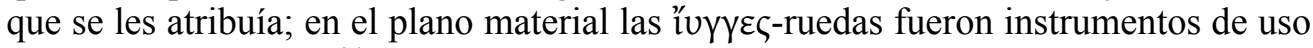
en prácticas teúrgicas ${ }^{265}$. El teúrgo, anticipaba Majercik, se habría servido de unas y otras para comunicarse con su dios Padre: al hacer girar la rueda ı̌vył atraía por sim-

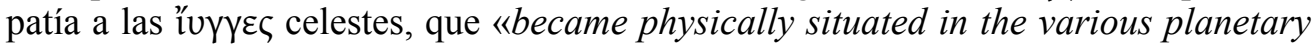
spheres» ${ }^{266}$. Moutsopuolos, de modo independiente, formuló una tesis similar: «sur le plan cosmologique, les iynges sont des principes ontologiques et, de ce fait, des principes aptes à véhiculer la musicalité même de l'univers. Par contre, sur le plan oraculaire à proprement parler, le terme d'iynge désigne un élément entièrement intégré dans certaines pratiques magico-mystiques» ${ }^{267}$.

\footnotetext{
${ }^{260}$ Dam., Pr. III, p. 117, 5-15 Westerink. Cf. Orac. Chald. 177.

261 Johnston (1990: 107-110).

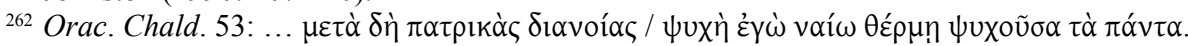

263 Majercik (1989: 9).

264 E.g. Lewy (1978: 132-134); Duffy (1995: 85).

265 Johnston (1990: 106).

${ }^{266}$ Majercik (1989: 10).

${ }^{267}$ Moutsopoulos (1990: 290-291).
} 
En conformidad con los textos neoplatónicos recogidos y comentados, también puede parecer que el concepto metafísico de ǐuүyeৎ no tiene relación alguna con las

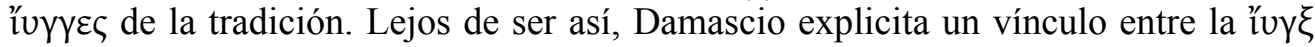
neoplatónica y dos sentidos que se asociaban por lo común al término îuүy:

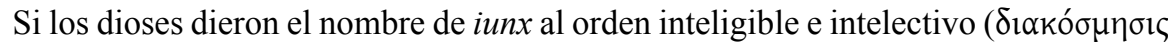

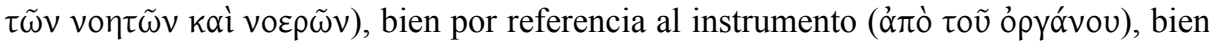

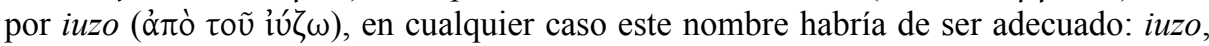
por ser una voz entusiástica que termina en un tono agudo; el instrumento, por la idea de que actúa sobre todas las cosas de manera inefable e instantánea: y es que la iunx multiplica rápido sus propios productos y una vez soltados los recoge en sí (por ello se dice que incluso arrebata las almas hacia lo alto), pues también el instrumento al girar hacia dentro ( $\left.\sigma \tau \varepsilon \varepsilon \varphi o_{\mu \varepsilon v o v} \varepsilon \ell^{\prime} \sigma \omega\right)$ invoca a los dioses, mientras que hacia fuera $(\xi \xi \xi \omega)^{268}$ despide a los invocados ${ }^{269}$.

Al extrapolar al pasaje la teoría del símbolo en Jámblico expuesta por Hermoso Félix, se deriva que las ǐuүyę cumplían una doble función simbólica: el instrumento, por la semejanza física, actuaba como un símbolo analógico, mientras que la palabra "uył que lo designa, por ser una voz mística con un sonoridad particular, servía como un símbolo unitivo $^{270}$. Sirva como precedente el juicio de Lewy: «we may accordingly suppose that when the magical instrument was set in motion, it affected per analogiam the revolving spheres and attracted the celestial Iynges» ${ }^{271}$. Partiendo de la teoría de la imaginación simbólica y del método arquetipológico de Durand, hay quienes mantie-

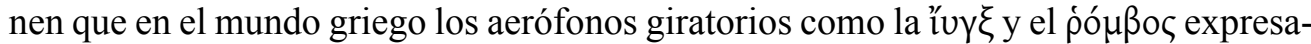
ron con sus sonidos propios el arquetipo de la espiral cósmica ${ }^{272}$, que a su vez simboliza la creación del mundo: sus timbres habrían actuado como $\left\langle\right.$ creative agency» ${ }^{273}$. En los bullroarers o 'bramaderas', cuyo uso remonta al Paleolítico Superior (por ejemplo, en la cultura magdaleniense) y cuyo modelo más conocido hoy día es el turndun de los aborígenes de Australia ${ }^{274}$, se interfieren dos sonidos originados por un doble

${ }^{268}$ Cf. Dam., In Prm. II, p. 21, 7-8 [texto cit. n. 251].

${ }^{269}$ Dam., In Prm. II, p. 47, 5-13. Para mayor claridad de la trad. he alterado el orden de varias frases.

${ }^{270}$ Hermoso Félix (2011: 42-66).

${ }^{271}$ Lewy (1978: 250), también citado en Majercik (1989: 215) y Lanzi (2006: 38, n. 12).

${ }^{272}$ Según Durand (2004: 335) el patrón de la espiral se define como «un equilibrio dinámico». En otra parte (1971: 17) observa: «Mediante este poder de repetir, el símbolo satisface de manera indefinida su inadecuación fundamental. Pero esta repetición no es tautológica, sino perfeccionante, merced a aproximaciones acumuladas. A este respecto es comparable a una espiral, o mejor dicho a un solenoide, que en cada repetición circunscribe más su enfoque, su centro. No es que un solo símbolo no sea tan significativo como todos los demás, sino que el conjunto de todos los símbolos relativos a un tema los esclarece entre sí, les agrega una 'potencia' simbólica suplementaria».

${ }^{273}$ Hagens (2005: 3). Cf. Salvatore (1991: 19).

${ }^{274}$ Morley (2003: 33-37). Gow (1934: 5) y Tufnell (1983: 66) mencionan el ferneyny, juguete de los niños beduinos de Al-Ḥarrā' (Arabia) que, según documenta Doughty (1888: vol. I, 433), giraba y zumbaba por acción de una cuerda doble; éste se parece, apunta Bynon (1987: 168, n. 33), al tasbarrayt del centro de Marruecos. Simpson (1896: 164) cita la î $\gamma \xi \xi$ en su trabajo sobre la mani-chos-'khor o 'rueda de plegaria' de los budistas tibetanos. 
movimiento, como explica Salvatore: la cuerda, al girar en el aire trazando un plano circular, produce un silbo agudo, mientras que el husillo, al girar sobre su propio eje, emite un zumbido o tono bajo ${ }^{275}$. El musicólogo piensa que la $\iota^{\prime} v \gamma \xi$ se pudo confundir con el $\rho$ ó $\mu \beta{ }^{276}{ }^{276}$ porque los dos hacían ruidos similares a los que, en consecuencia, se atribuyó el mismo poder de atracción: «turning backwards and forwards alternately, the iynx's wheel describes a double spiral; or even better, two spirals standing on the same axis (the iynx's cord) and with a common vertex, cyclically alternating their sense of rotation ${ }^{277}$.

El instrumento referido por Damascio opera tanto por su movimiento circular (el

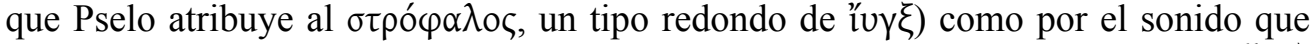

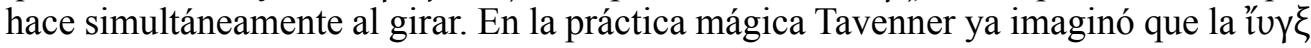
habría de moverse en un sentido para atraer a la persona deseada y en el contrario para alejarla $^{278}$, cual «rueda que gira atando y desatando los hilos del amor» ${ }^{279}$. Sinesio, ya

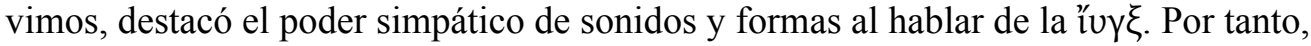

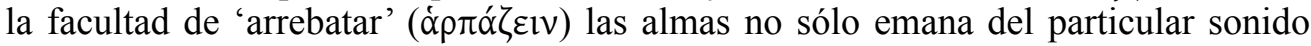
del aparato sino también de su forma y movimiento, que son de hecho iguales a los del vehículo anímico: según Jámblico, el vehículo del alma es esférico y se mueve en círculos ( si bien sigue una trayectoria recta al descender o ascender por las esferas planetarias $)^{280}$. Por ello Pselo expresó la conveniencia de que los teúrgos se rodearan

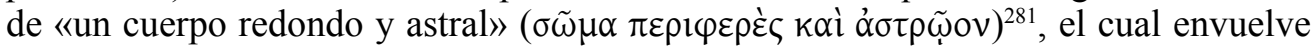
a su vez el vehículo anímico ${ }^{282}$. El alma que asciende hasta la realidad intelectiva, observa Damascio, entra en contacto místico con lo inteligible «en conformidad con

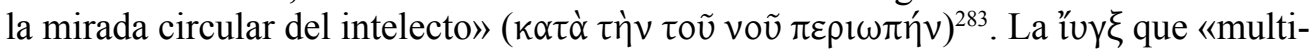
plica» los circuitos propios, examinado a la luz de Proclo $^{284}$, es un símbolo tanto de la procesión como de la reversión: por un lado, al girar desencadena una pluralidad de vueltas cual serie de números múltiplos; por el otro, al revertir su movimiento, la serie de vueltas se retrotrae desde el giro último hasta el punto de partida. En la concepción de Jámblico, según mostró Shaw, la circularidad también fue un rasgo de las prácticas adivinatorias y teúrgicas: en la manifestación de un dios, por ejemplo, la presencia divina desciende sobre el teúrgo y lo envuelve circularmente, produciendo un ruido

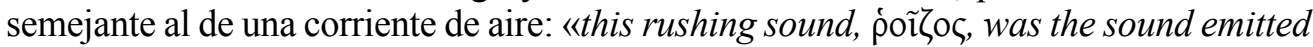

${ }^{275}$ Salvatore (1991: 18).

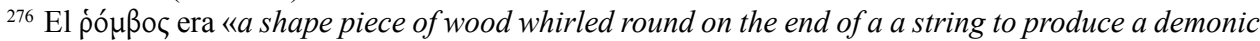
roaring noise» (West, 1992: 122). Porph., In Harm., p. 57, 18-19 Düring. Cf. Lang (1884), Mathews (1898), Schaeffner (1968: 131-133), Dundes (1976), Mathiesen (1999: 172-173) y Hagens (2005).

${ }^{277}$ Salvatore (1991: 21). Cf. Fletcher, Tarnopolsky \& Lai (2002: 1190, fig. 2, 1194).

${ }^{278}$ Tavenner (1933: 114, 127).

279 Perea Yébenes (2005: 221).

${ }^{280}$ Iambl., In Ti. III, fr. 49, 9-18 Dillon. Cf. Pl., Ti. 34b-36d Burnet; Plu., Mor. 1028a-b Hubert \& Drexler; D. L. III, 68 Markovich; Marsanes 25*, 21-29*, 1 Pearson; Procl., In Ti. II, p. 72, 13-18 Diehl; In Euc., p. 147, 15-18 Friedlein.

${ }^{281}$ Psel., Philos. minor. II, 15, p. 76, 7-9 O’Meara. Cf. Origenes, PG 11, 96a-b Migne; Simp., In Ph., p. 643, 27-28 Diels.

${ }^{282}$ Dam., Phil. hist. 153 Athanassiadi.

${ }^{283}$ Dam., In Prm. II, p. 46, 9-16 Westerink.

${ }^{284}$ Procl., In Euc., p. 150, 22-151, 3 Friedlein. 
by the stars in their celestial round, so the vehicle of the soul not only takes on the shape but also the sound of the gods» ${ }^{285}$.

Al examinar la definición de punto geométrico en Comentario a Euclides, Proclo dice que el centro y los polos de la esfera celeste simbolizan la naturaleza incognoscible y unitiva de las diosas ívүץeৎ; a ellas incumbe el mantenimiento del curso de las revoluciones de las esferas planetarias y del orden cósmico ${ }^{286}$. En apoyo de su exégesis recuerda que ya los pitagóricos vincularon a Zeus con el centro y a Rea con los polos ${ }^{287}$ - lo que implica una relación de las íuүyes tanto con el Demiurgo como con Hécate-, así como una observación platónica que extrae del mito de $\mathrm{Er}^{288}$. Para el neoplatónico, por otro lado, el círculo es la figura matemática más perfecta y divina, valoración que le da pie a citar uno de los Oráculos: «centro es (el punto) desde donde todas (las líneas) son iguales hasta la circunferencia» (fr. 167 ${ }^{289}$. Cabe inferir que el punto central representa la unidad y la permanencia; el punto que traza la circunferencia, la multiplicidad y el retorno; los polos, la relación habida entre ambos puntos, que son iguales y distintos al mismo tiempo.

Los Escolios a los Elementos de Euclides, aunque parafrasean a Proclo, recogen una interpretación un tanto diferente y atribuida esta vez a «los extranjeros»: el centro y los polos tienen potencias iuyүıkoí pero también 'guardianas ${ }^{290}$. Parece ser una exégesis más antigua de los Oráculos que remonta a sus autores mismos, o a sus primeros intérpretes, oriundos probablemente de Siria. Pselo, en efecto, da noticia de unos dioses 'guardianes' ( den pues con los Conectores. Damascio atribuye a estos últimos la acción de 'guardar' ( las cimas, después de agregar el vigor propio de su fuerza en los conectores $\rangle^{292}$; en teoría las 'cimas' que los Conectores custodian son las ǐvyүec. Proclo da testimonio de unas entidades que, «según el Oráculo, "son guardianes de las obras del Padre"»"293: Kroll entendió que se trata de las î́үүєৎ, pero la perspectiva neoplatónica señala a los Conectores. Al decir de Pselo, la función de guardar de los Indoblegables les vie-

${ }^{285}$ Shaw (2005: 154; cf. 147-148, 150, 155-156, 158). Iambl., Myst. III, 2, 103, 14-104, 4; 6, 113 , 8-14; 11, 126, 11-14 Places. Gigli Piccardi (1986: 273-274) destaca la imagen sonora que expresa ṕoı $\tilde{c} \omega$ (Orac. Chald. 37).

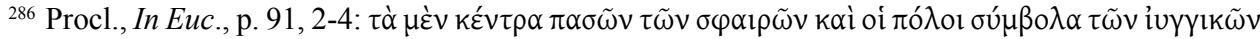

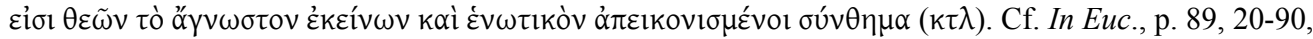
6 Friedlein; In R. II, p. 213, 1-2 Kroll.

${ }^{287}$ Procl., In Euc., p. 90, 14-20. Cf. Sch. Euc., Def. I, 1, p. 77, 9-12 Heiberg \& Stamatis; Arist., Cael. 293b Moraux y fr. 204 Rose; Simp., In Cael. II, 13, p. 511, 24-512, 20 Heiberg.

${ }^{288}$ Procl., In Euc., p. 90, 6-11; P1., R. 616c, 3-6 (cf. Ti. 40c; Cra. 404c-e).

${ }^{289}$ Procl., In Euc., p. 155, 5 (cf. p. 146, 18-156, 5). Cf. Pl., Ti. 33b-34b y Ep. 7, 342a-344b; Iambl., In Ti. III, fr. 49, 30-35 y 51-54.

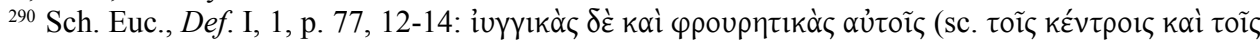

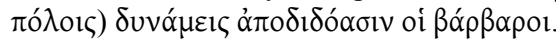

${ }^{291}$ Psel., Theol. 51, 88-90 Gautier.

${ }^{292}$ Dam., In Prm. II, p. 98, 3-4 Westerink.

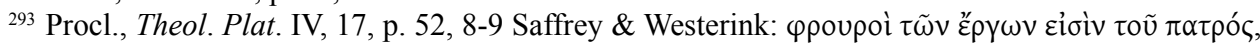

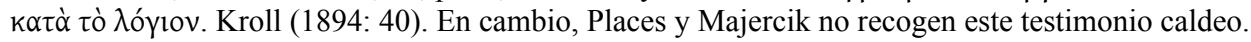


ne dada de los Conectores ${ }^{294}$. La función 'guardiana' ( $\left.\varphi \rho o u \rho \eta \tau \iota k n ́\right)$, que consiste en conservar un determinado orden cosmológico en su justa medida ${ }^{295}$, se encomienda a entidades intermedias: entre los inteligibles-intelectivos, a los Conectores, y entre los intelectivos, a los Indoblegables; asimismo, pareciera que el Abismo paterno, desde su posición central, protege a su vez el Uno-Bien o Principio paterno.

En el ritual mitraico, cuenta el filósofo Celso, una figura representaba los dos movimientos de rotación del cielo, el de las estrellas fijas y el de los astros errantes, mientras que otra, una escalera con siete peldaños y puertas y una octava puerta encima, simbolizaba el descenso y el ascenso del alma por las esferas celestes ${ }^{296}$. El doble movimiento exterior e interior que Damascio atribuye al aparato $\iota_{u} y \xi$, según propongo, podría representar lo que el $\sigma u ́ \mu \beta o \lambda o v$ mitraico, vinculado por Celso a planteamientos de la República y el Timeo. Según Platón, el universo realiza dos movimientos: la esfera exterior de las fijas, arrastrando consigo las esferas planetarias, gira en un sentido

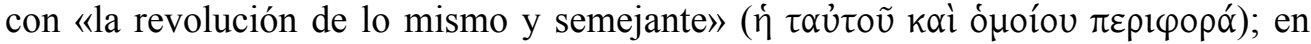
cambio, los siete círculos interiores (Saturno, Júpiter, Marte, Mercurio, Venus, Sol y Luna), a la vez que participan del movimiento del todo, giran en el sentido contrario

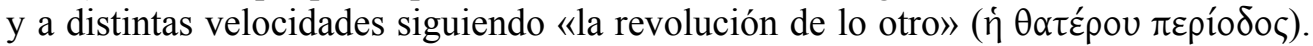
Las tres hijas de Necesidad son las encargadas de mover el universo: Cloto da vueltas al círculo exterior con la mano derecha; Átropo mueve los interiores con la izquierda; y Láquesis hace girar alternativamente uno y otros en direcciones opuestas, con sendas manos $^{297}$. Platón, asimismo, asocia la actividad cognitiva del alma con el movimiento circular del universo: al contemplar semejanzas el alma se mueve con lo idéntico, mientras que al percibir diferencias gira con el movimiento de lo diverso ${ }^{298}$.

Si los planetas están animados por dos movimientos, uno alrededor de la Tierra en una gran órbita circular llamada deferente, y otro alrededor de un punto móvil sobre el deferente mismo que traza un círculo menor llamado epiciclo ${ }^{299}$, cabe plantear que el instrumento ${ }^{\prime} u \gamma \xi \xi$ podría imitar este doble movimiento: su rotación externa reproduciría el movimiento de lo mismo (o sea, tanto del deferente como del epiciclo en su fase directa), mientras que la rotación interna imitaría el movimiento de lo otro (esto es, del epiciclo en su fase de retrogradación, contraria al deferente). A la doctrina pitagórica ${ }^{300}$ según la cual los cuerpos celestes se mueven en órbitas perfectamente circu-

${ }^{294}$ Psel., Philos. minor. II, 40, p. 149, 27-29 O’Meara.

${ }^{295}$ Procl., Inst. 154 Dodds.

${ }^{296}$ Origenes, Cels. VI, 22, 5-9 Borret. Culianou (2002: 88-90) opina que los mitraícos no celebraron el ritual de la elevación del alma: el orden planetario implícito en las tutelae planetarias atestiguadas en los mitreos de Santa Prisca y Felicísimo (Mercurio, Venus, Marte, Júpiter, Luna, Sol, Saturno) no corresponde a ninguna ordenación conocida de los planetas en el universo.

${ }^{297}$ Pl., R. 616d-617d; Ti. 38c-40d. Knorr (1990: 316). Cf. Arist., Cael. 289b-290b Prantl; Cic., Resp. VI, 20-21 Powell; Plin., NH II, 3 (3), 6 y 22 (20), 84 Mayhoff; Theo. Sm., p. 138, 9-143, 6 Hiller; Cens. 13, p. 22, 22-24, 12 Hultsch; Iambl., In Ti. III, fr. 49, 30-35 y 51-54 Dillon; Chal., Comm. 37 y 95 Wrobel; Boeth., Mus. 1, 27, p. 219, 4-28 Friedlein. Cf. Dreyer (19532: 56-86).

${ }^{298}$ Pl., Ti. 37a-c, 44a-b, 90c-d Burnet. Knorr (1990: 314). Cf. Procl., In Ti. III, p. 132, 19-20 Diehl.

${ }^{299}$ Cf. Dreyer (1953²: 149-170); Gabriel (1989); Evans (1999: 337-342, 355-359); Kelley \& Milone (2011: 36-37).

${ }^{300}$ Gem. 1, 19-21, p. 10, 2-20 Manitius; Porph., VP 30-31, p. 33, 1-34, 5 Nauck. 
lares y uniformes Platón añade la idea también pitagórica, así como caldea, de la música de las esferas: en cada uno de los ocho círculos se sienta una Sirena que emite un tono musical, resultando de todos ellos una sucesión de sonidos perfecta $(\dot{\alpha} \rho \mu o v i ́ \alpha)^{301}$.

Nicómaco de Gerasa formuló una conexión entre los planetas y el heptacordo antiguo conforme a un criterio posicional que va, por referencia a la Tierra inmóvil y excluido el círculo de las fijas, de la esfera más lejana a la más cercana, así como de

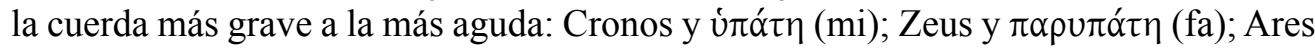

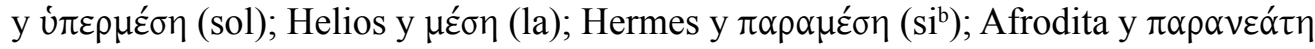

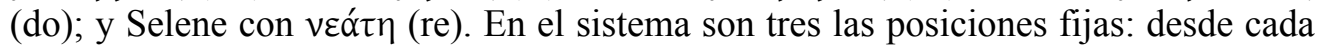
extremo, Cronos y Selene, hasta el centro, Helios, hay una misma distancia musical de una cuarta justa, e idéntica distribución de intervalos de dos tonos y medio que, por la adición de los dos tetracordios conjuntos, abarcan un registro de una séptima menor; o sea, involucra el sistema perfecto menor ${ }^{302}$. Esta teoría musical cobra una mayor significación dado que, al parecer, Nicómaco conoció las prácticas de los teúrgos de su tiempo:

Pues, en efecto, las notas musicales ( $\varphi \theta$ óyүol) de las siete esferas, cada una de las cuales produce de manera natural un solo sonido ( $\psi$ ó $\varphi \circ v$ ) de cierta cualidad, son los elementos a los que se dio el nombre de vocales ( $\tau \dot{\alpha} \sigma \tau o \imath \chi \varepsilon \tilde{\alpha} \alpha \tau \dot{\alpha} \varphi \omega v \eta ́ \varepsilon v \tau \alpha)$. Los sabios los califican de inefables en sí mismos y dado que todo se constituye a partir de ellos. Por esta razón, la nota musical tiene en nuestro mundo de aquí el mismo poder que la unidad en la aritmética, el punto en la geometría y letra en la gramática. Agregados a los sonidos materiales, cuales son las consonantes ( $\sigma u ́ \mu \varphi \omega v \alpha)$, tal como el alma se agrega al cuerpo y la escala musical a las cuerdas (la una produce seres vivos, la otra tonalidades y melodías), adquieren potencias que activan y perfeccionan las cosas relativas a los dioses. Por lo tanto, cuando los teúrgos ${ }^{303}$ rinden culto a una entidad tal con sonidos sibilantes y chasquidos ${ }^{304}$, con modulaciones de voz $^{305}$ inarticuladas y carentes de con-

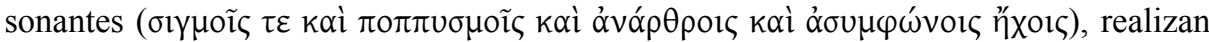
invocaciones por un medio simbólico ${ }^{306}$.

${ }^{301}$ P1., R. 617b-c Burnet. Cf. Arist., Cael. 290b-291a Prantl; Cic., Resp. VI, 22-23 Powell; Macr., Comm. II, 1 Willis; Procl., In R. II, p. 236, 16-239, 14 Kroll.

${ }^{302}$ Nicom., Harm. 3, p. 241, 1-242, 11; Exc. 3, p. 271, 16-273, 7 Janus. Cf. Mathiesen (1999: 396397) y Garrido Domené (2010: 166-179, 195).

${ }^{303}$ La lectio $\theta \varepsilon o u p y o i ́$, preferible para C.-É. Ruelle (Nicomaque de Gérase: Manuel d'harmonique, Paris, 1881: 50, n. 4), es la corrección de T. Gale (Rhetores selecti, Oxonii, 1676: 235) a la lectura $\theta \varepsilon p ı v o i ́$ dada por I. Meursius (Aristoxenus, Nicomachus, Alypius, Lugduni Batavorum, 1616: 89). M. Meibomius (Antiquae musicae auctores septem, Amstelodami, 1652: vol. I, col. 37a, 59b) corrigió Өrpıvoí

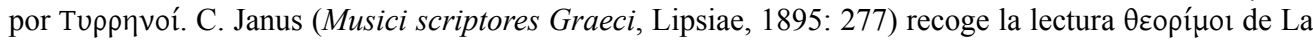
Croze, una voz copta (cf. M. V. La Croze, Lexicon Aegyptiaco-Latinum, Oxonii, 1775: 22).

${ }^{304}$ Cf. X., Eq. 9, 10 Marchant; Dexipp., In cat., p. 11, 26-27 Busse; Iuu. 6, 584 Segura Ramos; Plin., NH XXVIII, 2 (5), 25 Mayhoff; Plu., Mor. 713b Frazier \& Sirinelli; PMag. IV, 561-562 Preisendanz \& Henrichs; Fr. Bob., Gramm. Lat. VII, p. 544, 18 Keil; Poll. I, 210 Bethe; Mart. VII, 18, 11 Lindsay.

${ }^{305}$ Sobre el término $\tilde{\eta} x o l$ vid. Thibaut (1901) y Jeannin \& Puyade (1913: 97-98).

${ }^{306}$ Nicom., Exc. 6, p. 276, 8-277, 9 Janus. Para el contexto vid. Mathiesen (1999: 406-411). 
Lewy, empero, juzgó que la mención de los teúrgos es anacrónica: le parece más creíble que haya sido Proclo quien, interviniendo en la transmisión del texto, los añadió por cuenta propia ${ }^{307}$. Sin embargo, no hay datos conclusivos que rebatan la conjetura de que el neopitagórico Nicómaco — nacido en una localidad jordana próxima a Siria - fue coetáneo de los primeros teúrgos ${ }^{308}$. Además, otras fuentes confirman el testimonio de que los teúrgos solían servirse «sonis certis quibusdam ac uocibus» ${ }^{309}$ para, como fue el caso, vivificar objetos inanimados. Coherentemente, y como era de esperar, el texto de autoridad que fundamentó la teúrgia otorga un papel igualmente relevante al mundo sonoro: «la cosmologie et la psychologie des Oracles Chaldaïques ne sont même pas concevables en dehors d'une 'musicologie' fondamentale qui fait de la musique l'essence même de la réalité antique de l'univers» ${ }^{310}$, concluía Moutsopoulos.

En las correspondencias nicomaqueas de notas musicales, posiciones planetarias y sonidos vocálicos, basadas en la analogía del número siete, está implícito el llamado «canto de las siete vocales» ${ }^{311}$. Poirée propuso la tesis según la cual en los Papiros griegos de magia las vocales del alfabeto sirvieron para escribir música: en ocasiones las secuencias vocálicas y sus variantes, tenidas comúnmente por glosolalia o voces mágicas sin significado, anotan en realidad motivos y frases musicales ${ }^{312}$; este método de anotación es un precedente de la solmización. Las fuentes de la teúrgia, ciertamente, no registran fórmulas vocálicas como las que hay a su vez en algunos textos gnósticos (El evangelio de los egipcios, Sobre la ogdóada y la enéada ${ }^{313}$, por ejemplo); con todo, en los Oráculos sí se hallan los elementos que podrían fundamentar esta forma de canto.

Filón de Alejandría y Plutarco de Queronea atribuyen a «los caldeos» no sólo las leyes que rigen las relaciones musicales y la música celeste, sino también una serie de correlaciones similar a la de Nicómaco y que incluye asimismo las vocales ${ }^{314}$. Aunque

${ }^{307}$ Lewy (1978: 250, n. 83).

${ }^{308}$ Garrido Domené (2010: 76-82) resume los intríngulis en torno a la datación de Nicómaco.

${ }^{309}$ Aug., CD X, 11, p. 466, 28 Hoffmann. Cf. Iambl., Myst. III, 5, 111, 17-112, 9; 9, 117, 13-120, 14

Places; Procl., In Cra. 71, p. 31, 24-28 Pasquali; Marin., Procl. 28, 10-12 Saffrey \& Segonds.

${ }^{310}$ Moutsopoulos (1990: 293).

311 Arist., Metaph. 1093a, 13-15 Jaeger; Ach. Tat., Intr. Arat. 16-17 Maass; Sch. D.T., p. 197, 31-198, 6 Hilgard; Seru., Aen. VI, 247 Thilo; Eus., PE V, 14, 1 (Porph., Phil. orac., p. 138 Wolff); XI, 6, 37 Mras; Iren. Lug., Haer. I, 8, 8 (14, 7), p. 142 Harvey; Horap. II, 29 Sbordone; Theol. Ar. 7, p. 54, 11-56, 7 Falco \& Klein; Varro Atacin., fr. 11 Blänsford; Mar. Vict., Gramm. Lat. VI, p. 60, 5-14 Keil; Lyd., Mens. II, 3 Wuensch; Nicol. Myrepsus XXI, 1 (R. Heim, Incantamenta magica Graeca Latina, Lipsiae, 1892: 540, n. $\left.{ }^{\circ} 233\right)$; vid. nuestra n. 314. Cf. Ruelle (1889, 1901), Bailly (1907), Leclercq (1924), Wellesz (1980²: 65-77), Miller (1986) y Touliatos (1989).

312 Poirée (1901) transcribe al pentagrama las secuencias vocálicas: PMag. IV, 465-466, 953-955, 1004-1005, 1011-1012, 1040-1041, 1183, 1207; XII, 189, 336; XIII, 78-79, 207-208, 557-558, 625-626, 631-632, 820-821, 849-850, 852-854, 857-858, 879-881, 894-895, 905-911; así como la registrada por U. F. Kopp, Palaeographia critica III, Mannhemii, 1829: 303, §255.

${ }^{313}$ NH III, 2: 44, 3-9; 66, 12-22; IV, 2: 54, 3-13; 78, 17-19 Böhlig \& Wisse; VI, 6: 56, 17-22; 61, 10-15 Dirkse, Brashler \& Parrot.

${ }^{314}$ Ph., Migr. Abr. 178, p. 303, 5-10 Wendland; Abr. 69 (15), p. 16, 21-17, 7 Cohn; Plu., Mor. 386a-b; 1028e-f Hubert \& Drexler (cf. Farmer, 19875: 279-280). Según Demetr., Eloc. 2, 71 Radermacher los 
«los caldeos» mencionados no son los Caldeos responsables de los Oráculos, cabe sospechar que entre ellos debió de haber algún parentesco (cuyo alcance, empero, las fuentes antiguas no permiten esclarecer y acotar al día de hoy): parece lógico y natural que unos y otros hayan compartido los principios de una cosmovisión caldaica. Otra

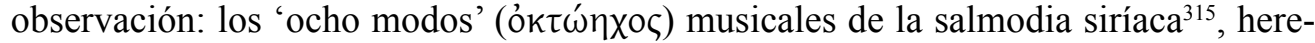
dados y renovados por la liturgia bizantina, ejemplifican el alto desarrollo que alcanzó la música sacra en la región de Siria, la presunta patria de los Oráculos $^{316}$.

Los Oráculos caldeos ofrecen esta cosmovisión: el cielo fue creado «por medio de un (único) trazo en forma curva» (fr. 63), que se cierra en la figura de un círculo; el cielo es mímesis del Intelecto (fr. 69), a los que la tradición platónica asigna forma circular; el Sol ocupa el lugar intermedio y equidistante del sistema celeste, cuarto entre los planetas y quinto entre las estrellas y la Tierra fijas (fr. 58, 65, 111) - como ocurre en el esquema cósmico-musical de Nicómaco-; el modelo de universo es geocéntrico (fr. 70), lo que permite, partiendo de la Tierra, el ascenso gradual del alma en su

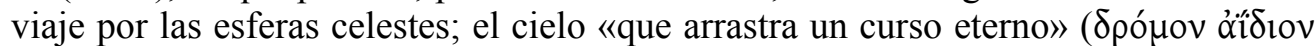

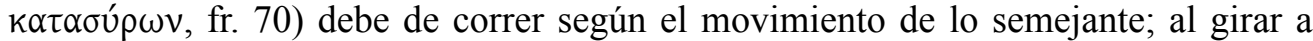
gran velocidad por acción de la 'necesidad' (å $\alpha$ ó $\gamma \kappa \eta)$, la Luna produce un «zumbido»

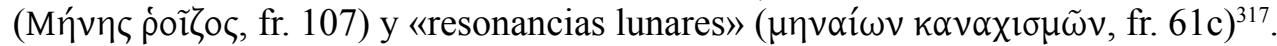

Los teúrgos, según propongo, quienes podrían oír la música celeste como hacía Pitágoras $^{318}$, habrían asignado a la Luna y a los demás astros distintas alturas musicales en un sistema tonal definido por el orden planetario. Ellos, además de imitar el doble movimiento de los cielos, pudieron reproducir la música de las esferas de dos maneras: a) mediante el canto planetario de las vocales: Ruelle sugería esta hipótesis cuando, traduciendo a Nicómaco, interpreta que los teúrgos emitían «sons sans consonnes» ${ }^{319}$

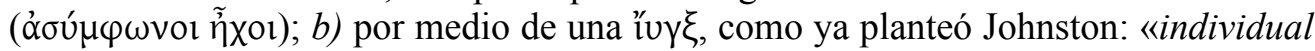
iunx-wheels were intended to affect — and thus control - individual celestial spheres by imitating not only the sphere's motion but also the specific tones that they contributed to the music to the spheres» ${ }^{320}$; con todo, sigue siendo una incógnita qué instrumento es aquél «whose many sounds — presumía Detienne - correspond to the move-

sacerdotes egipcios acompañaban sus himnos con el canto de las vocales. El sistema de correspondencias de Nicómaco sería (cf. Touliatos, 1989: 232, n. 9):

\begin{tabular}{|c|c|c|c|c|c|c|}
\hline $\begin{array}{l}\text { Luna } \\
\text { veá } \tau \eta\end{array}$ & $\begin{array}{c}\text { Venus } \\
\pi \alpha \rho \alpha v \varepsilon \alpha ́ \alpha \eta\end{array}$ & $\begin{array}{l}\text { Mercurio } \\
\pi \alpha \rho \alpha \mu \varepsilon \dot{\sigma} \emptyset\end{array}$ & 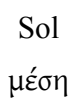 & 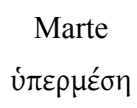 & $\begin{array}{l}\text { Júpiter } \\
\pi \alpha \rho u \pi \alpha ́ \tau \eta \eta\end{array}$ & 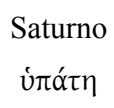 \\
\hline re & do & $\mathrm{si}^{\mathrm{b}}$ & la & sol & $\mathrm{fa}$ & $\mathrm{mi}$ \\
\hline A & E & $\mathrm{H}$ & I & $\mathrm{O}$ & Y & $\Omega$ \\
\hline
\end{tabular}

${ }^{315}$ Cf. Jeannin \& Puyade (1913). Farmer $\left(1987^{5}: 280\right)$ juzga que esta teoría musical debe de remontar a los templos de Mesopotamia.

${ }^{316}$ Saffrey (1981: 225); Athanassiadi (1999: 153-156); Fernández Fernández (2011: 92-96, 113-122).

${ }^{317}$ Cf. Nicom., Harm. 3, p. 241, 3-11 Janus.

${ }^{318}$ Porph., VP 30, p. 33, 4-7 Nauck (Vorsokr. 31 [21], B 129, p. 363, 11-14 Diels \& Kranz). En cambio, Aristóteles (Cael. 290b Moraux) negó que la música celeste sea audible para el hombre.

${ }^{319}$ Ruelle, op. cit. n. 303: 50.

${ }^{320}$ Johnston (1990: 101). Cf. Majercik (1989: 10). 
ments it performs » ${ }^{321}$; según registran léxicos bizantinos de los siglos XI-XII la ťy $\xi$ fue un tipo de 'siringa' ( $\sigma \tilde{\mathrm{v} \rho l \gamma} \xi)^{322}$; acaso fueron dos los instrumentos usados, homónimos: uno propiamente musical, otro rotatorio y aerófono. En tal contexto, ¿habrán podido realizar los teúrgos una ceremonia de escenificación similar a la de las siete 'circunvalaciones' (tawāf) rituales en torno a la Ka'ba? ${ }^{323}$

Falta dilucidar con qué objeto se habría reproducido la música celeste. El escolio a la Eneida de Virgilio que vincula las siete cuerdas de la lira con las zonas planetarias y advierte que el alma no puede elevarse «sin la cítara» ${ }^{324}$, confiere verosimilitud a la siguiente conjetura: los teúrgos, quienes aspiraban a liberarse de la condición natural y

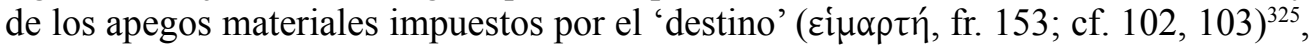
se habrían servido de melodías para impulsar el alma en su ascenso por «los carriles de fuego» (fr. 36) planetarios y elevarla hasta el 'fuego' (fr. 3, 5, 6, 10) que emana del Padre; «el ascenso al fuego inteligible», dictamina Jámblico, era «la culminación (...) de toda actividad teúrgica ${ }^{326}$.

Culianu subrayó el simbolismo que tuvieron las alas en el período del platonismo medio por influencia del motivo platónico de las alas del alma: para los paganos «les ailes représentent la pensée ou le désir amoureaux qui éleve l'âme à la contemplation des espèces idéales»; para los cristianos, «la grâce du Saint-Esprit» ${ }^{327}$. La observación

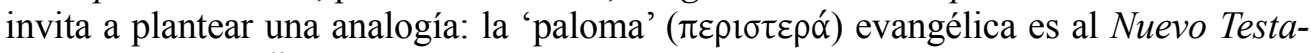

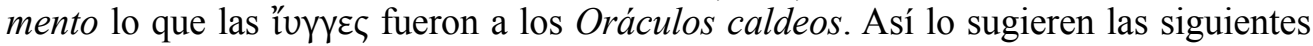
similitudes: a) la paloma, epifanía del Espíritu de Dios, media entre el Padre y Jesús a la hora del bautismo ${ }^{328}$ (Dixon argumenta que el motivo del descenso del Espíritu como paloma, inexistente en el Antiguo testamento, proviene de la épica griega de tradición homérica en que los dioses adoptan formas de ave en su encuentro con los mortales ${ }^{329}$ );

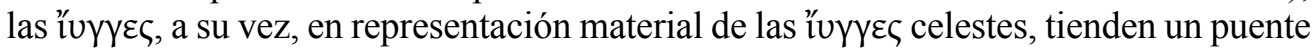
entre el fuego del Padre y el teúrgo; b) según una tradición velada el Espíritu encarnó

${ }^{321}$ Detienne (1994: 84).

322 West (1992: 113) [cf. n. 28].

${ }^{323}$ Pallejá de Bustinza (2005: 22-23, 25): «Las rondas rituales se efectúan empezando por el ángulo de la Piedra Negra (...). Se realizan las siete vueltas, en sentido contrario a las manecillas del reloj (...). El trayecto de las tres primeras vueltas se realiza con un tipo de paso rápido ( $\mathrm{ramal}$ ) y las restantes a paso normal, siempre guardando una distancia respecto al edificio de la $\mathrm{Ka}$ 'ba (...). Al terminar las rotaciones, el fiel se aproxima (...). Las circunvalaciones rituales se realizan dejando el edificio a la izquierda, siendo la derecha aquella que corresponde a la mirada hacia el 'exterior', mientras que 'la diestra' de la Ka'ba se encuentra en el lado 'interior'». Cf. Glassé, s.v. «Ṭawāf» (20083: 518).

${ }^{324}$ PEG II.1, Orph., fr. 417 Bernabé (Parisinus Lat. 7930, Sch. Verg., Aen. VI, 119): Si potuit Manes] Dicunt tamen quidam liram Orphei cum VII cordis fuisse, et celum habet VII zonas, unde teologia assignatur. Varro autem dicit librum Orfei de vocanda anima Liram nominari, et negantur animae sine cithara posse ascendere. Cf. Nock (1927). Sobre la lira como símbolo del universo y su papel en la escatología astral vid. Molina Moreno (2003: 412-440).

${ }^{325}$ Lewy (1978: 212, n. 143).

${ }^{326}$ Iambl., Myst. III, 31, 179, 9-12 Places. Cf. Procl., Phil. Chal. 2, p. 207, 23-208, 5 Places.

${ }^{327}$ Culianu (1981: 65). Cf. Pl., Phdr. 249a-c. Para Durand (2004: 131-150) la escalera, la montaña, el ala, el pájaro y el ángel son símbolos 'ascensionales' que expresan verticalidad y elevación.

${ }^{328}$ Eu. Mat. 3, 16; Eu. Marc. 1, 10; Eu. Luc. 3, 22; Eu. Io. 1, 32 Robinson \& Pierpont.

${ }^{329}$ Dixon (2009: 760, 769, 779). 
en su origen el aspecto femenino de Dios y fue considerado 'madre' de Jesús ${ }^{330}$; las

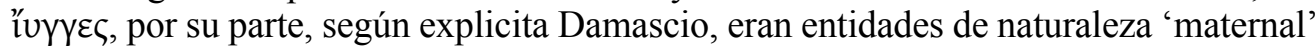
(Durand asigna al arquetipo 'la mujer' una función esencialmente mediadora ${ }^{331}$ ); $c$ ) «un

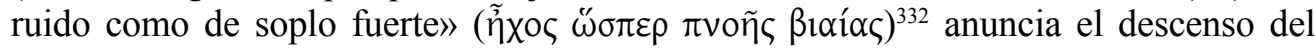
Espíritu desde el cielo; las "uүүץৎ, por su parte, descienden por las esferas celestes «en

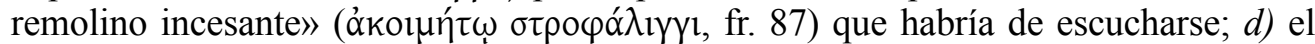
Espíritu Santo se materializa en «lenguas como de fuego» $(\gamma \lambda \tilde{\omega} \sigma \sigma \alpha \iota \omega \dot{\omega} \sigma \varepsilon \dot{\imath} \pi u \rho o ́ \varsigma){ }^{333}$; las

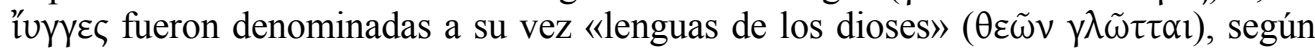
se atestigua en Filóstrato (aunque no en los Oráculos conservados). En los Oráculos caldeos, así pues, también pudo perdurar el sentido primario de "̌jy como ave.

Al parecer, el torcecuello no habría sido el único pájaro aludido en los Oráculos. Proclo afirma que los caldeos, en su afán por imitar el lenguaje más puro de los dioses, llamaron $\chi \propto \chi$ kí ('broncínea', fr. 210: en alusión, según el neoplatónico, a un timbre agudo y penetrante; según un escolio, al color del plumaje) al ave que el común de los

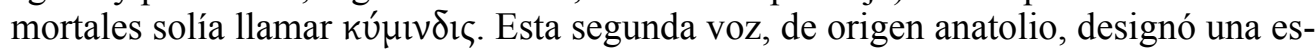
pecie de mochuelo endémica de Jonia ${ }^{334}$; puede descartarse la hipótesis de que ambos términos hayan sido sinónimos de $\imath^{\prime \prime} \gamma \xi$. El testimonio de Proclo remonta a Homero, por mediación aparente de Platón ${ }^{335}$. El precedente homérico hizo a Majercik dudar de la autenticidad del fr. 210: sin embargo, los Oráculos atestiguan homerismos y fórmulas homéricas. Majercik, con todo, llegó a admitir la posibilidad, ya ideada por Lewy, de que los caldeos hubieran usado pájaros de bronce para, haciéndolos resonar, ahuyentar con la estridencia a los malos espíritus ${ }^{336}$; suposición que, empero, no está corroborada por las fuentes teúrgicas.

La teúrgia, según vimos, atribuyó a los sonidos 'inarticulados' (ő́v $\alpha \rho \theta \rho o \imath)$ un simbolismo tal que con ellos se podía invocar a los dioses. El 'disco' ( $\sigma \tau \rho o ́ \varphi \alpha \lambda o \varsigma)$ de Hécate, al hacerlo girar, se acompañaba de emisiones de voz ininteligibles y de voces

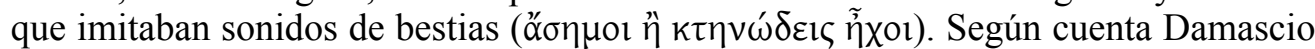
en su Historia de la filosofia, en la Academia de Atenas del siglo v los filósofos Isidoro y Proclo celebraban extravagantes ceremonias caldaicas en las que no sólo aleteaban los brazos ${ }^{337}$, simulando emprender el vuelo, sino también imitaban gritos de pájaros

${ }^{330}$ Origenes, In Eu. Io. II, 12, 87 Preuschen; Hieron., In Mi. 7, 5-7, p. 513 Adriaen; Eu. Philip. 55, 23-35 Layton (trad. Isenberg). Cf. DeConick (2011: 1-38).

${ }^{331}$ Durand (1971: 41-42, 75, 86; 2004: 137-138).

${ }_{332}$ Act. 2, 2 Robinson \& Pierpont.

333 Act. $2,3$.

${ }^{334}$ Janko (1994: 196-197); Arnott, s.v. «Kymindis, Kybindis» (2007: 185-186).

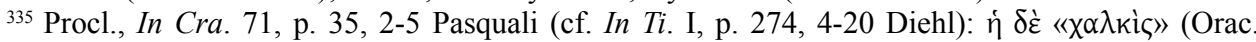

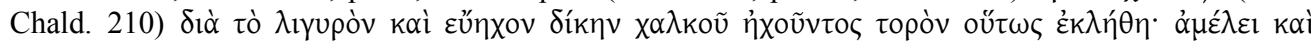

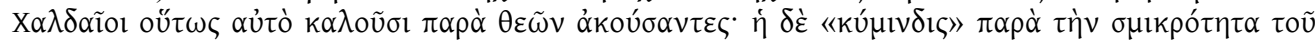
ópvéov. Cf. Il. XIV, 290-291 Monro \& Allen; Pl., Cra. 392a, 5 Burnet; Herm., In Phdr. III, 37, 252b,

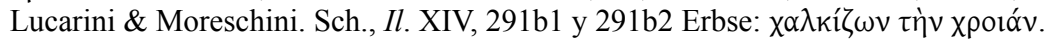

${ }^{336}$ Lewy (1978: 291, n. 124); Majercik (1989: 30, 216), quien remite al testimonio de C. Bailey, The religion of ancient Rome, Chicago, 1907: 54. Cf. Plu., Mor. 944b Cherniss.

${ }^{337}$ Cf. Ps. Aug., Quaest. VT et NT 114, 11, p. 308, 20-21 Souter; CIL VI, 751b, 9: HIEROCORACiCA. Durand (2004: 136-137): «La herramienta ascensional por excelencia es realmente el ala. (...) Todas las imágenes ornitológicas remiten al deseo dinámico de elevación, de sublimación». 
pequeños (como el $\sigma \tau \rho o v \theta$ ó, Passer dosmesticus, 'gorrión común') ${ }^{338}$ y de aves domésticas, o de corral. En tal contexto es donde probablemente hay que explicar el uso de aves: una de ellas pudo ser el torcecuello, que también es chico y domesticable.

A modo de resumen recojo el que, según las fuentes y las interpretaciones de los investigadores, parece ser el campo semántico de la voz lúv $\xi^{339}$. Incluyo con cautela acepciones dudosas, incontrastables e hipotéticas:

1. Pájaro,

a) torcecuello euroasiático, Jynx torquilla (alolemas: ǐvv

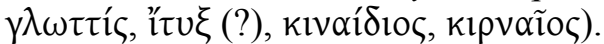

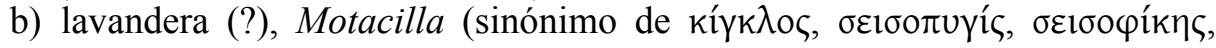

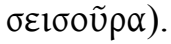

c) animal fabuloso alado (?).

2. Instrumento,

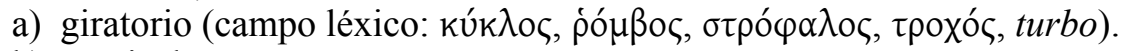

b) musical,

I. aerófono,

1. rotatorio libre (campo léxico: $\rho$ ó $\mu \beta o \varsigma, ~ \kappa \tilde{\omega} \vee o \varsigma)$.

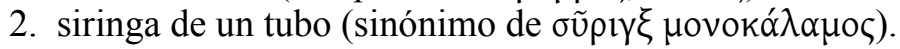

3. flauta travesera (?) (sinónimo de $\pi \lambda \lambda^{\prime} \gamma$ lo $\alpha$ $u ̉$ ó $)$ ).

II. cordófono (?),

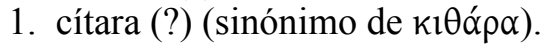

c) aro con radios, figuras de pájaros en derredor y motivos geométricos (?).

d) señuelo o trampa para aves con forma de rueda (?).

3. Poder para atraer irresistiblemente,

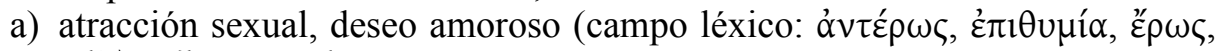

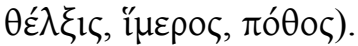

b) atracción no-sexual,

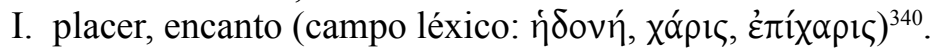

II. afecto (campo léxico: $\varphi \imath \lambda i ́ \alpha)$.

III. nostalgia, añoranza.

4. Fórmula mágica,

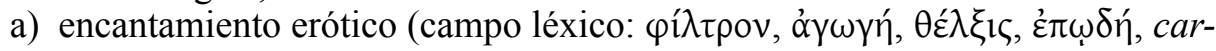
mina).

b) encantamiento no-erótico, ensalmo.

5. Hechizo amoroso (campo léxico: $\varphi$ í $\tau$ $\rho o v$, maleficium).

6. Capacidad persuasiva de un texto, oral o escrito (campo léxico: $\pi \varepsilon \imath \theta \omega ́$ ).

7. Realidades demónicas de la teología caldaico-neoplatónica,

${ }^{338}$ Dam., Phil. hist. 59 Athanassiadi. Cf. Arnott, s.v. «Strouthos (1A)», «Strouthos katoikas» (2007: 330-333, 336).

${ }^{339}$ Martínez (2003a: 111-112): «Corrientemente se distingue el campo léxico y el campo semántico; el primero se interesa por todas las palabras que designan un mismo sector de la realidad, mientras que el segundo se dedica a un solo término que puede tener muy diversas utilizaciones (Pottier, [B. (dir.), El lenguaje (diccionario de lingüística), Bilbao,] 1985, s.v. campo léxico)».

${ }^{340}$ En este punto resulta ilustrativo el trabajo de García Parejo (1997). 
a) Pensamientos del dios Padre.

b) Entidades superiores del orden inteligible-intelectivo.

8. Personaje mitológico,

a) Hija de Eco, o Persuasión, y de Pan.

b) Menta.

c) Piéride.

\section{BiBLIOGRAFÍA}

Aberbach, M. et al. (2007²), «Ezekiel», Encycl. Jud. VI: 635-646.

AdRADOs, F. R. et al. (1977), Introducción a la lexicografía griega. Madrid.

ArnotT, W. G. (2007), Birds in the ancient world from A to Z. Abingdon, Oxfordshired.

Athanassiadi, P. (1999), «The Chaldaean Oracles: theology and theurgy», en P. Athanassiadi \& M. Frede (eds.), Pagan monotheism in Late Antiquity. Oxford: 149-183.

BAILly, E. (1907), «Note sur la reconstitution d'une invocation aux dieux planétaires, chantée sur les sept voyelles dans les temples de l'antique Égypte, avec accompagnement de harpes et flûtes-doubles», en Transactions of the third annual congress of the Federation of European Sections of the Theosophical Society held in Paris... 1906. London: 335-341.

BeEKes, R. (2009-2010), Etymological dictionary of Greek. Leiden-Boston MA.

BirdLife InTERNATIONAL (2012), «Jynx torquilla», International Union for Conservation of Nature: IUCN red list of threatened species. Version 2014.3.

http://www.iucnredlist.org/details/22680683/0

— (2013), «Jynx torquilla». http://www.birdlife.org.

Boccaccini, G. (1998), "The Essenes in ancient historiography», Beyond the Essene hypothesis: the parting of the ways between Qumran and Enochic Judaism. Grand Rapids MI: 21-49.

BöHr, E. (1997), «A rare bird on Greek vases: the wryneck», en J. H. Oakley, W. D. E. Coulson \& O. Palagia (eds.), Athenian potters and painters. Oxford: 109-123.

Borgeaud, P. (1988), The cult of Pan in ancient Greece, transl. by K. Adass \& J. Redfield. Chicago IL (original: Recherches sur le dieu Pan. Rome, 1979).

Burton, M. (ed.), (2002³), «Wryneck», International wildlife encyclopedia XXI. New York: 2996-2997.

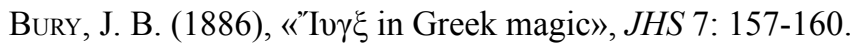

Bynon, J. (1987), «North African bird lore: new light on old problems», Folklore 98(2): 152-174.

Cansdale, L. (1997), «The Essenes», Qumran and the Essenes: a re-evaluation of the evidence. Tübingen: 19-33.

CAPPONI, F. (1981), «Avifauna e magia», Latomus 40(2): 292-304.

CARmona VÁzQuez, A. (2000-2002), «Estudios de campos semánticos en griego: presupuestos lingüísticos», ExcPhilol 10-12: 47-62.

Chantraine, P. (1968-1980), Dictionnaire étymologique de la langue grecque. Paris.

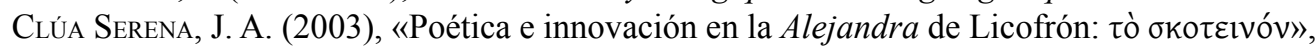
Anuario de estudios filológicos 26: 43-56. 
Combarieu, J. (ed.), (1901), Congrès international d'histoire de la musique tenu à Paris à la bibliothèque de l'Opéra du 23 au 29 juillet 1900 (VIIIe section du congrès d'histoire comparée): documents, mémoires et vúux. Solesmes.

Cook, A. B. (1914), Zeus: a study in ancient religion. Cambridge.

Cortés, J. A. \& Domínguez, M. A. (1997), «Distribución y caracterización del hábitat del torcecuello (Jynx torquilla) en la provincia de Málaga: datos preliminares», en J. Manrique (coord.), Actas de las XII jornadas ornitológicas españolas: Almerimar (El Ejido-Almería), 15 a 19 de septiembre, 1994. Almería: 39-45.

Culianu, I. P. (1981), «Le vol magique dans l'Antiquité tardive (quelques considérations)», RHR 198(1): 57-66.

- (1994), «La ascensión del alma en los misterios de las Antigüedad tardía», Experiencias del éxtasis, pref. de M. Eliade, trad. de I. Arias Pérez. Barcelona: 81-94.

DeConick, A. D. (2011), Holy misogyny: why the sex and gender conflicts in the early Church still matter. New York.

Detienne, M. (1994), «The misfortunes of Mint», The gardens of Adonis: spices in Greek mythology, transl. by J. Lloyd, introd. by J.-P. Vernant. Princeton NJ: $72-98$ (original: Les jardins d'Adonis: la mythologie des aromates en Grèce. Paris, 1972).

De Zorzi, N. (2009), «Bird divination in Mesopotamia: new evidence from BM 108874», Kaskal 6: 85-135.

Dillon, J. (2002), «The Essenes in Greek sources: some reflections», en J. R. Bartlett (ed.), Jews in the Hellenistic and Roman cities. London: 117-128.

Dixon, C. (1888), «The wryneck (Iynx torquilla)», Our rarer birds: being studies in ornithology \& oology. London: 129-134.

Dixon, E. P. (2009), «Descending Spirit and descending gods: a "Greek" interpretation of the Spirit's “descent as a dove" in Mark 1:10», JBL 128(4): 759-780.

Doughty, C. M. (1888), Travels in Arabia deserta. Cambridge.

Douglas, N. (1927), Birds and beast of the Greek Anthology. Florence.

Dreyer, J. L. E. $\left(1953^{2}\right)$, A history of astronomy from Thales to Kepler. New York.

DufFY, J. (1995), «Reaction of two Byzantines intelectuals to the theory and practice of magic: Michael Psellos and Michael Italikos», en H. Maguire (ed.), Byzantine magic. Washington DC: 83-97.

Dundes, A. (1976), «A psychoanalitic study of the bullroarer», Man 11(2): 220-238.

DuRAND, G. (2004), Las estructuras antropológicas del imaginario: introducción a la arquetipología general, trad. V. Golsdtein. México (original: Les structures anthropologiques de l'imaginaire: introduction à l'archétypologie générale. Paris, 1992 $\left.{ }^{11}\right)$.

- (1971) La imaginación simbólica, trad. M. Rojzman. Buenos Aires (original: L'imagination symbolique. Paris, 1993 ${ }^{3}$ ).

Elior, R. (1998), «The Merkavah tradition and the emergence of Jewish mysticism: from Temple to Merkavah, from Hekhal to Hekhalot, from priestly opposition to gazing upon the Merkavah», en A. Oppenheimer (ed.), Sino-Judaica: Jews and Christians in historical dialogue. Tel Aviv: 101-158.

Evans, J. (1998), The history and practice of ancient astronomy. Oxford-New York.

FARAONE, C. A. (1993), «The wheel, the whip and other implements of torture: erotic magic in Pindar Pythian 4.213-19», CJ 89(1): 1-19.

- (1999) Ancient Greek love magic. Cambridge MA. 
- (2006) «Priestess and courtesan: the ambivalence of female leadership in Aristophanes' Lysistrata», en C. A. Faraone \& L. K. McClure (eds.), Prostitutes and courtesans in the Ancient World. Wisconsin WI: 207-223.

FArmer, H. G. (19875), «La musica dell'antica Mesopotamia», en E. Wellesz (ed.), Musica antica e orientale, trad. di G. Tintori. Milano: 253-280 (original: «The music of ancient Mesopotamia», The New Oxford history of music. 1, Ancient and Oriental music. London, 1957: 228-254).

Fernández Delgado, J. A. (2006), «Diosas y/o brujas hechiceras míticas (y menos míticas) de Grecia», Mene 6: 93-108.

FERNÁNDEZ FERNÁNDEZ, Á. (2002), «Dos prácticas de encantamiento amoroso: el PGM IV (296404) y el Idilio II de Teócrito», en J. Peláez (ed.), El dios que hechiza y encanta: magia y astrología en el mundo clásico y helenístico. Córdoba: 91-102.

- (2011), La teúrgia de los Oráculos Caldeos: cuestiones de léxico y de contexto histórico, tesis doctoral dirigida por J. L. Calvo Martínez. Universidad de Granada. http://adrastea.ugr.es/record=b2070925.

Fletcher, N. H., TARnopolsky, A. Z. \& LAI, J. C. (2002), «Rotational aerophones», Journal of The Acoustical Society of America 111(3): 1189-1196.

Foufopoulos, J. \& Litinas, N. (2005), «Crows and ravens in the Mediterranean (the Nile Valley, Greece and Italy) as presented in the ancient and modern proverbial literature», BASP 42: 7-40.

Friedrich, P. (1997), «An avian and aphrodisian reading of Homer's Odyssey», American Anthropologist 99(2): 306-320.

Frisk, H. (1960-1972), Griechisches etymologisches Wörterbuch. Heidelberg.

FunARI, P. P. de A. (1995), «Apotropaic symbolism at Pompeii: a reading of the graffiti evidence», Revista de história 132: 9-17. http://www.revistas.usp.br/revhistoria/article/view/18750

Gabriel, M. (1989), «La théorie des épicycles I: des origines à Hipparque», Ciel et terre 105: $5-9$.

- (1989) «La théorie des épicycles II: l'œuvre de Ptolémée», Ciel et terre 105: 91-94.

García Parejo, I. (1997), El campo semántico «placer» en español, tesis doctoral dirigida por G. Salvador Caja. Universidad Complutense de Madrid. http://eprints.ucm.es/3875

Garrido Domené, F. (2010), Los teóricos menores de la música griega: Euclides, Nicómaco de Gerasa y Gaudencio: traducción y comentario, tesis doctoral dirigida por J. García López. Universidad de Murcia.

http://interclassica.um.es/investigacion/tesis/los_teoricos_menores_de_la_musica_griega_euclides nicomaco de gerasa y gaudencio traduccion y comentario/(ver) $/ 1$

Gigli Piccardi, D. (1986), «Sul fr. 37 degli Oracoli caldaici», Prometheus 12(3): 267-281.

Gilbert, A. S., (2001), «The native fauna of the ancient Near East», en B. J. Collins (ed.), $A$ history of the animal world in the ancient Near East. Leiden: 3-75.

Gilhus, I. S. (2006), Animals, gods, and humans: changing attitudes to animals in Greek, Roman and early Christian ideas. London.

GLAssé, C. (2008³), The new encyclopedia of Islam. Lanham MD.

GodDard, B. L. (2007), Animals and birds of the Bible. Lafayette IN.

GodwIn, J. (1993), The harmony of the spheres: a sourcebook of the Pythagorean tradition in music. Rochester VT. 
González Escudero, J. V., Gómez González, J. R. \& Muñoz Espejo, B. (2002), El torcecuello: determinación de la edad y el sexo, reproducción y fenología en el Noroeste peninsular ibérico. Gijón.

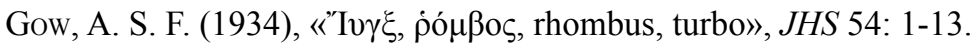

Graninger, D. (2011), Cult and koinon in Hellenistic Thessaly. Leiden.

Grimm, R. E. (1962), «Pindar and the beast», CPh 57(1): 1-9.

Hagens, B. (2005), «Timbre of the spheres: the bullroarer and the magic wheel», en Actes électroniques du colloque interdisciplinaire de musicologie (CIM05), Montréal (Québec) Canada, 2005. http://oicrm.org/wp-content/uploads/2012/03/HAGENS_B_CIM05.pdf

Hermoso Félix, M. J. (2011), El símbolo en el «De mysteriis» de Jámblico: la mediación entre el hombre y lo divino, tesis doctoral dirigida por T. Calvo Martínez. Universidad Complutense de Madrid. http://eprints.ucm.es/14087

JANKO, R. (1994), The Iliad: a commentary. 4, Books 13-16. Cambridge.

JeAnnin, J. \& Puyade, J. (1913), «L'octoëchos syrien», OC 3: 82-104, 277-298.

Jentoft-Nilsen, M. R. \& Trendall, A. D. (1991), Corpus vasorum antiquorum: United States of America, 27: The J. Paul Getty Museum, Malibu, 4. Malibu.

Johnston, S. I. (1990), «Hekate's top and the iynx-wheel», Hekate soteira: a study of Hekate's roles in the "Chaldaean Oracles» and related literature. Atlanta GA: 90-110.

- (1995) «The song of the iunx: magic and rhetoric in Pythian 4», TAPhS 125: 177-206.

Karagheorgis, V. (1989), «Two votive 'iynx-wheels' from Cyprus», en R. Étienne, M.-T. Le Dinahet \& M. Yon (eds.), Architecture et poésie dans le monde grec: hommage à Georges Roux. Lyon-Paris: 263-268.

Kaske, C. V. \& Clark, J. R., (ed. \& transl.), (1989), Marsilio Ficino: Three books on life [De vita coelitus comparanda]. Tempe AZ.

Kelley, D. H. \& Milone, E. F. (2011²), Exploring ancient skies: a survey of ancient and cultural astronomy. New York. http://dx.doi.org/10.1007/978-1-4419-7624-6

KNORR, W. R. (1990), «Plato and Eudoxus on the planetary motions», Journal for the History of Astronomy 21(4): 313-329.

Kоттек, S. S. (1994), «Appendix two: hygiene and healing among the Essenes: the testimony of Josephus», Medicine and hygiene in the works of Flavius Josephus. Leiden: 161-173.

Kroll, G., (1894), De oraculis Chaldaicis. Vratislaviae.

Lamberton, R. \& Rotroff, S. I. (1985), Birds of the Athenian agora. Princeton NJ.

LAMPE, G. (1961), A patristic Greek lexicon. Oxford.

LANG, A. (1884), «The bull-roarer: a study of the mysteries», Custom and myth. London: 26-44.

LANZI, S. (2006), «Aion, Eros e Hades nei frammenti caldaici», Kervan 3: 35-49.

LEBEDEV, A. (1996), «Pharnabazos, the diviner of Hermes: two ostraka with curse letters from Olbia», ZPE 112: 268-278.

LECLERCQ, H. (1924), «Alphabet vocalique des gnostiques», Dictionnaire d'archéologie chrétienne et de liturgie I/1. Paris: col. 1268-1288.

Lewy, H. (1978), Chaldaean Oracles and theurgy: mysticism, magic and Platonism in the later Roman Empire, nouv. éd. par M. Tardieu. Paris.

Liddell, H. G. \& Scott, R. (1996), A Greek-English lexikon, rev. and augm. by H. S. Jones with the assistance of R. McKenzie. Oxford.

Lightfoot, J. B. (1892), «The Essenes», Dissertations on the apostolic age. London: 325-407. 
LydEKKER, R. (ed.), (1894-1895), «Wrynecks: family Iyngidae», The royal natural history III. London: 567-568.

MAJERCIK, R. D. (2001), «Chaldean triads in Neoplatonic exegesis: some reconsiderations», CQ 51(1): 265-296.

- (ed. \& transl.), (1989), The Chaldean Oracles. Leiden.

Mansoor, M. \& Davies, P. (2007²), «Essenes», Encycl. Jud. VI: 510-512.

Martínez, M. (2003a), «Definiciones del concepto campo en semántica: antes y después de la lexemática de E. Coseriu», Odisea: revista de estudios ingleses 3: 101-130. http://hdl. handle.net/10835/1380

- (2003b) «Setenta años de teoría de los campos: balance provisional», RSEL 33(2): 261-314.

Mastrocinque, A. (2002), «The divinatory kit from Pergamon and Greek magic in late Antiquity», JRA 15: 173-187.

Mathews, R. H. (1898), «Bullroarers used by the Australian Aborigines», The Journal of The Anthropological Institute of Great Britain and Ireland 27: 52-60.

Mathiesen, T. J. (1999), Apollo's lyre: Greek music and music theory in Antiquity and the Middle Ages. Lincoln NE-London.

Miller, P. C. (1986), «In praise of nonsense», en A. H. Armstrong (ed.), Classical mediterranean spirituality: Egyptian, Greek, Roman. London: 481-505.

Miralles Maciá, L. (2005), «Thíassoi y syssítia esenios: la perspectiva helenística de Filón de Alejandría acerca de la organización esenia», Misceláneas de estudios árabes y hebreos: sección hebreo 54: 27-42.

Molina Moreno, F. (1998), Orfeo y la mitología de la música, tesis doctoral dirigida por A. Bernabé Pajares. Universidad Complutense de Madrid. http://eprints.ucm.es/3946

Montero, S. (2007), «La figura del auceps en el mundo romano: economía y religión», Gerión Extra 1: 265-276.

Morley, I. (2003), The evolutionary origins and archaeology of music, doctoral dissertation. Trinity Hall, Cambridge.

Morris, F. O. (1852), «Wryneck», A history of British birds II. London: 1-5.

Moser, C. (2006), Naked power: the phallus as an apotropaic symbol in the images and texts of Roman Iltaly, doctoral dissertation. University of Pennsylvania. http://repository.upenn.edu/uhf_2006/11

Moutsopoulos, E. A. (1990), «Musique et musicalité dans les Oracles chaldaïques», Kernos 3: 281-293.

Nelson, G. W. (1940), «A Greek votive iynx-wheel in Boston», AJA 44(4): 443-456.

Nock, A. D. (1927), «The lyra of Orpheus», CR 41: 169-171.

Places, É. des (éd. \& trad.), (2003), Oracles chaldaïques. Paris.

García BAZÁn, F., (trad.), (1991), Oráculos caldeos, con una selección de testimonios de Proclo, Pselo y M. Itálico; Numenio de Apamea: fragmentos y testimonios. Madrid: 9-194.

Pallejá de Bustinza, V. (trad.), (2005³), Ibn 'Arabī: Las iluminaciones de la Meca: textos escogidos. Madrid.

Panayiotou, G. (1990), «Paralipomena lexicographica Cyranidea», ICS 15(2): 295-338.

PARry, H. (1988), «Magic and the songstress: Theocritus Idyll 2», ICS 13(1): 43-55.

Paul, S. M. \& Rabinowitz, L. I. (2007²), «Cherub», Encycl. Jud. IV: 600-601. 
Perea Yébenes, S. (2000), «El sonido de la rueca/rueda ( $\rho$ ó $\mu \beta$ os) y la magia amorosa», El

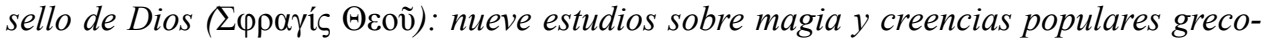
romanas. Madrid: 123-144.

- (2005) «Un capítulo de la teúrgia antigua: los oráculos de Hécate y la cuestión de las “estatuas parlantes"», Mene 5: 189-240.

Pérez-Abadín Barro, S. (2005), «El iunx o rhombus en la Farmaceutria de Quevedo», Hesperia 8: 103-116.

PERrins, C. (1987), New generation guide to the birds of Britain and Europe. Austin TX.

Picus Mirandolanus (1496), Oratio Ioannis Pici Miran. concordiae comitis. Bologna: Benedetto Faelli.

http://www.brown.edu/Departments/Italian_Studies/pico/incunab/testo/editio.html

PirenNe-Delforge, V. (1993), «L'iunge dans le discours mythique et les procédures magiques», Kernos 6: 277-289.

Poirée, E. (1901), «Chant des sept voyelles: analyse musicale», en Combarieu (ed.): 28-38.

Pokorny, J. (1959), Indogermanisches Etymologisches Wörterbuch. Bern-Munich.

Pollard, J. (1977), Birds in Greek life and myth. London.

Ragusa, G. (2004), «Afrodite, Éros e feitiçaria no Idílio 2, As magas, de Teócrito», Caliope: presença clássica 12: 18-32.

Robinson, D. M. (1927), «The discovery of a prehistoric site at Sizma», AJA 31(1): 26-50.

- (1946) «The wheel of fortune», CPh 41(4): 207-216.

Rodríguez López, M. V. \& Pérez Suescun, F. (1997), «Las sirenas medievales: aproximación literaria e iconográfica», Anales de historia del arte 7: 55-66.

Ruelle, C. (1889), «Le chant des sept voyelles grecques d'après Démétrius et les papyrus de Leyde», REG 2: 38-44.

- (1889) «Note additionnelle sur le chant des sept voyelles grecques», REG 2: 393-395.

- (1901) «Le chant gnostico-magique des sept voyelles grecques: esquisse historique», en Combarieu (ed.): 15-27.

Ruiz DE Elvira, A. (1993-1994), «La crux decussata y el martirio de San Andrés apóstol», CIF 19-20: 183-209.

SAFFrey, H.-D. (1981), «Les néoplatoniciens et les Oracles chaldaïques», REAug 27: 209-225.

Saglio, E. (1873-1919), «Rhombus», en C. Daremberg \& E. Saglio (dir.), Dictionnaire des antiquités grecques et romaines IV/2. Paris: 863-864.

SAlvatore, G. (1991), «Can archetypes be heard?», Musicworks 49: 16-21.

Santos, F. (1663), Dia, y noche de Madrid: discursos de lo más notable que en èl passa. Madrid: Pablo de Val.

Schaeffner, A. (1968), Origine des instruments de musique: introduction ethnologique à l'histoire de la musique instrumentale. Paris.

Scholem, G. (2007²), «Merkabah mysticism or Ma'aseh merkavah», Encycl. Jud. XIV: 66-67.

SEgal, C. (1973), «Simaetha and the Iunx (Theocricus, Idyll II)», QUCC 15: 32-43.

SHaw, G. (1995), Theurgy and the soul: the neoplatonism of Iamblichus. Pennsylvania.

- (2005) «The sphere and the altar of sacrifice», en R. Berchman \& J. Finamore (eds.), History of platonism: Plato redivivus. New Orleans: 147-161.

Silva, C. R. C. da (2008), Magia erótica e arte poética no Idílio 2 de Teócrito, dissertação de doutoramento sob a orientação de M. García Teijeiro e M. do C. Z. Fialho. Universidade de Coimbra. https://estudogeral.sib.uc.pt/handle/10316/7538 
Simpson, W. (1896), The Buddhist praying-wheel: a collection of material bearing upon the symbolism of the wheel and circular movements in custom and religious ritual. London.

Skolnik, F. \& Berembaum, M. (eds.), $\left(2007^{2}\right)$, Encyclopaedia Judaica. Detroit.

Souto Delibes, F. (2000), La figura de Sócrates en Jenofonte, tesis doctoral dirigida por A. Bernabé Pajares, Universidad Complutense de Madrid. http://eprints.ucm.es/4062

Stephanus, H. (1572), Thesaurus Graecae linguae. Genevae.

Tамміsто, A. (1997), Birds in mosaics: a study on the representation of birds in Hellenistic and Romano-Campanian tessellated mosaics to the early Augustan age. Rome.

TAVENNER, E. (1933), «Iynx and rhombus», TAPhA 64: 109-127.

TAYLOR, T. (1797), «Collection of Chaldean Oracles», Monthly Magazine, and British Register 3: 509-525.

- (1818) «Collection of Chaldean Oracles II», CJ 17(33): 128-133.

ThiBaut, P. J. (1901), «Assimilation des 'êchoi' byzantins et des modes latins avec les anciens tropes grecs», en Combarieu (ed.): 77-85 (= Revue d'histoire et de critique musicales 1(8): 306-314).

Thompson, D’A. W. (1895), A glossary of Greek birds. Oxford.

Touliatos, D. (1989), «Nonsense syllables in the music of the ancient Greek and Byzantine traditions», Journal of Musicology 7(2): 231-243.

TufNELl, O. (1983), «Some gold bird ornaments: falcon or wryneck?», AS 33: 57-66.

VAn Liefferinge, C. (1999), La théurgie: des Oracles chaldaïques à Proclus. Liège.

WAtson, G. E. (2002), «Birds: evidence from wall paintings, mosaics, sculpture, skeletal remains and ancient authors», en W. F. Jashemski \& F. G. Meyer (eds.), The natural history of Pompeii. Cambridge: $357-400$.

Wellesz, E. $\left(1980^{2}\right)$, A history of Byzantine music and hymnography. Oxford.

West, M. L. (1992), Ancient Greek music. Oxford.

Wood, A. (2008), Of wings and wheels: a synthetic study of the biblical cherubim. Berlin-New York. 